Andrews University

Digital Commons @ Andrews University

\title{
A Seminar on Reaching the Secular Mind for Members and Guests of the Hickory Seventh-day Adventist Church
}

Kenneth J. Ford

Andrews University

Follow this and additional works at: https://digitalcommons.andrews.edu/dmin

Part of the Practical Theology Commons

\section{Recommended Citation}

Ford, Kenneth J., "A Seminar on Reaching the Secular Mind for Members and Guests of the Hickory Seventh-day Adventist Church" (2001). Professional Dissertations DMin. 586.

https://dx.doi.org/10.32597/dmin/586

https://digitalcommons.andrews.edu/dmin/586

This Project Report is brought to you for free and open access by the Graduate Research at Digital Commons @ Andrews University. It has been accepted for inclusion in Professional Dissertations DMin by an authorized administrator of Digital Commons @ Andrews University. For more information, please contact repository@andrews.edu. 


\section{ABSTRACT}

A SEMINAR ON REACHING THE SECULAR MIND FOR MEMBERS AND GUESTS OF THE HICKORY SEVENTH-DAY ADVENTIST CHURCH

J. Kenneth Ford

Adviser: James J. North, Jr. 


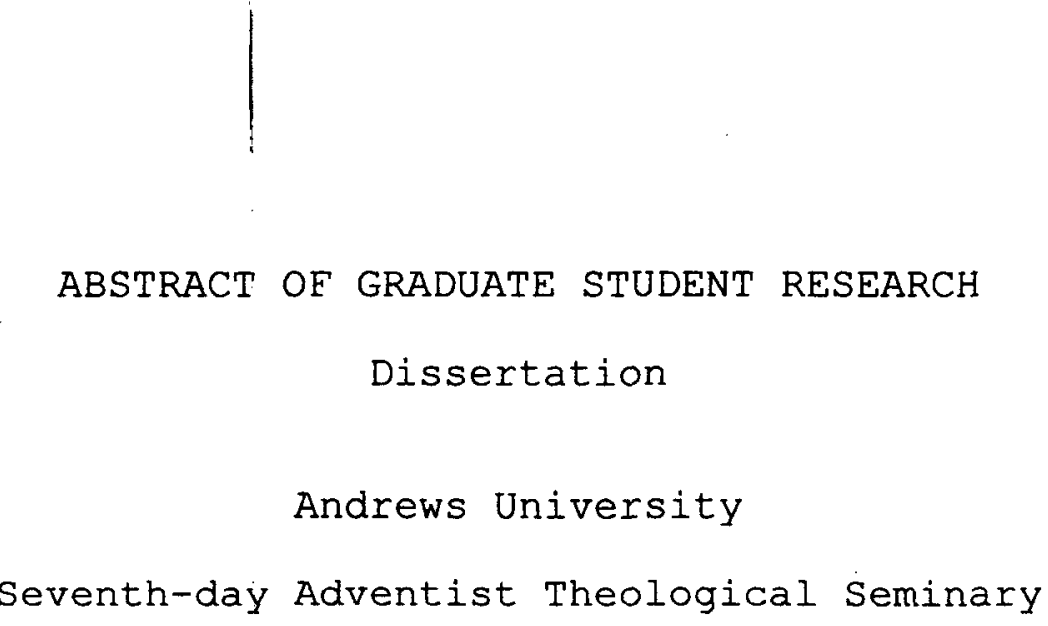

Title: A SEMINAR ON REACHING THE SECULAR MIND FOR MEMBERS AND GUESTS OF THE HICKORY SEVENTH-DAY ADVENTIST CHURCH

Name of researcher: J. Kenneth Ford

Name and degree of faculty adviser: James J. North, Jr., D.Min. Date completed: May 2001

Probiem

Western civilization is now pre- or post-Christian. Secularism has entrenched itself in our culture. Many churches are still utilizing mostly antiquated methods of reaching a Christian culture. We need to discover methods to engage the twenty-first-century secular mind.

This report is $\mid$\begin{tabular}{|c} 
Method \\
outlined in the following way. It gives
\end{tabular} its origin and development. Then it gives an overview of biblical, SDA, and selected evangelical literature on reaching the secular mind. A six-session seminar was 
formulated utilizing Microsoft PowerPoint to be conducted sometime in the near future.

\section{Results}

The results of this seminar will be determined after it is conducted. It is hoped that the material will bring about a paradigm shift in people's thinking, motivating them to be more flexible and energetic about reaching the twentyfirst-century secular mind.

\section{Conclusions}

The report shows that Scripture envisions Christians reaching all people-groups. Adventist and evangelical authors state that culturally relevant methods must be utilized to reach the secular mind. 


\begin{abstract}
Andrews University
Seventh-day Adventist Theological Seminary
\end{abstract}

A SEMINAR ON REACHING THE SECULAR MIND FOR MEMBERS AND GUESTS OF THE HICKORY

SEVENTH-DAY ADVENTIST CHURCH

\author{
A Dissertation \\ Presented in Partial Fulfillment \\ of the Requirements for the Degree \\ Doctor of Ministry
}

by

J. Kenneth Ford

May 2001 

A SEMINAR ON REACHING THE SECULAR MIND

FOR MEMBERS AND GUESTS OF THE

HICKORY SEVENTH-DAY ADVENTIST CHURCH

A dissertation

presented in partial fulfillment

of the requirements for the degree

Doctor of Ministry

by

J. Kenneth Ford

APPROVAL BY THE COMMITTEE:
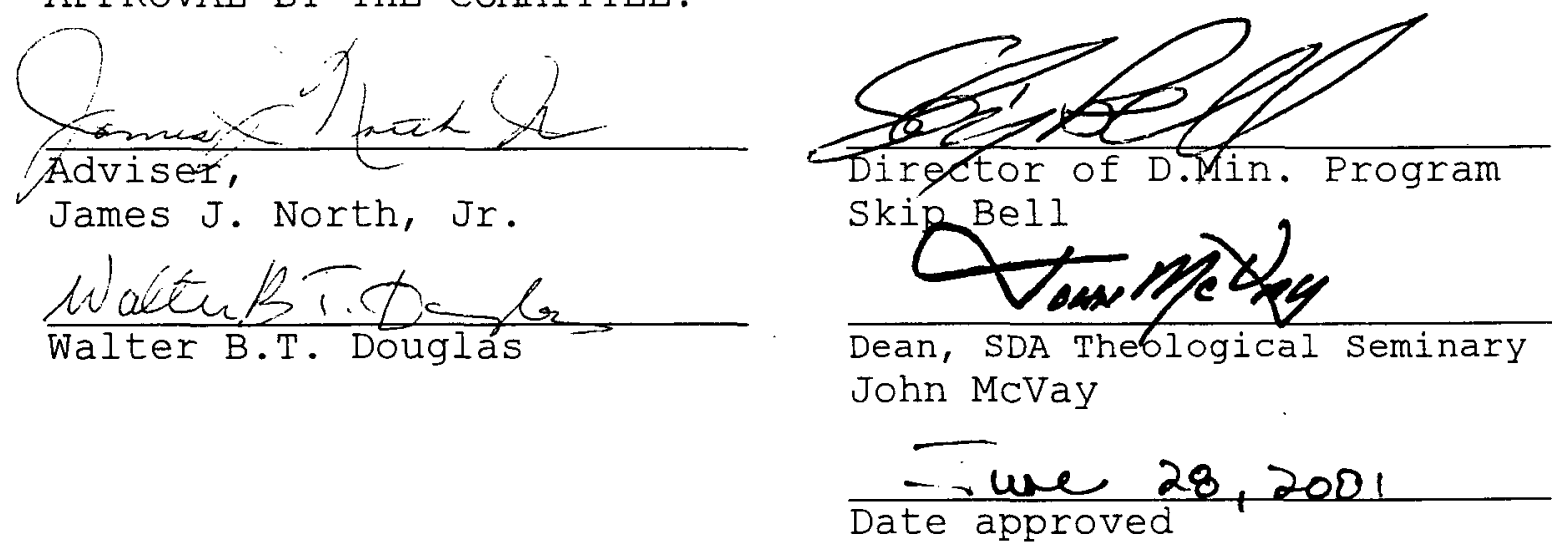
TABLE OF CONTENTS

LIST OF TABLES

$\mathrm{V}$

Chapter

I. INTRODUCTION . . . . . . . . . . . . . . . . . . . 1

Purpose . . . . . . . . . . . . . . . . 1

Justification . . . . . . . . . . . . . . . . I

Organization . . . . . . . . . . . . . . . . . 2

Expectations . . . . . . . . . . . . . . . 4 4

Limitations . . . . . . . . . . . . . 5

II. A BRIEF OVERVIEW OF SECULARISM . . . . . . . . . 6

Defining Secularism . . . . . . . . . . 6 Jon Paulien . . . . . . . . . . . . . 6

Committee on Secularism . . . . . . . 8

Mark Finley . . . . . . . . . . . . . . . . 8

George G. Hunter III. . . . . . . . . . 10

Origin and Development of Secularism . . . . 13

Gottfried Oosterwal . . . . . . . . . 16

Jon Paulien .............. . 20

George Hunter III . . . . . . . . . . 22

Timothy Phillips and Dennis Okholm . . . 26

William Easum . . . . . . . . . . 26

Secularism in the SDA Church . . . . . 28

III. AN OVERVIEW OF BIBLICAL AND SDA IITERATURE

ON REACHING THE SECULAR MIND . . . . . . . . 30

Biblical Literature . . . . . . . . 30

God Wants Us to Reach All People-Groups . 30

Preach Christ . . . . . . . . . . . . 32

Address Practical Human Needs . . . . . 34

Selected Parables of Jesus . . . . . . 35

The lost sheep, coin, son... . . 36

The sower... . . . . . . . . . 36

Fishing for Jesus. . . . . . . . . 37

Cloth and wineskins. . . . . . . 38 
Selected Interviews of Jesus . . . . . 39

Nicodemus . . . . . . . . . . . 39

The Samaritan woman . . . . . . 39

The Rich Young Ruler ......... 40

Selected Passages on Methodology . . . 41

SDA Literature .. . . . . . . . . . . . 45

Ellen White ............. . 45

Marketing the gospel :. . . . . . 45

Meeting people's needs . . . . . . 50

Reaching out to the worldly person . 53

Speak of Christ .. . . . . . . . 53

Do not repeat falsehoods . . . . . 54

Work one-on-one .......... 54

Public worship services... . . . 55

In balance .. . . . . . . . . . 56

Jon Paulien ............. . 59

Monte Sahlin ............ . 65

Ken Cox .............. 69

Mark Finley . . . . . . . . . . 71

Daniel G. Matthews . . . . . . 72

Dan Day . . . . . . . . . . . . 75

Bert B. Beach ........... 78

John W. Fowler ........... . 79

J. David Newman . . . . . . . . 82

Reinder Bruinsma . . . . . . . . 83

Bruce Campbell Moyer . . . . . . . 84

IV. AN OVERVIEW OF SELECTED EVANGELICAL

LITERATURE ON REACHING THE SECULAR MIND . . . . 86

George G. Hunter III . . . . . . . . 86

Bill Hybels . . . . . . . . . . . . . 96

Lee Strobel . . . . . . . . . . . . 97

Leith Anderson. . . . . . . . . . 105

George Barna . . . . . . . . . . . 111

William M. Easum . . . . . . . . . 116

V. EVALUATION AND SYNTHESIS OF MATERIAL . . . . . 124

Chapter 2 ............... 124

Chapter 3............... . 127

Chapter 4 . . . . . . . . . . . . . . . 135

Conclusions ............ . . 142

APPENDIX . . . . . . . . . . . . . . . . 144

BIBLIOGRAPHY . . . . . . . . . . . . . . 249 


\section{LIST OF TABLES}

1. Secular vs. Religious People . . . . . . . . . 7

2. Christianity vs. Secularism . . . . . . . . . . 9

3. The Process of Becoming a Committed Christian . . . 70 


\section{CHAPTER ONE}

\section{INTRODUCTION}

\section{Purpose}

The purpose of this project was to develop a seminar for the Hickory Seventh-day Adventist (SDA) church in Hickory, North Carolina, on how to reach the secular mind as part of fulfilling Christ's directive for world-wide evangelism.

\section{Justification}

Western society is now pre- or post-Christian, that is, we act as if we have never heard of Christ, or we intentionally ignore Him. Christianity does not have the "home playing field advantage" anymore. Some people groups have little knowledge of Christ's gospel, not even knowing of the Beatitudes or His parables.

Everything happens by cause and effect, events are not explained as supernatural interventions. People do not depend on God's guidance, everything is relative. This life is all there is.

Secularism has entrenched itself in the culture. It 
unwittingly colors the way many people, both churched and unchurched, look at reality. People's priorities, values, and felt needs are significantly impacted by this mind-set. People today are focused on present needs and problems. They want a better quality of life today. They want life before death.

The computer technological information age has depersonalized society. Many people spend hours each day in front of a computer monitor, while spending only minutes communicating with each other.

Many churches in the early 2000 s are ignoring the influence of secularism by utilizing many antiquated methods of communicating with their culture. Television is a major conveyer of secularism, using fast-paced multimedia that grip the attention.

Methods that consider the impact of secularism need to be utilized in internal programming as well as in evangelism.

\section{Organization}

This report is divided into five chapters. Chapter 1 , the Introduction, presents the purpose and justification for the project, the organization of the material, and its limitations.

Chapter 2 provides a brief overview of secularism. It 
gives a concise definition of secularism, then describes its many facets. The origin and development of secularism are covered next. The chapter closes by discussing the impact of secularism in the SDA church.

Chapter 3 furnishes an overview of biblical and SDA literature on reaching the secular mind. Peter's vision of the sheet, selected parables and interviews of Jesus, and several passages on methodology are covered next.

Ellen White's pointers are synthesized in seven areas:

(1) marketing the gospel, (2) meeting people's needs,

speaking of Christ, (4) not repeating falsehoods, (5)

working one-on-one, (6) public worship services, and (7) keeping everything in balance.

Recommendations from seven SDAs end the section: (1)

Jon Paulien, (2) Monte Sahlin, (3) Ken Cox, (4) Mark Finley, (5) Dan Matthews, (6) Dan Day, and (7) Bert Beach. Chapter 4 is an overview of selected evangelical literature on reaching the secular mind. Eleven individuals are cited: (1) George Hunter III, (2) William Easum, (3) Bill Hybels, (4) Lee Strobel, (5) Rick Warren, (6) Leith Anderson, (7) Lynn Anderson, (8) Jeff Woods, (9) Alan Klaas), (10) Stanley Hauerwas, and (11) George Barna. Chapter 5 offers evaluation and synthesis of the material.

The Appendix contains the Microsoft PowerPoint seminar 
to be given at the Hickory SDA Church.

\section{Expectations}

My experience of twenty-five years in pastoral ministry and the experience of others with whom I am associated indicate that many church members are unaware of the effects of secularism on themselves and other persons. They tend to believe that the proclamation model, where the speaker merely announces truth without reference to peoples' mindset and felt needs, is the biblical model. They do not want to market the gospel, they wish to merely present it. They do not perceive the need to package the gospel in a way most likely to be received.

It is hoped that this report will educate members of the Hickory SDA church to understand and be aware of the impact of secularism on themselves and the world at large.

Furthermore, it is hoped that the result will be a desire to more effectively reach the secular mind in the Hickory. community.

I plan to discuss this seminar with the leadership of the Carolina Conference of SDAs and offer to share its findings at workers' meetings and camp meetings.

I plan to write and submit a book for publication utilizing the information from this research and seminar. 


\section{Iimitations}

The report does not attempt to decide if secularism is pre- or post-Christian. Several authors have discussed the merits of both positions.

Chapter 2 is not meant to be an exhaustive historical exposition of secularism. It provides a brief definition and description of secularism, and an overview of the major way marks in the secularizing of Western culture.

This report was prepared when post-modernism was not an issue. A post-modern person experiences life rather than merely looking at life rationally. Feeling has a much greater place than logic. When I conduct the seminar, I will include a section on post-modernism and its impact on secularism. 
CHAPTER TWO

\section{A BRIEF OVERVIEW OF SECULARISM}

\section{Defining Secularism}

Secularism has been defined as religious skepticism or indifference. ${ }^{1}$ It is difficult to define secularism in a sentence or two, hence various descriptions follow.

\section{Jon Paulien}

In the chapter "Defining the Secular," Paulien provides a chart (see table 1) that suggests the differences between the secular person and the religious. The secular person is described in the left column, the religious one on the right. Statistically, there are more secular males than females, etc.

${ }^{1}$ American Heritage Dictionary of the English Language, 3d ed. (1992), s.v. "secularism." 
TABLE 1

SECULAR VS. RELIGIOUS PEOPLE

\begin{tabular}{|l|l|}
\hline \multicolumn{1}{|c|}{ Secular } & \multicolumn{1}{c|}{ Religious } \\
\hline Male & Female \\
\hline Young & Old \\
\hline Urban & Rural \\
\hline More educated & Less educated \\
\hline Rich & Poor \\
\hline Mobile & Stationary \\
\hline Public & Secluded \\
\hline Industrial & Agricultural \\
\hline Informational & Manufacturing \\
\hline
\end{tabular}

Source: Jon Paulien, Present Truth in the Real World (Boise: Pacific Press, 1993), 51.

Secular people think in terms of contingency. Everything happens by cause and effect; no event can be explained in terms of supernatural intervention.

Secular-minded people are autonomous and independent in the sense that they tend not to feel any need for God's guidance in their lives. Meaning, values, and truth depend on the situation. Everything is relative. What is right in one situation may be wrong in another. There are no objective morals and principles that could control the development of society. What matters is usefulness-"Does it work?"

This life is all there is. The afterlife is considered 
only wishful thinking, useful for those who cannot face the fears and anxieties related to death and dying.

Secular people are not atheists. They may believe in God, yet may not be continually conscious of God's involvement in the day-to-day life. ${ }^{1}$

\section{Committee on Secularism}

On June 11, 1981, the General Conference Committee of the SDA Church appointed a "Committee on Secularism." Selected papers were collected and bound in the book Meeting the Secular Mind: Some Adventist Perspectives. In the Epilogue, the committee presented a chart (see table 2) that distinguishes biblical Christianity from humanistic secularism.

\section{Mark Finley}

Finley is currently the speaker/director for It Is Written. Finley portrays four basic types of secularists:

1. The "secular materialists" chief interests are economics, money, and possessions.

2. The "religious dropouts" were brought up in a religious home, but are turned off with organized religion. They want peace, on their own terms. They consider social and philosophical issues.

${ }^{1}$ Jon Paulien, Present Truth in the Real World (Boise: Pacific Press, 1993), 43-47. 
TABLE 2

CHRISTIANITY VS. SECULARISM

\begin{tabular}{|l|l|l|}
\hline Understanding of & $\begin{array}{l}\text { Biblical } \\
\text { Christianity }\end{array}$ & $\begin{array}{l}\text { Bumanistic } \\
\text { Secularism }\end{array}$ \\
\hline Prime reality & Personal God & $\begin{array}{l}\text { Inanimate matter } \\
\text { and energy }\end{array}$ \\
\hline $\begin{array}{l}\text { Origin of universe } \\
\text { and life }\end{array}$ & Created by God & $\begin{array}{l}\text { Cause and effect; } \\
\text { chance }\end{array}$ \\
\hline Nature of humanity & $\begin{array}{l}\text { Physical-spiritual } \\
\text { being, in God's } \\
\text { image }\end{array}$ & $\begin{array}{l}\text { Phase in natural } \\
\text { evolution }\end{array}$ \\
\hline Meaning of life & $\begin{array}{l}\text { Preparation, } \\
\text { service, } \\
\text { fulfillment }\end{array}$ & Uncertain, unknown \\
\hline Basis of morality & $\begin{array}{l}\text { Eternal character } \\
\text { of God }\end{array}$ & Contemporary mores \\
\hline Human condition & Sinful, changing & $\begin{array}{l}\text { Imperfect, } \\
\text { changing }\end{array}$ \\
\hline $\begin{array}{l}\text { Means of } \\
\text { improvement }\end{array}$ & Spiritual rebirth & $\begin{array}{l}\text { Human planning and } \\
\text { effort }\end{array}$ \\
\hline Death & Parenthesis & End of everything \\
\hline Human history & $\begin{array}{l}\text { God-influenced, } \\
\text { purposeful }\end{array}$ & $\begin{array}{l}\text { Human-controlled, } \\
\text { puzzling }\end{array}$ \\
\hline Human destiny & $\begin{array}{l}\text { New being through } \\
\text { God's redemption }\end{array}$ & Nothingness \\
\hline
\end{tabular}

Source: Humberto Rasi and Fritz Guy, eds., Meeting the Secular Mind: Some Adventist Perspectives (Berrien Springs: Andrews University Press, 1985), 183. 
3. The "hard hats" are the tough all-Americans who work from sunup to sundown. They do not want to be bothered with religion, they are too busy working. They are not obsessed with possessions and are not philosophers, but are just good family people.

4. And finally, the "secular philosophers" are introspective and thoughtful. They reject Christianity as a viable option, turned off by those who quote Scripture as authoritative. They prefer a naturalistic world view. Darwin and Freud are accepted as truth. The world came into existence through randomness, and people are merely products of their environment and heredity. ${ }^{1}$

And now we turn to a non-SDAs' definition of secularism, George G. Hunter III.

\section{George G. Hunter III}

Hunter is currently Dean at the E. Stanley Jones School of Evangelism and World Mission at Asbury Theological Seminary. He posits ten characteristics of secular people:

1. Secular people are essentially ignorant of basic Christianity. They may not know, for example, about the Lord's Prayer, the Beatitudes, the old and New Testaments,

${ }^{1}$ Mark Finley, "Target and Tactics," in Meeting the Secular Mind: Some Adventist Perspectives, ed. H. Rasi and F. Guy (Berrien Springs: Andrews University Press, 1985), 101-102. 
biblical stories in general.

2. Secular people are seeking life before death. They do not focus on the heavenly reward, they want a better life now. In contrast to the "death orientation" that characterized Western peoples until fairly recent times, most secular people today are "life oriented." The very motive for evangelism must now change. Once, when the population feared death and hell, the appeal of life after death motivated the Christian mission. Christian religion used to be related to life after death; now it must be related to the quality of life here and now.

3. Secular people are conscious of doubt more than guilt. Doubt replaces guilt as the number one factor in the secular audience. In Christian societies, until fairly recent times, the non-Christian felt a profound sense of guilt. This feeling has almost disappeared.

4. Secular people have a negative image of the Church. They doubt the intelligence, relevance, and credibility of the Church and its advocates. They still place more confidence in science and common sense than in religion. The doubts regarding the church's relevance began when the Church reacted defensively to the events of secularism. Most people do not differentiate between their feelings about Church and about God.

5. Secular people have multiple alienations. These 
would include alienation from nature (sport killing, strip mining, endangered species, ecological crisis), from neighbors (high-rise apartments, etc.), and from political and economic systems upon which their lives depend, as evidenced from the breakdown of lifetime job security. Others would include alienation from their vocations, as evidenced by their expressed lack of meaning in their life work and their obsession with leisure pursuits. In Christendom, it seems that people were secure and felt included, and their need "to belong" was essentially met through their work, extended family, and village life. ${ }^{1}$

6. Secular people are untrusting. Schuller believes that it is more useful to relate to a non-Christian as a non-trusting person, i.e., fearful and suspicious, than to relate to him or her as an evil or depraved or shameful soul.

7. Secular people have low self-esteem. They say, "I'm not what I think I am; I'm not what you think I am; I am what I think you think I am."

8. Secular people experience forces in history as "out of control." They face the future with great anxiety.

9. Secular people experience forces in their personal lives as "out of control." Forces in their own

\footnotetext{
${ }^{1}$ We assume here that church life is included, although the author does not list it.
} 
personalities and families that they cannot control would include such things as addictions and substance abuse.

10. Secular people cannot find "the door" to God."

He also suggests three types of secularity: utter, mere, and controlled:

1. "Utter Secularity" portrays a formal and unrelenting attack on gods and churches. Voltaire and Marx are examples.

2. "Mere Secularity" ignores God. People are preoccupied with this world and their daily routines. This kind of secularity retains the shell of Christianity, e.g., churches, parochial schools, religious coronation of the monarch, a state church. Yet there is little meaning, power, or commitment in religion.

3. In "Controlled Secularity," religion deifies traditional American values. ${ }^{2}$

\section{Origin and Development of Secularism}

In the biblical (OT) and patristic ${ }^{3}$ periods, nature was seen as governed by laws administered by God. However, Greek science has had a profound influence on human thought. Some Jews adopted a receptive attitude towards the dominant

${ }^{1}$ George G. Hunter III, How to Reach Secular People (Nashville: Abingdon Press, 1992), 43-54.

${ }^{2}$ Ibid., 31-32.

${ }^{3}$ Christian period before $8^{\text {th }}$ century A.D. 
Greek culture during intertestamental Judaism. Other more conservative Jews reacted strongly against the process of Hellenization ( 1 Macc 1:11-15; 2 Macc 4:4-17).

Christians in the second and third centuries faced a similar dilemma (Should a person follow reason or revelation?). Some, for example, Justin Martyr (b. ca. A.D. 165), "borrowed the Stoic idea of a seminal Word (Iogos spermatikos) implanted by God in all humans and maintained that this seed inspired the best philosophy of the Greeks as well as the prophecies of the old Testament." Others such as Irenaeus (b. ca. A.D. 120/140) and Tertullian (b. ca. A.D. 155/160) were more critical of Greek philosophy. Irenaeus called natural philosophers' teachings "a heap of miserable rags."

During the Middle Ages, ${ }^{2}$ religious persons tended to belittle human affairs. They believed meditation on God and the afterlife was the business of life. A sharp distinction arose between the absolute power of God and the normal course of nature in the twelfth and thirteenth centuries,

${ }^{1}$ Christopher Kaiser, Creation and the History of Science (Grand Rapids: Eerdmans, 1991), 3.

${ }^{2}$ The Middle Ages started with the collapse of Roman Civilization in the $5^{\text {th }}$ century A.D. and ended with the Renaissance in the $13^{\text {th }}, 14^{\text {th }}$, or $15^{\text {th }}$ century, depending on the region of Europe. 
somewhat in reaction to naturalistic ${ }^{1}$ science. This period of rebirth, the Renaissance, ${ }^{2}$ immediately followed the Middles Ages with such philosophers as Marsilio Ficino and Nicolo Machiavelli. The influence of the Italian humanists and their search for a more rational basis for viewing and integrating reality rises in this period.

There was a new awareness of the individual coupled with an awakened interest in the material world and nature. Copernicus (b. ca. A.D. 1473) discovered that the earth was not the center of the universe; ${ }^{3}$ Newton (b. Ca. A.D. 1642) looked at an apple fall and postulated gravity. Humanism ${ }^{4}$ made humanity the measure of all things. The dignity of humanity and mastery of nature replaced the medieval ideal of a life of penance. Cultural achievements and personal fulfillment in this world became paramount. Human values eclipsed religious belief. Fundamental knowledge became

${ }^{1}$ Naturalism is a system of thought holding that all phenomena can be explained by natural causes and laws. Supernatural causes are denied. Nature, not revelation, is truth.

2The Renaissance period is roughly the $14^{\text {th }}$ through the $16^{\text {th }}$ centuries, marking the transition from medieval to modern times.

${ }^{3}$ Kaiser, 98 .

${ }^{4}$ Humanism places central emphasis on the human realm. Encyclopaedia Britannica, 1998 ed., s.v. "humanism." Individual values as opposed to religious belief are paramount. Grolier Encyclopedia, 1998 ed., s.v. "humanism." Humanism started during the Renaissance. 
based on reason and rational analysis of ideas, not the church. People shied away from otherworldliness to life on earth. This became known as "the enlightenment."1 Indeed it was the seventeenth century that gave rise to the movement that was named the "age of rationalism." The influence of rationalism was the beginning of modernity in which secularism was viewed as the new Messiah that would solve all problems. Rationalism would make life better. Reality was primarily objective. This was a radical shift in people's understanding of knowledge.

Humanism gave rise to outright secularism, where otherworldliness is secondary at best and outright ignored at worst. People are taught to focus on this earth, this Iife, the here and now. This brought about the collapse of the old Aristotelian world view and the dawning of the modern age.

We will now look first at two SDA and then three nonSDA theologians prominent in writing on the origin and development of secularism.

\section{Gottfried Oosterwal}

Oosterwal, former director of the Institute of World Mission at Andrews University, suggests that becoming

${ }^{2}$ The Enlightenment was an $18^{\text {th }}$-century movement that stressed reason over and above acceptance of tradition and accepted doctrines. 
secular is universal, inevitable, and irreversible. It is not merely "de-Christianization" or "becoming unchurched." It affects people and societies and religions everywhere. It is the most compelling agent molding our history. Although the effects of secularism are a fairly recent sensation, the process itself extends far back into history. ${ }^{1}$

Oosterwal uses Harvard theologian Harvey Cox's three stages in the process of secularization: ${ }^{2}$

1. In the tribal stage, life centers in groups, mainly in family (kinship) and the village community. Habitual face-to-face relationships typify this stage. Traditions are strong, relationships deep and enduring, people's norms and values are created and molded by religion. Religion is the essence of life and defines all thinking and behavior.

2. In the town stage, the limiting boundaries of kinship are jettisoned for less isolated, more open local communities. Specialization, differentiation, and a more rational orientation to life are prevalent. The social life and economic system are firmly grounded in a small, local

${ }^{1}$ Gottfried Oosterwal, "The Process of Secularization," in Meeting the Secular Mind: Some Adventist Perspectives, ed. H. Rasi and F. Guy (Berrien Springs: Andrews University Press, 1985), 45-49. Oosterwal uses the word "secularization." Other authors talk of "becoming secular." I use these terms interchangeably in this report.

$$
{ }^{2} \text { Ibid. , 52-53. }
$$


populace.

Religion becomes systematized, organized, and institutionalized in the town stage. It is differentiated from other spheres of life now. Churches and theologies emerge. Religion is still the primary controlling structure which gives meaning, potency, identity, and stability to Iife.

3. The final stage, technopolis, describes the modern urban society. Commercial production, sale of goods, and manufacturing begin to appear. Large masses of people living in close proximity become a reality. Oosterwal continues quoting Cox in describing the four traits of Technopolis:

a. Contingency: Everything that is, was caused by some natural phenomena that preceded it. This concept has no place for God as the Creator; no religious explanations are sought.

b. Autonomy: Humanity is the creator of its own environment and its own destiny, accountable to no one else but oneself.

c. Temporality: All things and all of life are limited by time and space. There is no afterlife, no future world, and hence no lasting significance to human thoughts or actions. Death is the end of everything. 
d. Relativity: In the world created by humanity there are no absolute norms binding for all people at all times. All norms are relative to the society, to the culture, and even to the individuals who are affected by them. ${ }^{1}$

In this technopolis, says Cox, religion and church as we know them cease to function. Theology loses its position and becomes obsolete. And the traditional roles of the minister and priest are taken over by non-religious specialists.

This change from a group-oriented, close-knit rural community, based on an agrarian economy and rooted in traditions and transcendent values, to an open and pluralistic urban-industrial society, constitutes the process (almost certainly irreversible) in which belief in the supernatural is disappearing, life and existence are losing their sacrality, religious values are being discarded and practices given up, religious institutions are declining, and the church's influence and authority are being eroded. ${ }^{2}$

Oosterwal suggests that secularization is so complex and ambiguous that simple definitions do not suffice, yet he posits six characteristics of the process of secularization:

1. The decline of religion as a factor shaping human life and thought and behavior.

2. The desacralization of life.

3. The change from a community-oriented way of life to one which is based on a societal system, with its pluralism and privatism, its specialization and differentiation, its impersonal technical

\footnotetext{
${ }^{1}$ Ibid., 53-54.

${ }^{2}$ Ibid., $54-55$.
} 
4. The loss of faith.

5. The development of a particular way of thinking, of a new mood and mentality, characterized by rationalism and relativism, pragmatism and positivism, empiricism and existentialism.

6. Conformity with the world, expressed in religious people's and organizations' acceptance of and adaption to contemporary social and cultural values. ${ }^{1}$

The dominant values in American society, such as individualism, personal achievement, material success, democracy, freedom, and the pursuit of happiness, are clearly non-religious and are a direct consequence of secularism.

\section{Jon Paulien}

Paulien is a professor of New Testament at the Seventhday Adventist Theological Seminary. He suggests that three major influences drive secularism. Science is first and foremost. Decisions are made on the basis of science and the scientific method, as opposed to consulting a Higher Power. We observe a situation, talk with other people who have experienced a similar situation, and finally formulate all the data and make a decision. Prayer is not the first step in this scenario. In fact, we act as if God does not exist. Many natural phenomena can be explained in natural terms.

Pluralism, many religious persuasions receiving equal

$$
{ }^{1} \text { Ibid. , } 42 .
$$


attention, is a second force. No one religion is exclusively the right one.

Privatization, the third influence, deems it inappropriate to discuss religion in the public arena. The church ceases to dominate society; it is merely one voice among many. Faith is moved into the closet, irrelevant to everyday life. Secularization destroys faith as it makes truth relative or irrelevant. The church no longer occupies center stage. ${ }^{1}$

North Americans have become secularized. There is an erosion of belief in the supernatural; cause and effect are limited to this world. Religion is practically irrelevant to a person's life; many forms of faith and worship are rejected. ${ }^{2}$

One's response to secularism can be in three forms: escape into the present, escape into a group that separates from the world, or plunge into the world as it is. ${ }^{3}$

Now, let us look at non-SDA authors' material on the origin and development of secularism.

${ }^{1}$ Paulien, Present Truth in the Real World, 53-60.

"Jon K. Paulien, "The Gospel in a Secular World," in Meeting the Secular Mind: Some Adventist Perspectives, ed. Humberto M. Rasi and Fritz Guy (Berrien Springs: Andrews University Press, 1985), 27.

${ }^{3}$ Paulien, Present Truth in the Real World, 59. 


\section{George Hunter III}

Hunter writes a chapter about "How the West Was Lost." Christianity picked up the pieces of a fallen Roman Empire. Christianity created a new civilization, shaped laws according to biblical teaching, and placed monarchs under Christian ecclesiastical authority. The Church decided what was "good" government, education, art, architecture, literature, music, personal morality, community life, and even economics. It monopolized human reasoning. Worldlings thought all Western people were "Christians." This reality lasted for centuries. ${ }^{1}$

Hunter describes six pivotal events that caused the ebbing of Christendom and secularization of the West: ${ }^{2}$

1. Secularization began with the Renaissance, an intellectual and cultural movement from the mid-fourteenth century to the early sixteenth century, led by Erasmus and Bacon. Essentially, the Renaissance represents the West's rediscovery of ancient Greek philosophy, science, and literature. The Renaissance affected Western people in three ways:

a. First, it redirected people's attention from God, another world, and theological matters to this world, to humans, and to humanity's progress. The

${ }^{1}$ Hunter, How to Reach Secular People, 23-24.

${ }^{2}$ Ibid. , 26-29. 
battle cry of the Renaissance was the Greek sophist Protagoras's statement: Man is the measure of all things .

b. Second, the Church's world view was, for centuries, the only comprehensive world view available to Europeans. But the recovery of Greek philosophy gave people another option for understanding life and the world, thereby introducing pluralism and a new source of doubt to Western minds.

c. Third, the Renaissance created the cultural soil out of which humanism eventually emerged as a major and perennial competitor to Christian truth claims and ethics.

2. The breakup of Christendom continued with the Protestant Reformation (sixteenth century). The Reformation removed Church influence from Western life by dividing the Church and by turning the Church's attention away from the management of society and inward toward renewal, reorganization, and theological matters.

3. Secularization continued with the rise of Nationalism (started $17^{\text {th }}$ and $18^{\text {th }}$ centuries) and the rise of proud independent nations in what had once been a comparatively united Europe. The nationalistic spirit undercut the understanding of a common humanity that had largely prevailed in Christendom. Moreover, nationalism led 
to unprecedented warfare between the peoples of Europe-including the two world wars of the last century.

4. The rise of Science challenged Christendom's prescientific assumptions about the universe and human life.

5. The Enlightenment built upon the Renaissance to escalate the West's secularization. It spawned enormous confidence in human reason. Natural religion grew. Morality and society could be based on reason alone, without revelation or religion. It trumpeted "human dignity" and "human rights" and inspired movements working for a more just and humane society, thereby providing a radical alternative to Christian teachings and Christian service.

6. If the Enlightenment escalated the secularization process, Urbanization stampeded it. The United States population has moved from 20 percent urban in 1870 , to 40 percent in 1900, to 70 percent by 1980, and approached 90 percent urban in A.D. 2000. Urbanization is the Siamese twin of secularization. ${ }^{1}$

Hunter says "The Enlightenment's teachings are more widely believed by more Western people than are the teachings of Christianity." ${ }^{2}$ As more and more scientific answers were provided for observable phenomena, many Western

${ }^{1}$ Ibid.

${ }^{2}$ George G. Hunter III, Church for the Unchurched (Nashville: Abingdon Press, 1996), 21. 
people ceased to expect miracles; the supernatural became optional.

Many Christians today have awakened up to the reality that it is no longer "our world."1 Anderson suggests that we are experiencing the demise of the Constantinian (i.e., "the empire is all Christian") world view. In talking of America as part of the West, he reflects that it is no longer a Christian nation; it is a secular mission field. ${ }^{2}$

The church must understand today's culture in order to benefit today's people. ${ }^{3}$ We must study sociology interfaced with theology. We must understand our post-modern, secular world. ${ }^{4}$

Hunter suggests that Christianity's influence upon Western people was further eroded by its pathological pattern of responses to the above events. Her credibility was diminished, thereby distancing the people from her witness. For instance, the Church tried to control scientific research. It prohibited Leonardo's study of

${ }^{1}$ Stanley Hauerwas and William $\mathrm{H}$. Willimon, Resident Aliens: Life in the Christian Colony (Nashville: Abingdon Press, 1989), 17-18.

${ }^{2}$ Leith Anderson, A Church for the $21^{\text {st }}$ Century (Minneapolis: Bethany House Publishers, 1992), 150.

${ }^{3}$ Leith Anderson, Dying for Change (Minneapolis: Bethany House Publishers, 1990), 17.

${ }^{4}$ William Easum, Dancing with Dinosaurs: Ministry in a Hostile and Hurting World (Nashville: Abingdon Press, 1993), 113-114. 
cadavers to understand human anatomy and Copernicus's books for 200 years. ${ }^{1}$

\section{Timothy Phillips and Dennis Okholm}

Phillips and Okholm edited the book Christian

Apologetics in the Postmodern World. In their Introduction, they talk of the secularization of the church:

Pluralism and pragmatism have secularized the church; mainliners seek cultural respectability and political correctness, while marketers seek popularity. We are becoming secularized by the culture we are trying to reach with the gospel, and in this respect mainliners and evangelicals look alike. Mainline Protestantism offers a highly politicized ethic controlled by the dictates of enlightened secular culture, while market-driven evangelicalism offers a psychologized gospel conditioned by self-control, consumer-oriented, media-induced felt needs. . . The church itself is in need of evangelization, since it has been heavily influenced by radical pluralism, individualism and relativism. ${ }^{2}$

\section{William Easum}

Easum is the Director of $21^{\text {st }}$ Century Strategies. He travels over 300 days each year as a full-time consultant to both churches and businesses, specializing in portraying effective strategies for reaching secular people. His book, Dancing with Dinosaurs, pictures Christian traditions as "dinosaurs." Twelve assumptions form a filter for the ideas

${ }^{1}$ Ibid. , 29.

${ }^{2}$ Timothy R. Phillips and Dennis L. Okholm, eds., Christian Apologetics in the Postmodern World (Downers Grove: InterVarsity Press, 1995), 22-23. 
in his book:

1. North America is the new mission field.

2. Society will become increasingly hostile toward Christianity in the twenty-first century.

3. The distinction between clergy and laity will disappear in the twenty-first century.

4. If churches only improve what they have been doing, they will die.

5. The best way to fail today is to improve yesterday's successes.

6. Bureaucracies and traditional practices are the major causes of the decline of most denominations in North America.

7. Traditional churches that thrive in the twentyfirst century will initiate radical changes before the year 2001 .

8. God exists and creates everything.

9. Jesus Christ is the center of all human life.

10. The Bible is our primary source of faith and practice.

11. The purpose of the Body of Christ is to bring the world to faith in Jesus Christ.

12. A way will be found to avoid world ecological and economic disaster. ${ }^{1}$

The world "is becoming culturally and racially diverse and unchurched."2 North America is changing; century-held trusted values are vanishing, never to be seen again. ${ }^{3}$ We are the first generation of immigrant North Americans "to live in a society that no longer appreciates the presence of Christianity."4 Among the sixteen paradigm shifts occurring during this period (A.D. 1960-2014) is a transition from a

${ }^{1}$ Easum, Dancing with Dinosaurs, $13-14$.

${ }^{2}$ Ibid., 15 .

${ }^{3}$ Easum synthesizes Alvin Toffler, Powershift: Knowledge, wealth, and Violence at the Edge of the $21^{\text {st }}$ Century (New York: Bantam Books, 1990), xix.

${ }^{4}$ Easum, Dancing with Dinosaurs, 45 . 
"churched" to an "unchurched" society. ${ }^{1}$

In this new emerging world the process of secularization will increasingly distance itself from any religious worldview. The media may increasingly treat Christianity and other faiths as irrelevant. Its god, technology, is more promising. ${ }^{2}$

\section{Secularism in the SDA Church}

Paulien suggests six ways in which SDAs become secular:

1. The first step in the process of secular drift occurs in the private prayer life. In its very secrecy, private prayer is the ultimate personal barometer of spiritual commitment. Prayer is often the first thing to go.

2. The next area affected is usually the study life. While Bible study may continue in the absence of prayer, it tends to have decreasing personal significance.

3. In the third step, personal standards of behavior begin to erode.

4. People begin to attend church less.

5. They begin to doubt the Bible itself.

6. In the final step, there is an increasing distrust

${ }^{1}$ Gerald Celente, Trend Tracking (New York: John Wiley and Sons, 1990), 11-18.

${ }^{2}$ Easum, Dancing with Dinosaurs, 25-26. 
of institutions. ${ }^{1}$

The SDA Committee on Secularism believed that the SDA church had felt in varying degrees the effects of secularization: success orientation as opposed to a servant church, self-preoccupation instead of self-sacrifice, and passive-spectator mind-set instead of active involvement started the list. Elitism instead of Christian community, competition instead of cooperation, and corporate managerial style as opposed to contribution of the whole body were added to the list. And finally, striving for affluence instead of biblical stewardship, ethnocentrism as opposed to oneness in Christ, and acceptance of the end justifying the means instead of following biblical goals rounded out the list. ${ }^{2}$

In conclusion, secularism is a major player in our world (and church)today. SDAs may not like it, but they must not ignore its impact on packaging the gospel.

${ }^{1}$ Ibid., $62-65$.

${ }^{2}$ Paulien, Meeting the Secular Mind, 186. 


\section{CHAPTER THREE}

AN OVERVIEW OF BIBLICAL AND SDA LITERATURE

ON REACHING THE SECULAR MIND

\section{Biblical Literature}

\section{God Wants Us to Reach All People-Groups}

The apostle James speaks of Simon (Peter) saying that God "concerned Himself about taking from among the Gentiles a people for his name" (Acts 15:14 NASB) . ${ }^{1}$ Then James quotes Amos 9:11-12 from the LXX:

"With this the words of the Prophets agree, just as it is written, After these things I will return, And I will rebuild the tabernacle of David which has fallen, And I will rebuild its ruins, And I will restore it, So that the rest of mankind may seek the Lord, And all the Gentiles who are called by my name,' Says the Lord, who makes these things known from long ago" (Acts 15:15-18).

So God is interested in the rest of humankind, He has Gentiles who are called by His Name. To the old Testament child of God there were only two groups in the world: the children of Abraham and everybody else.

God wants a house of prayer for all peoples (Isa 56:7).

${ }^{1}$ All biblical quotations are from the NASB unless otherwise stated. 
The gospel must "be preached in the whole world as a testimony to all the nations, and then the end will come" (Matt 24:14). God is not coming back until we have reached all people groups, including the secular-minded people. The gospel commission commands God's followers to "make disciples of all the nations" (Matt 28:19); we are to preach the gospel to "all creation" (Mark 16:15).

When Jesus left His disciples to go back to heaven, His parting words spoke of being His witnesses "even to the remotest part of the earth" (Acts 1:8). That includes the inner city, the castles of the rich, and the unchurched. The New Testament church members had "favor with all the people" (Acts 2:47).

It is true that Christ at first told His disciples not to go looking for Gentiles or Samaritans. Initially, they confined their activities to the "lost sheep of the house of Israel" (Matt 10:6). God's Word was to go to the Jews first. However, Christ said that He had other sheep: "I have other sheep, which are not of this fold; I must bring them also, and they will hear My voice; and they will become one flock with one shepherd" (John 10:16).

After the Jews started contradicting themselves and blaspheming God at Pisidian Antioch, Paul and Barnabas told them "seeing ye put it from you, and judge yourselves unworthy of everlasting life, 10, we turn to the Gentiles" 
(Acts 13:46 KJV).

Paul was hand-picked by God to bear His Name "before the Gentiles" (Acts 9:15), "unto the ends of the earth" (Acts 13:47).

God sent Paul to the Gentiles,

"to open their eyes so that they may turn from darkness to light and from the dominion of Satan to God, that they may receive forgiveness of sins and an inheritance among those who have been sanctified by faith in Me" (Acts 26:17-18).

The Gentiles "will also listen" (Acts 28:28). Paul

later wrote to the church at Ephesus (composed of both Jews and Gentiles) that the Gentiles were "fellow heirs and fellow members of the body, and fellow partakers of the promise in Christ Jesus through the gospel" (Eph 3:6). Obviously, there were unchurched worldly Gentiles who responded to the gospel call!

\section{Preach Christ}

There are many approaches being tried today to reach the secular mind. Highly creative technology, worship service design and music, brilliant preaching, magnetic personalities, and small groups are just a few examples. These are all useful, but not primary.

Christ summed up successful evangelism in two words: "Follow Me." These simple two words must not detract from

${ }^{1}$ Matt $4: 19$. 
their "atomic power." Christ is the sole Savior from sin." Christ is to be lifted up because He is the True drawing power. $^{2}$ Philip went to Samaria, proclaiming Christ. ${ }^{3}$ Paul put it this way:

Where is the wise man? Where is the scribe? Where is the debater of this age? Has not God made foolish the wisdom of the world? For since in the wisdom of God the world through its wisdom did not come to know God, God was well-pleased through the foolishness of the message preached to save those who believe. For indeed Jews ask for signs and Greeks search for wisdom; but we preach Christ crucified, to Jews a stumbling block and to Gentiles foolishness, but to those who are the called, both Jews and Greeks, Christ the power of God and the wisdom of God. Because the foolishness of God is wiser than men, and the weakness of God is stronger than men. ( 1 Cor $1: 20-25$ )

Paul was an extraordinary orator, yet he learned at Mars Hill ${ }^{4}$ that Christ must be first and foremost. We must not rely on human skill.

The New Testament church members, every day, in the temple, in the homes, "kept right on teaching and preaching Jesus as the Christ" (Acts 5:42). They were ambassadors for Christ. ${ }^{5}$

\footnotetext{
${ }^{1}$ Matt $1: 21$.

${ }^{2}$ John $12: 32$.

${ }^{3}$ Acts $8: 5$.

${ }^{4}$ Acts $17: 22 \mathrm{ff}$.

${ }^{5} 2 \operatorname{Cor} 5: 20$.
} 


\section{Address Practical Human Needs}

One of the great criticisms of secular-minded people is that the church ignores or sidelines practical living issues. The church is "other worldly" to the exclusion of living in this world, not feeling the need to make a positive impact in this world with the day-to-day issues that face humanity.

Jesus said that the separation of sheep and goats would be based on whether a person was giving practical help to others in need. We must feed the hungry, cloth the naked, visit the sick and those in prison. ${ }^{1}$

Jesus fed people by the thousands. He did not ignore the current needs of His audience. He helped people with their addictions. ${ }^{2}$ Attending to their immediate needs caused them to be more receptive to Him. This ministry of helping people with their physical needs was later delegated to "deacons" so that the apostles could primarily "devote themselves to prayer and the ministry of the word" (Acts 6:1-4) God cares for the total person, the needs of this life and the future kingdom of glory.

${ }^{1}$ Matt 25:31-40. Nutrition schools, Community Service societies with clothing distribution, working with the ageing society, and Prison Ministry are just a few ideas envisioned in this scripture.

"Isa 61:1-3. "Liberty" from substance abuse, and sexual and emotional abuse is implied here also because these addictions hold us captive. See John 8:34. 
Pure and undefiled religion includes visiting the orphans and widows. It includes helping them relieve their distress. ${ }^{1}$ These good deeds are profitable and helpful. ${ }^{2}$

The disciples were empowered to heal every kind of disease and sickness, emotional and physical. ${ }^{3}$ They did not just go around preaching an abstract other-worldly gospel that ignored the present. They kept at it "every day," a seven-day-a-week church program. ${ }^{4}$ And daily God added to their numbers. Members were not just indoctrinated and added to the church roster during the Sabbath church service. ${ }^{5}$ There "was not a needy person among" the New Testament church members. ${ }^{6}$ That is practical Christianity!

\section{Selected Parables of Jesus}

Jesus' usual method of teaching/preaching was the parable. ${ }^{7}$ our Creator knew that people liked stories to which they could relate. Parables helped people to visualize abstract concepts; they "pulled people into" the

${ }^{1}$ Titus $1: 27$.

${ }^{2}$ Titus $2: 7,14 ; 3: 8$. Heb $10: 24$ talks about stimulating one another to love and good deeds (practical Christianity).

${ }^{3}$ Matt $10: 1$.

${ }^{4}$ Acts $2: 46 ; 5: 42$.

${ }^{5}$ Acts $2: 47$.

${ }^{6}$ Acts $4: 34$.

${ }^{7}$ Matt $13: 34$. 
insight being discussed. Christ's parables portrayed everyday life in graphic language. Secular-minded people are focused on this life.

The lost sheep, coin, son

Christ gave three examples of lostness in Luke 15. God cares about lost people! God searches for that one "lost" person outside of church membership and/or outside of a personal relationship with Him. God is searching for that person who loves riches, the one who has no faith in Him, ignores Him, the person who is addicted to what the world has to offer. The "Lost Sheep" knows they are lost but they are unable to get back to the fold. The "Lost Coin" is totally lost, not knowing it is lost or how to get back. The "Lost Son" knows he is lost, he knows how to get back, and the dad is there waiting for him day by day. The point Jesus is trying to make is that He cares for all people, no matter what their hang-up. He cares for secular-minded people who think that they do not need God.

The sower

The parable of the sower is really a parable about soils, about receptivity. ${ }^{1}$ Some people-groups are more receptive, showing more spiritual growth when the gospel

${ }^{1}$ Matt 13. 
seed is sown in their hearts. ${ }^{1}$

Fishing for Jesus

Christ compared spreading the gospel with fishing. ${ }^{2} \mathrm{~A}$ hook suggests spreading the gospel one-on-one. The net represents gathering people in groups, such as through evangelistic meetings. This "hook" comparison is most helpful in reaching secular people. ${ }^{3}$ Various ideas would include:

1. Which hook to use

2. Where to throw the hook

3. The best way to throw the hook

4. What kind of fish are you looking for

5. How to care for the fish once caught

6. What equipment is needed

7. What type of water do the fish live in

8. What is the geographical area (type of society)

9. Are you fishing at day or night

10. Is the tide in or out

11. What are the customs of the fish.

${ }^{1}$ Matt $13: 8$.

${ }^{2}$ Matt $4: 19$.

${ }^{3} \mathrm{Dr}$. Ricardo Norton, class notes for CHMN664, Training and Motivation of Laity in Ministry, Takoma Park, Maryland, March 1996. 
Cloth and wineskins

The parable of cloth and wineskins will bring this section to a close:

And He was also telling them a parable: "No one tears a piece of cloth from a new garment and puts it on an old garment; otherwise he will both tear the new, and the piece from the new will not match the old. "And no one puts new wine into old wineskins; otherwise the new wine will burst the skins and it will be spilled out, and the skins will be ruined. "But new wine must be put into fresh wineskins. "And no one, after drinking old wine wishes for new; for he says, 'The old is good enough'." (Luke 5:36-5:39)

It is easy for us to grow accustomed to old ways of doing things, to tradition. Old shoes, broken in to fit our feet, feel the best. This parable speaks of deep-seated prejudice, of not wanting to look at things another way, of thinking our "old ways" are the best, of doing things the same way they have been done for centuries. We cannot stick with tradition, as such, and reach the secular mind.

Secular-minded people want change, they want practical religion, they want a religion that keeps up with the times, and they want a religion that meets specific needs.

Just saying "it's inspired" is not enough for the secular mind. Any number of inspired sayings from various holy people are all equally good, or bad.

We tend to look at things through our own personal lenses, based on our environment, our traditions. We need to be open to brand-new ways of looking at things. 


\section{Selected Interviews of Jesus ${ }^{1}$}

Nicodemus

It is crucial in reaching the secular mind to treat each individual as a unique opportunity. We can see this in Christ's interview with Nicodemus. ${ }^{2}$ Christ's approach with Nicodemus included the following:

1. Christ adapted His methods to each person/ situation.

2. He took into account Nicodemus' social background. He spoke to him directly and profoundly.

3. He looked for the reason behind the reason.

4. He evaded discussion and argumentation.

5. He presented the necessity of the cross.

6. He presented the necessity of the Holy Spirit.

7. He presented the necessity of baptism.

8. He alluded to conversion, to change.

The Samaritan woman

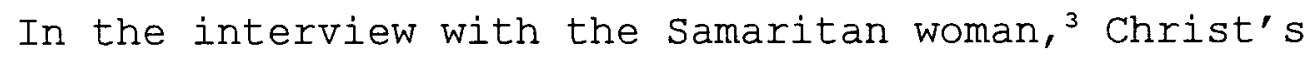
approach including the following points:

1. Christ awakened interest through secular conversation. He used His need for water to reach her. 2. He used ingenuity, initially asking for water,

${ }^{1}$ Norton, class notes.

${ }^{2}$ John $3: 1-21$.

3ohn $4: 4-42$. 
ending up offering better water.

3. He spoke with authority, stating that she would never thirst again.

4. He pointed to a higher life, heavenly things.

5. He used euphemism, saying hard things in a palatable way.

6. He chose the questions he wanted to answer and ignored the others.

7. He avoided confrontational questions.

8. He struck for the open nerve that causes a person to expose their need(s).

9. He told the truth, even when it hurt.

10. He agreed with the person as much as possible.

11. He did not allow the conversation to get off the subject.

The rich young ruler

The interview with the "Rich Young Ruler"1 is particularly informative in reaching the secular mind. While being a devout Jew, he still focused on this world's material possessions and status, the "here and now." This is also characteristic of secular-minded people. He had all that a worldly oriented person could want, yet he was not happy. Christ's approach in this interview included the following points:

${ }^{1}$ Luke 18:18-30. 
1. Love to God and humanity are foundational to personal happiness.

2. Obeying the commandments without love does not bring happiness.

3. Christ must be accepted as the Messiah, not merely as another good speaker.

4. Wealth can easily become a trusted god, which does not bring happiness.

5. True happiness comes from being willing to sacrifice for the benefit of others.

6. We must abandon our idols, i.e. wealth, in order to follow Christ with integrity.

7. The ruler's refusal to follow Jesus is proof that the best methods are not always successful.

\section{Selected Passages on Methodology}

Christ sent the disciples out in pairs; ${ }^{1}$ He required an evaluation period when they came back. ${ }^{2}$ They needed to adapt their approach to the churched and unchurched, to the religious and non-religious, to the spiritual in contradistinction to the worldly person. Paul illustrated this:

${ }^{1}$ Mark $6: 7$.

${ }^{2}$ Mark 6:30. 
For though I am free from all men, I have made myself a slave to all, so that I may win more. To the Jews I became as a Jew, so that I might win Jews; to those who are under the Law, as under the Law though not being myself under the Law, so that I might win those who are under the Law; to those who are without law, as without law, though not being without the law of God but under the law of Christ, so that I might win those who are without law. To the weak I became weak, that I might win the weak; I have become all things to all men, so that I may by all means save some. I do all things for the sake of the gospel, so that I may become a fellow partaker of it. (1 Cor 9:2023)

The disciples held home meetings often, gave people only as much information as they were able to bear, ${ }^{1}$ and realized that new church planting was needed at times instead of trying to convince the "old timers" to change their traditional beliefs and practices. ${ }^{2}$

2 They went where the fish were biting, where receptivity was better only after their gospel presentation was not received. ${ }^{3}$ They worked with the thirsty and those who needed extra time.

Christ's followers made the most of every opportunity

1John 16:12. See also Acts 15 where the New Testament church discussed how to treat new converts.

${ }^{2}$ Acts 22:17-21. Paul had to leave Jerusalem and start a new work among the Gentiles.

${ }^{3}$ Matt $10: 14$. 
with outsiders; ${ }^{1}$ they were sensitive to local culture. ${ }^{2}$ They talked in the heart language of the receptors. ${ }^{3}$ They had a relational ministry and invited people over to their homes for get-togethers. ${ }^{4}$ They went over to worldly people's homes for food and fellowship, realizing that the spiritually sick needed their friendship. ${ }^{5}$ They shared Jesus with their relatives. ${ }^{6}$

They realized the utmost importance of being "in the world," of taking an active part in their communities. They made a practical difference in their world; they made this world a better place. They were not hermits, "too good" to touch the secular world. They touched it mightily with the good news of Jesus. ${ }^{7}$

In balance, the effective New Testament church member

${ }^{1} \mathrm{Col} 4: 5$.

${ }^{2}$ Luke $10: 8$.

${ }^{3} 1$ Cor. $14: 19$. Paul said it was better to speak a few words in a language that the receptor understood, than thousands of words in a language that they did not understand. He saw the importance of "talking their language" in presenting the gospel.

${ }^{4}$ John $1: 37-39$.

${ }^{5}$ Matt $9: 10-13$.

${ }^{6}$ John $1: 41$.

${ }^{7}$ John $17: 14-16$. 
guarded against being stained by the world; ${ }^{1}$ they would not conform to the world, ${ }^{2}$ and would not participate in worldly deeds of darkness. ${ }^{3}$ They would choose not to marry unbelievers just to hopefully win them to Christ. ${ }^{4}$

Although they experienced deeply their new freedom in Christ, they did not turn it into "an opportunity for the flesh" (Gal 5:13). Lust was still lust, pride was still pride, worldliness was not an option. ${ }^{5}$ They were open minded, willing to try new methods to reach others with the gospel, yet they were faithful to that which was good. ${ }^{6}$ They were not "carried away by varied and strange teachings" (Heb 13:9).

They understood that while cultures change, while various people-groups were best reached with methods attuned to their heart-language, Jesus was always the same.'

We will now turn to an overview of Adventist authors and their suggestions for effective evangelism to the
${ }^{1}$ Jas $1: 27$.
${ }^{2}$ Rom $12: 2$.
${ }^{3} \mathrm{Eph} 5: 11$.
${ }^{4} 2$ Cor $6: 14-17$.
${ }^{5} 1$ John $2: 16$
${ }^{6} 1$ Thess 5:21.
${ }^{7} \mathrm{Heb} 13: 8$. 
secular mind.

\section{SDA Literature}

\section{Ellen White}

Ellen White is considered an inspired author by the Seventh-day Adventist denomination. As such, I will spend more time overviewing her writings.

Marketing the gospel

If you would approach the people acceptably, humble your hearts before God, and learn His ways. We shall gain much instruction for our work from a study of Christ's methods of labor and His manner of meeting the people. In the gospel story we have the record of how He worked for all classes, and of how as He labored in cities and towns, thousands were drawn to His side to hear His teaching. ${ }^{1}$

"We all must learn His methods of working"; ${ }^{2}$ His "method alone will give true success in reaching the people." 3

Christ did not merely announce His blessings; He presented them "in the most alluring terms," "the most attractive way, to excite a desire to possess them."4 In

${ }^{1}$ Ellen G. White, Evangelism (Washington, DC: Review and Herald, 1946), 53.

${ }^{2}$ Ibid., 109.

${ }^{3}$ Ellen G. White, The Ministry of Healing (Mountain View, CA: Pacific Press, 1905), 143.

${ }^{4}$ Ellen G. White, The Desire of Ages (Mountain View, CA: Pacific Press, 1898), 826. 
reaching the secular mind, we must understand how these people think, what interests them in order to attract them. We must speak to humanity in the "language of humanity."1 It is like baiting with the right hook, depending on which fish you are trying to catch. ${ }^{2}$

The "tameness," the "monotony" in our service for God "repels many."3

We must teach our members the best way to approach "individuals and families."4 Christ varied His messages to "suit His audience."5 The way we present truth has a lot to do with whether it will be accepted or rejected. ${ }^{6} \mathrm{He}$ "surprised them with illustrations that won their attention," and were "taken from the things of daily life"; He appealed to their "imagination."7 Some "in the higher walks of life will grasp it as it is presented in figures

${ }^{1}$ Ibid., 34 .

${ }^{2}$ White, Evangelism, 556.

${ }^{3}$ Ibid. , 170 .

${ }^{4}$ Ellen G. White, Christian Service (Hagerstown, MD: Review and Herald, 1925), 227. See the entire chapter "Methods."

${ }^{5}$ White, The Desire of Ages, 254 .

${ }^{6}$ White, Evangelism, 168 .

${ }^{7}$ White, The Desire of Ages, 254. 
and parables."1

Christ's servants should "accommodate themselves to the varied conditions of the people. . . Labor will have to be varied to meet the people where they are."2

Christ centered His ministry "along the great thoroughfares of travel." Those seeking to touch lives for Christ need to go to "centers of tourist traffic."

Workers would be "far more successful" if they followed His plan in working two by two, encouraging, counseling, and praying with one another. One's strengths could supplement the other's weaknesses. ${ }^{4}$

We must "leave no means untried,"5 be "many-sided men," "not be one-idea men," and our "truth must vary with the class of people" we are working with. ${ }^{6}$ The class of people we are trying to reach will determine what methods we use.?

${ }^{1}$ White, Evangelism, 557. See also idem, The Desire of Ages, 314, where we see Jesus using an illustration to "drive home" His lessons.

${ }^{2}$ Ellen G. White, Testimonies for the Church (Mountain View, CA: Pacific Press, 1948), 2:673.

${ }^{3}$ White, Christian Service, 126-127.

${ }^{4}$ White, The Desire of Ages, 350 .

${ }^{5}$ White, Evangelism, 63.

${ }^{6}$ Ibid., 106.

${ }^{7}$ Ibid. 
Change must be expected. New methods "must be introduced." The "lifeless way in which it [reaching people for Jesus] has been carried forward in the past" must cease. ${ }^{1}$ We must "arrest the attention," and "do something out of the common course of things." ${ }^{2}$ No fixed rules apply, all methods can be improved. We must be progressive. ${ }^{3}$

It is important to use a plain, direct manner, not bringing too many things to the receptor at once. Use simple language. ${ }^{4}$

When entering a new area, do not say right off, "Hello, I'm a Seventh-day Adventist." This will erect a formidable barrier. Speak to others at first about things that you agree on, dwelling on practical religion.5 Do not "press unwisely" the peculiar points of our faith. ${ }^{6}$

Our consistent daily example will help greatly in bringing people to Christ in this unbelieving secular world. Noteworthy, learned people are reached better by the

${ }^{1}$ Ibid. , 70 .

${ }^{2}$ Ibid. , 122 .

${ }^{3}$ Ibid. , 105.

${ }^{4}$ Ibid. , 55 .

${ }^{5}$ Ellen G. White, Gospel Workers (Washington, DC: Review and Herald, 1915), 119 .

${ }^{6}$ White, Testimonies for the Church, 7:109. 
"simplicity of a godly life than by all the sharp arguments that may be poured upon them."1 In fact, sharp or cutting remarks, "thrusting upon the people the very strongest positions . . . must be put aside." ${ }^{2}$ Meeting opposition with argument will only multiply it. ${ }^{3}$ Do not invite persecution; do not denounce your opponents. ${ }^{4}$

The people of God are His representatives upon the earth, and $\mathrm{He}$ intends that they shall be lights in the moral darkness of this world. Scattered all over the country, in the towns, cities, and villages, they are God's witnesses, the channels through which He will communicate to an unbelieving world the knowledge of His will and the wonders of His grace. It is His plan that all who are partakers of the great salvation shall be missionaries for Him. The piety of the Christian constitutes the standard by which worldlings judge the gospel. Trials patiently borne, blessings gratefully received, meekness, kindness, mercy, and love, habitually exhibited, are the lights that shine forth in the character before the world, revealing the contrast with the darkness that comes of the selfishness of the natural heart. ${ }^{5}$

In talking with the Samaritan woman, Christ spoke very candidly with her, telling her that He was the Messiah. ${ }^{6} \mathrm{He}$ could not have been this plain-spoken with the self-

${ }^{1}$ White, Evangelism, 557.

İIid., 299.

${ }^{3}$ Ibid., 302 .

${ }^{4}$ Ibid., 304-305.

${ }^{5}$ Ellen G. White, Patriarchs and Prophets (Washington, DC: Review and Herald, 1890), 134.

${ }^{6}$ John $4: 26$. 
righteous Jew. He was much more reserved when speaking with them. In fact, he told His disciples to keep His Messiahship a secret. ${ }^{1}$ Christ was looking for the key to her heart." And angels will help us to find "the key to the heart of the most incorrigible and unruly. ${ }^{3}$

Meeting people's needs

"The evidence of His divinity was seen in its adaptation to the needs of suffering humanity. His glory was shown in His condescension to our low estate." ${ }^{4}$ We are to go to our neighbors, come close to them, and "watch for opportunities to do them good." ${ }^{5}$ Logic and argument may not convince people of our message, but "the love of Christ, revealed in personal ministry, may soften the stony heart, so that the seed of truth may take root." ${ }^{6}$

People's "physical wants must first be relieved."7 Christ "went from house to house, healing the sick,

${ }^{1}$ Matt $16: 20$.

${ }^{2}$ White, The Desire of Ages, 183.

${ }^{3}$ Ellen G. White, Counsels on Sabbath School Work (Washington, DC: Review and Herald, 1938), 175.

${ }^{4}$ White, The Desire of Ages, 217.

${ }^{5}$ White, Christian Service, 116.

${ }^{6}$ Ibid., 117.

'Ibid., 114 . 
comforting the mourners, soothing the afflicted, speaking peace to the disconsolate. . . He met every form of human woe and affliction."1 He showed first that He cared about their personal daily needs, and that made people open to what He had to say.

We should do as Christ did. . . Wherever He was, - . He spoke to men of the things pertaining to the higher life. The . . events of daily life were bound up by Him with the words of truth. The hearts of His hearers were drawn to Him; for He had healed their sick, had comforted their sorrowing ones, and had taken their children in His arms and blessed them. When He opened His lips to speak, their attention was riveted upon Him, and every word was to some soul a savor of life unto life. ${ }^{2}$

Christ's method alone will give true success in reaching the people. The saviour mingled with men as one who desired their good. He showed His sympathy for them, ministered to their needs, and won their confidence. Then He bade them, "Follow Me." 3

Jesus "linked Himself with the interests of humanity." In order to reach all classes, He met them where they were. He did not ask, "What is your denomination?" He instead just "helped all who needed help."4

Paul at first tried to impress his audience with his skills of oratory. But he set that aside. He learned that

${ }^{1}$ Ibid.

${ }^{2}$ Ibid. , 119.

${ }^{3}$ White, The Ministry of Healing, 143.

${ }^{4}$ White, Christian Service, 122-123. 
touching the daily experience of those he was trying to reach, helping them with their "battles of life," their "immediate needs," and their "present trials" opened the door to share Christ with them. ${ }^{1}$

We must work with the sick and care for their needs, for "through this means you can reach their hearts." 2 We need to "awake to the necessities of the times [needs of the people] in which [we] are living." ${ }^{3}$

Jesus saw in every soul one to whom must be given the call to His kingdom. He reached the hearts of the people by going among them as one who desired their good. He sought them in the public streets, in private houses, on the boats, in the synagogue, by the shores of the lake, and at the marriage feast. He met them at their daily vocations, and manifested an interest in their secular affairs. . . . His strong personal sympathy helped to win hearts. ${ }^{4}$

We need to "reach the people where they are." Jesus gained access to hearts through their "most familiar associations"; He "made them feel the completeness of His identification with their interests and happiness."6

${ }^{1}$ Ellen $G$. White, The Acts of the Apostles (Mountain View, CA: Pacific Press, 1911), 251-252.

${ }^{2}$ White, Christian Service, 129.

${ }^{3}$ White, Evangelism, 70 .

${ }^{4}$ White, The Desire of Ages, 151.

${ }^{5}$ White, Evangelism, 122.

${ }^{6}$ White, The Ministry of Healing, 23. 
The Israelites failed in part to bring blessings to the world because they were "untouched by the needs of those around them."1

Reaching out to the worldly person

God wants us to work diligently "in places where people know nothing of the Bible truth."2 The life of the church "depends on the interest which its members manifest in those outside the fold." 3 To neglect this work invites "spiritual feebleness and decay."4 "Many are on the verge of the kingdom, waiting only to be gathered in." 5

Speak of Christ

"Christ is to be our text" to "tell the story of the cross." We need to watch for opportunities to speak of

${ }^{1}$ Ellen G. White, Prophets and Kings (Mountain View, CA: Pacific Press, 1917), 371.

${ }^{2}$ White, Christian Service, 114.

${ }^{3}$ Ellen G. White, This Day with God (Washington, DC: Review and Herald, 1979), 242.

${ }^{4}$ White, The Desire of Ages, 825.

${ }^{5}$ White, The Acts of the Apostles, 109. This statement is given in reference to the Ethiopian eunuch, a secular, worldly person.

${ }^{6}$ White, Christian Service, 113. 
Him. "Talk it, pray it, sing it, and it will break and win hearts."2 "The message borne in the love of Christ, with the worth of souls constantly before us, would win even from worldlings the decision: 'They are like Jesus'."3

Do not repeat falsehoods

When people you are working with come up with errors, "do not repeat their statements, but hold to your assertions of the living truth."

Work one-on-one

"The work of Christ was largely made up of personal interviews." 5 His grace, to a great degree, must be brought to the world by "personal labor. This was Christ's method."6 It is "one of the most effective ways" of sharing Christ. ${ }^{7}$

${ }^{1}$ Ibid. , 119.

${ }^{2}$ Ibid., 130 .

${ }^{3}$ White, Testimonies for the Church, 3:160. See the entire chapter "Intimate Friendship With Worldiings."

${ }^{4}$ White, Evangelism, 302 .

${ }^{5}$ White, Christian Service, 116.

${ }^{6}$ Ibid., 117.

${ }^{7}$ Ibid., 118. 
Sermons will not do it. By visiting the people, talking, praying, sympathizing with them, you will win hearts. This is the highest missionary work that you can do. ${ }^{1}$

Many who are now left to darkness and ruin could have been helped, had their brethren--common men and women--come to them with the love of christ glowing in their hearts, and put forth personal efforts for them. Many are waiting to be thus personally addressed. Humble, earnest conversation with such persons, and prayer for them, heart being brought close to heart, would in most cases be wholly successful. But instead of this, those who profess to be following their Saviour rest content with expressing a desire that some brother or minister may come and help them. Thus they neglect the very work that God has left for them to do. ${ }^{2}$

Public worship services

The Sabbath meetings, the morning and evening service in the home and in the chapel, unless wisely planned and vitalized by the spirit of God, may become the most formal, unpleasant, unattractive, and to the youth the most burdensome, of all the school exercises. The social meetings and all other religious exercises should be so planned and managed that they will be not only profitable, but so pleasant as to be positively attractive. ${ }^{3}$

The prevailing monotony of the religious round of service in our churches needs to be disturbed. . . . The Holy Spirit's power will move upon hearts when this dead, lifeless monotony is broken up, and many will begin to work in earnest who never before thought of

${ }^{1}$ Ibid., 118.

${ }^{2}$ Ellen G. White, "Christ's Commission," Second Advent Review and Sabbath Herald, 10 June, 1880, par. 5, The Complete Published Writings of Ellen G. White [CD-ROM] (Silver Spring, MD: Ellen G. White Estate, 1991).

${ }^{3}$ White, Testimonies for the Church, 6:174-175. 
being anything but idle spectators. ${ }^{1}$

There is too much formality in our religious services. . . Where the church is walking in the light, there will ever be cheerful, hearty responses and words of joyful praise. ${ }^{2}$

In balance

Although there are no fixed rules, the work must be progressive, methods must be improved, and "under the guidance of the Holy spirit, unity must and will be preserved." ${ }^{3}$

In the effort to be sympathetic and kind, still "the popular sins and indulgences of our day should be condemned and practical godliness enforced."

We need to monitor how much time we spend with those who seem separated from Christ:

God's servants are not to exhaust their time and strength in work for those whose whole lifetime has been devoted to the service of Satan till the entire being is corrupted. As the outcasts come, and they will come, as they came to Christ, we are to forbid them

${ }^{1}$ Ellen G. White, Testimonies to Ministers and Gospel Workers (Mountain View, CA: Pacific Press, 1923), 204.

${ }^{2}$ White, Testimonies for the Church, 5:318. See entire chapter "Praise Ye the Lord."

${ }^{3}$ White, Evangelism, 105. Concerning the church worship service, idem, "Behavior in the House of God," Testimonies, vol. 5, gives a balancing approach about the importance of reverence.

${ }^{4}$ White, Testimonies for the Church, $4: 396$. 
not. ${ }^{1}$

In our contact with "worldlings," our judgment may "become perverted." "Christian faith will never harmonize with worldly principles." ${ }^{3}$ We "are not to borrow the forms and customs of the world. . . Satan triumphs when he sees the leaven of the world working in the church, to the destruction of its purity and holiness." ${ }^{4}$

"Come out from among them, and be ye separate." 2 Corinthians $6: 17$. Shall we hear the voice of God and obey, or shall we make halfway work of the matter and try to serve God and mammon? There is earnest work before each one of us. Right thoughts, pure and holy purposes, do not come to us naturally. We shall have to strive for them. In all our institutions, our publishing houses and colleges and sanitariums, pure and holy principles must take root. If our institutions are what God designs they should be, those connected with them will not pattern after worldly institutions. They will stand as peculiar, governed and controlled by the Bible standard. They will not come into harmony with the principles of the world in order to gain patronage. No motives will have sufficient force to move them from the straight line of duty. Those who are under the control of the Spirit of God will not seek their own pleasure or amusement. If Christ presides in the hearts of the members of His church, they will answer to the call, "Come out from among them, and be ye separate." "Be not partakers of her sins."

${ }^{1}$ White, Evangelism, 554-554.

${ }^{2}$ White, Testimonies for the Church, 5:431.

${ }^{3}$ Ibid., 235.

${ }^{4}$ Ellen G. White, The Upward Look (Washington, DC: Review and Herald, 1982), 123. 
Revelation $18: 4.1$

"There is much in the nature and manner of Christ's work averse to every worldly principle." We must "trust ourselves wholly to His hands and confide in His love and wisdom." ${ }^{2}$

Christians will not choose the company of the unconverted unless attempting to win them to Jesus. God cannot keep a person safe from the enemy if they place themselves upon the enemy's ground; it is "an offense to God." ${ }^{3}$ We should not even permanently employ the unbeliever. ${ }^{4}$

While we are not to make ourselves "disgusting to unbelievers, $" 5$ we must not make the mistake the Israelites made :

Like Israel, Christians too often yield to the influence of the world and conform to its principles and customs, in order to secure the friendship of the ungodly; but in the end it will be found that these professed friends are the most dangerous of foes. The Bible plainly teaches that there can be no harmony

${ }^{1}$ Ellen G. White, Counsels on Health (Mountain View, CA: Pacific Press, 1923), 291.

${ }^{2}$ White, Testimonies for the Church, 5:219.

${ }^{3}$ Ellen G. White, our High Calling (Washington, DC: Review and Herald, 1961), 258.

${ }^{4}$ Ellen G. White, The Publishing Ministry (Hagerstown, MD: Review and Herald, 1983), 77.

${ }^{5}$ White, Testimonies for the Church, 1:413. 
between the people of God and the world. "Marvel not, my brethren, if the world hate you." 1 John $3: 13$. Our Saviour says, "Ye know that it hated Me before it hated you." John 15:18. Satan works through the ungodly, under cover of a pretended friendship, to allure God's people into sin, that he may separate them from Him; and when their defense is removed, then he will lead his agents to turn against them and seek to accomplish their destruction. ${ }^{1}$

The "worldling and the infidel admire consistency and have ever been powerfully convicted that God was of a truth with His people when their works correspond with their faith."

"The law of God will be satisfied with nothing short of perfection, of perfect and entire obedience to all its claims. To come halfway to its requirements, and not render perfect and thorough obedience, will avail nothing." ${ }^{3}$ We must make a decided, yet tactful and sympathetic stand for Jesus in our dealings with worldly people. "Unbelievers have a right to expect" more from those professing to keep the commandments of God and the faith of Jesus. ${ }^{4}$

\section{Jon Paulien}

The incarnation declares that God meets people where

$$
\begin{aligned}
& { }^{1} \text { White, Patriarchs and Prophets, } 559 . \\
& { }^{2} \text { White, Testimonies for the Church, } 1: 416 \text {. } \\
& { }^{3} \text { Ibid. }
\end{aligned}
$$

${ }^{4}$ Ellen G. White, Selected Messages, vol. 1 (Washington, DC: Review and Herald, 1958), 122. 
they are, talks their language, and expects followers to follow suit. The gospel proclamation must be contextualized in light of the prevailing culture. ${ }^{1}$

our culture is rapidly becoming virtually biblically illiterate. The church nowadays must speak primarily to "heathen."

Secular culture is prevalent today, even in the church. Television and other media are subtly influencing SDA church members, along with the rest of society, into secular ways of thinking. ${ }^{3}$ We need to study secularization because it may be the "modern-day counterpart of Hellenization which prepared the way for Christ's first advent." Many trends today suggest a developing world culture with English being the common language of business and administration. This is similar to the days of Christ: ${ }^{4}$

Providence had directed the movements of nations, and the tide of human impulse and influence, until the world was ripe for the coming of the Deliverer. The nations were united under one government. One language was widely spoken, and was everywhere recognized as the language of literature. ${ }^{5}$

${ }^{1}$ Paulien, Meeting the Secular Mind, 25.

${ }^{2}$ Ibid., 26.

${ }^{3}$ Ibid.

${ }^{4}$ Ibid. , 26.

${ }^{5}$ White, Desire of Ages, 32. 
Paulien suggests four actions that the world church should take:

1. Educate the entire church about its own secularization. Rather than helping evangelism, compromising these standards actually hinders it. It is the "secularized" churches that are in decline. When secular people get sick of what they have, they look for churches that make significant demands.

2. Move the church as a whole toward a more effective witness. Encourage different types of people to enter gospel work. Active involvement in social issues that do no compromise the faith of the church.

3. Teach the members of the church how to work for their neighbors and associates. Challenge college students to enter professions which influence the secular world (such as media, journalism, education, and the arts). The incredible diversify of the information age can best be met by lay persons in "secular" occupations. It is in the workplace that the best kinds of "secular evangelism" can occur.

4. Move out and bring in secular people. Have more contact with the real world. The church needs to form healthy, sacred subcultures (congregations) to which secular people can be directed when they sense their spiritual need. In their worship, teaching, and practice these local subcultures need to translated the gospel into language and action that address the secular situation.1

SDAs have historically had difficulty reaching anyone but religious people because we do not deal with issues that are relevant to secular people. The starting point is applying a specific gospel solution to a felt need. We screen out unwanted persuasion, yet when communication is directed toward a felt need, information that promises help

${ }^{1}$ Ibid. , 34-35. 
in meeting that need is understood to be useful. It gets a person's attention. ${ }^{1}$

Working with secular people is a lot of trial and error. A person must be able to identify easily with others, stimulate interest in the gospel in new and creative ways, communicate the biblical message faithfully, and express that message in language understandable to the listener. ${ }^{2}$

Simple listening goes a long way in reaching secular people. ${ }^{3}$ The information revolution utilizes self-help instead of institutional. Fellowship and interpersonal small-group ministry are much more effective than institutional ministry. ${ }^{4}$ Secular people are rarely reached in groups; one-on-one settings are best. A study by Gottfried Oosterwal of Lake Union Adventist churches (published in 1976) indicated that 85 to 90 percent of all baptisms came primarily as a result of personal contact with a relative, friend, or pastor. Public meetings, Adventist media, literature, and journals are considered, by those baptized, to play a significant role in less than one out of

${ }^{1}$ Ibid., $35-37$.

İId., 35.

IIbid., 39.

${ }^{4}$ Ibid., 33. 
four cases. ${ }^{1}$ Massive lay involvement is needed in this more personal model.

We use the Sabbath-Sunday issue as the center point of many traditional Adventist evangelistic series. This issue is totally irrelevant to the secularist. ${ }^{2}$

Secular people avoid the lecture approach, preferring to question, explore, and ask tough questions. They prefer to "negotiate their way into the faith."3

The typical Adventist worship service encourages a secular person not to come back. Practices such as "all visitors please stand (fear of commitment)," "please sign the guest book," "pass the offering plate (manipulation)," "let's sing a hymn (they do not know it)" all provide barriers. Would you like to sign a guest book at the neighborhood Buddhist temple? ${ }^{4}$

In our worship services, we need to use everyday language and avoid Adventist jargon. Whatever we do on Sabbath morning needs to be highly practical for Monday morning. We must deal with practical godliness. We must be concerned with excellence and for quality in everything that

${ }^{1}$ Paulien, present Truth in the Real World, 37.

${ }^{2}$ Ibid., 35 .

${ }^{3}$ Ibid. , 37.

${ }^{4}$ Ibid., $39-41$. 
we do as a church. Worship needs to be more visual and attention-grabbing than before. Secular people want to see authentic Christians. ${ }^{1}$

We tend to have our own in-house language. We need to learn how to speak to secular people, discarding code-words such as "the message," "the truth." They do not understand those terms.

In this media-saturated age, secular people are afraid of boredom. If the worship service does not appeal to young people, it will usually bore the secular visitor also. ${ }^{2}$

A local church or conference can do the following to make a bigger impact in the secular environment:

1. We need to educate our people in a number of areas. They must have a strong devotional life, along with reading chapter two in the book.

2. We must educate about the importance of Adventist lifestyle. Rather than helping evangelism, lowering standards hinders it. It is the "secularized" churches that are in decline. When secular people look for a church, they often pick the most demanding ones. Being conservative in the area of lifestyle is not a negative unless it is combined with a rigid and judgmental attitude.

3. Our people need education about the problem of horizons to help them understand that without a lot of listening and learning they will be ineffective in reaching secular people.

4. We must encourage a multiplicity of ministries. Secular people are as diverse as snowflakes. They are not normally reached in large groups. Every person has a special passion for something. They

\footnotetext{
${ }^{1}$ Ibid. , 183-201.

${ }^{2}$ Ibid. , 41.
} 
should serve in their area of passion. ${ }^{1}$

While many mainline traditional denominations continue to decline, evangelical churches that are not stuck in traditional ways of doing things are growing rapidly. ${ }^{2}$

\section{Monte Sahlin}

Sahlin is a researcher and consultant on the staff of the North American Division Chüch Ministries Department. He suggests that there have been three eras of Adventist evangelism. The first, "prophetic evangelism," was characterized by an emphasis on God's Word and a prophetic critique of the prevailing "apostate" churches. Preaching was the ticket to success; the great Adventist camp meetings were our pride and joy. ${ }^{3}$

When the early 1900 s rolled around, tent meetings had become relatively ineffective. The second era, "institutional evangelism," promised results through a Christ-centered system of Adventist doctrine. Evangelistic lessons and topic outlines became more important than the lecture itself. Church organization became more important

${ }^{1}$ Ibid. , $163-165$.

${ }^{2}$ Ibid. , 210 .

${ }^{3}$ Monte Sahlin, Sharing Our Eaith with Friends without Losing Either (Hagerstown, MD: Review \& Herald, 1990), 1415. 
than people.

During the 1980s Adventist pastors and congregations focused more on nurture. As the North American society became more secular, it became harder to get the growing unchurched society to respond to conventional evangelistic methods. Much the same situation exists today; there is a slow winding down of church growth, particularly among the Caucasian churches. ${ }^{1}$

The third era of Adventist evangelism is emerging, the era of "relational evangelism." There is much more emphasis on sharing one's personal faith journey than teaching a system of doctrines. Friendships are the primary tool of bringing people to Christ and church membership. The goal is to "meet the needs of people rather than to build up institutional programs." This relational strategy has been working for decades in the fast-growing Hispanic and Black churches. Family networks are the key to new converts. The emphasis is on meeting the economic, social, and physical needs of people along with their spiritual needs. ${ }^{2}$

North America may seem like a Christian continent, but really it is a neopagan culture. While 72 percent say they belong to a church or synagogue, two out of five people in

\footnotetext{
${ }^{1}$ Ibid. , 20-21.

${ }^{2}$ Ibid., 21 .
} 
North America have no real ties to any religion. Another third are nominal Christians; only about one in four is an active member. A full 69 percent are unchurched. ${ }^{1}$ The "Caring Church" strategy is "an attempt to reposition Adventist outreach, soulwinning, and nurture in terms of a relational approach." It is the first step in attempting to reach a more secular, urban, and media-driven culture. It consists of the following four points:

1. Moving witnessing to the workplace. During the past two decades the average workweek among Americans has increased from 40 to 49 hours, and the available free time has decreased from 27 to 17 hours per week. That means lay witnessing must move from neighborhood-based models to the arena of the workplace. Friendship evangelism skills must be developed and taught so that Adventists can effectively disciple the unchurched with whom they work.

2. Finding ways to successfully reach and disciple the affluent, educated, and younger adults. These are the groups that seem most resistant to Adventism and most likely to drop out of the church. The baby boom generation is returning to church.

3. Supporting and encouraging lay movements to reach people through small groups.

4. Planting new churches. This can do more to increase baptism among White, non-Hispanic North Americans than any other single activity. What is needed is not an emphasis on rural counties, but the planting of congregations designed to reach specific life-style clusters within large metropolitan areas. ${ }^{2}$

${ }^{1}$ Ibid., $37-38$.

${ }^{2}$ Ibid., $46-47$. 
Relational evangelism, working at the one-on-one level,

is a process that suggests three steps:

1. The Christian demonstrates caring and compassion through a genuine friendship that is unconditional-not conditioned by any behavior of the nonbeliever!

2. The Christian seeks to understand the needs of the unchurched friend as they are perceived by the unbelieving friend.

3. The Christian finds opportunities to share the alternative of faith in God as something that will meet the felt needs of the unchurched friend. Listening skills are the key to this approach, such as active questioning, checking out the feelings of another person, story listening. ${ }^{1}$

Training programs equipping members to reach the

secular mind must include at least three elements we missed in the past. Members must learn to relate to secular people in love and compassion. They need to recognize their nonChristian friends' perceived needs. And they must share their faith in a way that makes sense to a non-Christian. ${ }^{2}$ Church-growth consultants consistently find that congregations experiencing a drop in weekly attendance often have a worship service and other church programs that focus entirely around the interests of middle-aged or senior $\operatorname{adults} .^{3}$

$$
\begin{aligned}
& { }^{1} \text { Ibid., } 50-51 . \\
& { }^{2} \text { Ibid., } 55 . \\
& { }^{3} \text { Ibid., } 60 .
\end{aligned}
$$




\section{Ken Cox}

Cox is presently an evangelist working at the Adventist Media Center. He provides James Engel's chart in his book Contemporary Christian Communications ${ }^{1}$ that portrays a person's steps from knowing nothing about God to one who is a committed Christian. His decision-process chart is shown below (see table 3):

The secular minded individual is in categories $-8,-7$, or -6 . We need a strategy to reach that person. Results will usually be down the road. We must speak in terms of practical benefits, meeting their felt needs. Meeting felt needs will be an entering wedge to their heart. A survey can be used to discover their felt needs.

${ }^{1}$ James F. Engel, Contemporary Christian Communications, Its Theory and Practice (Nashville: Thomas Nelson, 1979). 
TABLE 3

THE PROCESS OF BECOMING A COMMITTED CHRISTIAN

\begin{tabular}{|l|l|}
\hline-8 & Awareness of Supreme Being \\
\hline-7 & Some Knowledge of Gospel \\
\hline-6 & Knowledge of Fundamentals of Gospel \\
\hline-5 & Grasp of Personal Implications of Gospel \\
\hline-4 & Positive Attitude Toward Act of Becoming a Christian \\
\hline-3 & Problem Recognition and Intention to Act \\
\hline-2 & Decision to Act \\
\hline-1 & Repentance and Faith in Christ \\
\hline
\end{tabular}

Source: Kenneth 0 . Cox, "Evangelistic Problems and Suggestions," in Meeting the Secular Mind: Some Adventist Perspectives, ed. Humberto M. Rasi and Fritz Guy (Berrien Springs: Andrews University Press, 1985), 80.

We tend to believe that people are ready to accept Jesus Christ, that they merely need to be shown how. However, most people in the Western world are not just waiting for someone to tell them how to accept Jesus. That idea usually comes later for them. ${ }^{1}$

Meeting secular people must be a "grass roots" effort, meeting them where they are: in their homes, on their streets, and in their jobs. Doing a demographic study in which we learn their nationality, age, income, etc., will help in effectively targeting a specific population. ${ }^{2}$

$$
\begin{aligned}
& { }^{1} \text { Sahlin, } 80 . \\
& { }^{2} \text { Ibid., } 82-83 .
\end{aligned}
$$




\section{Mark Finley}

Finley is currently speaker/director of the It is Written television ministry. He suggests contact ministry, crisis intervention, health ministry, and the direct spiritual approach as ways to approach the secular person.

In "contact ministry," we realize that not everyone is ready for a Bible study now. We must focus (70 percent of our time) on the approximate 30 percent of people who are receptive to a direct spiritual appeal, such as surveys, offers of Bible studies, evangelistic meetings, and seminars. The remaining populace can be reached only by programs that meet their felt needs, such as Breathe Free Plans, Stress Seminars, Nutrition Seminars, Family Life programs, etc. ${ }^{1}$

In crisis intervention, we touch people's lives at points of personal crisis, such as divorce, death of a loved one, loss of a job, or serious accident or illness. ${ }^{2}$

Health ministry meets peoples' felt needs in areas of their physical health. Each felt need is a point of receptivity. ${ }^{3}$

${ }^{1}$ Finley, "Target and Tactics," 103.

${ }^{2}$ Ibid., 104 .

'Ibid., 104 . 
In the direct spiritual approach, we just "come out and say it," talk of our love for Jesus, etc. ${ }^{1}$ He ends the chapter with the following quote:

Thousands of hearts can be reached in the most simple, humble way. The most intellectual, those who are looked upon and praised as the world's most gifted men and women, are often refreshed by the simple words that flow from the heart of one who loves God and who can speak of that love as naturally as the worldling speaks of the things which his mind contemplates and feeds upon. Often the words well prepared and studied have little influence. But the true, honest words of a son or daughter of God, spoken in natural simplicity, will open the door to hearts that have long been locked. ${ }^{2}$

\section{Daniel G. Matthews}

Matthews is former director of Faith for Today. He suggests that we do not have the challenge of trying to reach "secular" minds. We need to arrest the attention of human minds. ${ }^{3}$ If the church did not produce It Is Written or Breath of Life or Faith for Today, would we watch them instead of 60 Minutes or Good Morning, America? Christ's approach was to first earn the right to be heard by addressing felt needs. He answered questions people were.

${ }^{1}$ Ibid., 105.

${ }^{2}$ White, Testimonies for the Church, 6:115.

${ }^{3}$ Daniel G. Matthews, "Reaching the General Television Audience," in Meeting the Secular Mind: Some Adventist Perspectives, ed. Humberto M. Rasi and Fritz Guy (Berrien Springs: Andrews University Press, 1985), 158. 
asking in "terms and tones they understood." He always met people where they were. He sought "common ground." His approach was always, "How can I help you," never "What can you do for me?"1

"Westbrook Hospital," a Faith for Today TV serial, seems to interest those who are not looking for religion, who may in fact be trying to avoid it. It addresses various practical problems that people face. The story format is designed to arrest secular persons, arousing their interest subliminally. ${ }^{2}$

In trying to reach others, we must always ask, "Are we doing them any good?" It is never what the institutional church will get out of it. ${ }^{3}$

We particularly need to learn that effective marketing sells people the way they want to be sold, not the way we want to sell them. . . We must first satisfy wants before we endeavor to respond to needs. I appeal for serious marketing analysis."

In the editorial field, we are commissioned to "reach out to all people in all walks of life. Unfortunately, although our commission is inclusive, it is easy to become

${ }^{1}$ Ibid.

${ }^{2}$ Ibid.

${ }^{3}$ Ibid.

${ }^{4}$ Ibid. , 160. 
exclusive and restricted."1

The vast majority of people are not like us, they do not think like us, and they do not select priorities the way we do. They do not share our lifestyle, do not comprehend our terminologies, and have little in common with our heritage. As a result, much of what we do or say is irrelevant or foreign to them.

The church is no longer a major influence in society; the entertainment industry has replaced that influence. This is where the people are going. Our age is one of affluence and materialism; it caters to present gratification.

Virtually all our Adventist material goes to a small percentage of people who think about church. In fact, few Adventist-produced publications reach outside our denomination. Much of what we write could have been written for the general audience, if we are intelligent as to how to address that market. We need to allocate more funds to minister to people in our world who remain largely untouched by our message.

In reaching these people, we need to answer the questions people are asking, instead of offering solutions

${ }^{1}$ Dan Matthews, "Going Where the People Are: Isn't It Time We Embraced a Broader Ministry Focus?" Adventist Review, 19 August 1999, 8. 
for which the people do not even know the questions. This requires listening for the questions, addressing them, and avoiding subcultural terminologies. People must be sold what they will buy. "Scratch where it itches." We must go where the people are. ${ }^{1}$

\section{Dan Day}

Day spent several years as a corporate vice-president for marketing and as an Adventist pastor. He suggests that effective evangelism involves strategic marketing. Successful marketing brings about "organizational success through emphasizing greater responsiveness to the needs of the customer." 2

Marketing starts with the customer:

Essentially, marketing starts with the consumer of whatever products or services the organization is offering-asking pertinent questions about who the customer is, what the customer wants and needs, how the customer perceives the organization-and then goes on to use this information to guide how all systems are designed and all products are developed and offered. In short, instead of starting with the product, as companies typically did prior to the current emphasis on the marketing concept, marketing starts with the. customer. ${ }^{3}$

People today are going to churches that are marketing

${ }^{1}$ Ibid., 11.

${ }^{2}$ Dan Day, A Guide to Marketing Adventism (Boise: Pacific Press, 1990), 12.

${ }^{3}$ Ibid. 
themselves most effectively. Mainline churches, as well as SDA churches in North America, are losing their appeal.

For too long, we've been satisfied to blame the relatively slow advance of Adventism here in America on sociological factors beyond our control. "We live in a secular world," we've argued. "People don't want to hear the truth." To some degree this is true, of course. But could it be that they are also wearied, offended, or disenchanted by the way we've packaged our message?

We have been trying to sell Adventism when we should have been trying to market it. Selling begins with the product, and then attempts to convince the customer that they need it. Marketing, however, starts with the customer's needs, and then offers ways to satisfy those needs. Marketing makes selling superfluous. A marketer knows and understands the customer so well that the product fits and sells itself.

There are some in the church who would argue that all we can do is sell Adventism, since the character of our product is set. These are our beliefs, and we're not about to change them, no matter what. . . But such an attitude, when applied to our ministry to a lost world, is remarkably shortsighted. God's message to us is a need-satisfying message. To the degree that we don't couch it in those terms when we communicate to others, we're confusing people and doing the Lord a disservice.

The issue is not whether or not we change our beliefs or reorganize our church. It's whether or not we've understood our customers' needs well enough to

${ }^{1}$ Ibid., 15. 
show how what we have matches what they need. ${ }^{1}$

Paul adapted himself to the needs of others, and his message to the audience. To the Jew he became a Jew, to the Gentile a Gentile. ${ }^{2}$

People do not just buy products because somebody offers them; they buy to satisfy their felt needs. They buy solutions to their day-to-day problems. ${ }^{3}$

People have "windows" when they are more receptive to our message: when they are hurting, and when they are experiencing change or stress points. ${ }^{4}$

If we wish to be successful in reaching people, we need to understand where they are coming from. We tend to offer communities reflections of our perspectives and interests, not theirs. We ask them to become like us; then they will appreciate what we are all about. We have it backwards. ${ }^{5}$

We have tended to tell ourselves for years that as long as we proclaim the truth, Christ's sheep outside the fold will accept it. When they have not, instead of looking at

'Ibid., 16. This concept of "selling" or "marketing" the gospel is a controversial one. I will evaluate it in the last chapter.

${ }^{2}$ Ibid., 17

${ }^{3}$ Ibid., 59.

${ }^{4}$ Ibid., $168-169$.

${ }^{5}$ Ibid. , 173 . 
our attitudes and methods, we try to blame them. Taking the time to effectively market the truth is the answer. ${ }^{1}$

Marketing Adventism is everybody's business, not merely the pastor's. We need to catch the vision of a church filled with Christian marketers. And we market best right where we are, "in our own circle of friends, business associates, and fellow-travelers."2

\section{Bert B. Beach}

Beach was the director for Inter-Church Relations at the General Conference when he wrote the article "Adventism and Secularization." Beach gives ten suggestions to help approach secular people:

1. Provide basic instruction regarding Christianity, assuming that they know next to nothing. Make yourself interesting. Use more music, drama, and audience participation. Dialogue and participation are far more effective than monologue and exhortation.

2. Help people find meaning. People need help making sense of their lives.

3. Engage them in dialogue. Deal with their doubts and fears. Be vulnerable with them.

4. Provide opportunities for secular people to meet credible Christians. Legalistic Christians will not do; instead find members who will share their victories and struggles, those who care about others, not just about being "right" theologically.

5. Provide opportunities to overcome alienation. Many are alienated from nature, neighbors,

${ }^{1}$ Ibid., 174 .

${ }^{2}$ Ibid. 
friends, relatives. Sponsor retreats out in nature, small group meetings, support activities, and involvement in Christian social causes.

6. Provide opportunities to discover dignity and self-worth. Help them find their talents and spiritual gifts.

7. Provide hope. Christ's second coming is our greatest hope.

8. Provide support for addicted people. We must meet needs and offer freedom.

9. Provide and use social networks and contacts. Friendships are bridges. Adventists must join organizations with high standards and become friends with non-Adventists.

10. Provide and multiply units and services of the church. We need new groups, new "ports of entry," multiple ministries (not merely church worship service, Sabbath school, prayer meeting). Secular people "need to be needed," and they need to help others."

"Christianity needs to be relevant and be seen to be relevant. While we are not 'of the world,' we have a need to join the human race. We need to communicate the gospel persuasively and powerfully."2

\section{John W. Fowler}

Fowler was an Adventist evangelist and conference administrator when he wrote "Evangelism 2000: Proclaiming Christ in the $21^{\text {st }}$ Century." Mark Finley writes the foreword to the book. He suggests that there are "skeptics who say that evangelism is irrelevant" today. The church

${ }^{1}$ Bert B. Beach, "Adventism and Secularization," Ministry, April 1996, 24-25.

${ }^{2}$ Ibid., 25 . 
"must minimize its public evangelism thrust for more modern ways of reaching secular society." Finley suggests that biblical preaching is still Christ's method of reaching people. ${ }^{1}$

Fowler suggests that we need to adjust our evangelistic methods. During our formative period, 1863 and following, we made every sermon Christ-centered. We stressed personal witnessing, Bible studies, small group meetings. We focused on meeting people's physical needs.

However, "a blurred and self-defeating" negative evangelistic approach was later developed patterned after D. L. Moody and Billy Sunday. The approach offended Catholics, Protestants, and even our own members. ${ }^{2}$

Fowler quotes Roy Allan Anderson's article in Ministry which spoke of the Adventist evangelistic approach in the 1930 s as being "unfortunate." A program of subjects, presented in a startling manner, lasting for weeks or months was presented to perspective members. They drank it in, and many were baptized at the end of this "series." 3

However, in this cram session, the people were not able

${ }^{1}$ John W. Fowler, Evangelism 2000: Proclaiming Christ in the $21^{\text {st }}$ Century (Boise: Pacific Press, 1994), 5.

${ }^{2}$ Ibid., 9-12.

${ }^{3}$ Roy Allen Anderson, Editorial, Ministry, September 1932, 19, quoted in Fowler, Evangelism 2000, 13-14. 
to (nor should they have been expected to) assimilate all of these truths in the short time allotted. They had been startled, convicted, and they felt compelled to act. They were denounced as heretics if they did not accept all the truths presented and join the church. Fowler suggests that it was "a manipulative and divisive approach"; it "engendered a spirit of criticism and judgment among the members that ill-prepared them to care for the new members."1

Elder A. C. MCClure (former NAD President) has recognized this problem and has urged a genuine ministry of love that seeks to meet people's needs. He writes:

An argumentative approach reverses this (Christ's) method. We somehow conclude that if we could convince people of our doctrines they would want to join our fellowship. But a bit of reflective thinking about how society works would belie this notion. In fact, just the opposite is true. If we would bring people into our fellowship, then they would want to know our doctrine. ${ }^{2}$

We must accept people, bring them to fellowship with us, and become their friends. Then they will want to know our doctrines, be baptized, and become a part of the church family. Jesus focused on meeting the needs of the people.

${ }^{1}$ Ibid.

${ }^{2}$ A.C. MCClure, "Remembering the Mission," Adventist Review, March 5, 1992, 5, quoted in Fowler, Evangelism 2000, 15 . 
And the result? People willingly followed Him because He loved them, ministered to their needs, and they believed His teachings. ${ }^{1}$

We need to go among the people as Jesus did, desiring their good. Small group ministries are very effective in meeting people's fellowship needs. ${ }^{2}$

We must stop "converting" people to Adventism through rational, propositional truths alone. They must be truths emanating from Jesus. Our loving Jesus wants to share with us how to experience real joy and happiness. Happiness is not found primarily in mentally acceding to doctrinal truth. It is found in a healthy friendship with Jesus, which will naturally lead one to follow $\mathrm{Him}^{3}$

For a person to merely adopt a certain doctrinal viewpoint will accomplish little or nothing. Converts "cannot exist in society and maintain Christian values unless they are a part of a community that reinforces those values."4 Everybody needs a friend.

\section{J. David Newman}

${ }^{1}$ Eowler, Evangelism 2000, 15-16.

${ }^{2}$ Ibid., 19.

${ }^{3}$ Ibid. , 37.

${ }^{4}$ Howard A. Snyder, Liberating the Church (Downers Grove: Inter-Varsity Press, 1983), 115-116. 
Newman, former editor of Ministry Magazine, writes a critique on Paulien's book present Truth in the Real World. He ends his article with this pithy statement:

One point stands out above all others: if you are to reach secular people, you must spend time with them. Jesus said Christians must live as salt in the world. Unfortunately, because we are afraid that we might be contaminated by the world, we withdraw into fortresstype enclaves and mentalities. But if the salt does no penetrate and permeate the food, it will not be effective. While Romans 12:2 admonishes us not to be corrupted by the world, 1 Corinthians 9:22 says that we must become all things to all people in order that we might win some. Where do we find the balance? ${ }^{1}$

\section{Reinder Bruinsma}

Bruinsma was the secretary of the Trans-European

Division when he wrote the article "Contextualizing the Gospel-Option or Imperative?" He makes a case for contextualizing the gospel. Biblical revelation was always couched within a given historical context. Paul deliberately strove for contextualization (see 1 Cor 9:22). The incarnation itself proves that contextualization is essential to God's method. ${ }^{2}$

The Bible is clear that God's communication strategy is not merely pushing a set of propositions; it is to establish

${ }^{1} \mathrm{~J}$. David Newman, "Reaching the Secular Mind," Ministry, November 1993, 55.

${ }^{2}$ Reinder Bruinsma, "Contextualizing the Gospel--Option or Imperative?" Ministry, December 1997, 14. 
a relationship with human beings. He quotes Kraft:

To love is to seek the best for the recipient at whatever expense to the source. To love communicationally is to put oneself to whatever inconvenience to assure that the receptors understand. ${ }^{1}$

Bruinsma continues by stating:

Too often church leaders forget this principle and demand that the persons they seek to reach learn their language and their customs, appreciate their kind of music, come to their places of worship at their appointed times, and associate with their kind of people. ${ }^{2}$

Adventist pioneers said their message was present truth, a truth given for a particular time and relevant to people living in a particular historical context. ${ }^{3}$

\section{Bruce Campbell Moyer}

Moyer is currently professor of World Mission and Director of the Urban Study Center at Andrews University. Moyer's speciality is urban ministry. The number of nonChristian megacities has mushroomed from five in the year 1900 to 125 today. There is a steep decline of Christian populations in cities. Christians need to "alter their mission strategy from a rural-only priority to one that includes a clear focus on urban need." We need to reach

${ }^{1}$ Charles H. Kraft, Communication Theory for Christian Witness (Maryknoll, NY: Orbis Books, 1991), 14, quoted in Bruinsma, 15 .

${ }^{2}$ Bruinsma, 15 .

${ }^{3}$ Ibid. 
those migrating to the cities "becoming lost in the materialistic and secular complexity of urbanism."1

Moyer gives some timely questions that committed Christians need to address for effective urban ministry These questions are helpful in reaching the secular urban mind:

1. Where will the majority of people be found?

2. How might this majority of people best be addressed?

3. What sort of church is best able to adequately communicate the gospel to these people?

4. How can we best make faith possible for these people? ${ }^{2}$

Successful urban Adventist congregations will

"understand, accept, and have compassion for lost, unchurched people." They will obey the Great Commission to make faith possible for unreached people, adapting to the language, music, and style of the urban culture. One way of doing that is to become "Tentmakers," moving into an area and making friends. They should share what Jesus has done for them, not theologize. They should show how Jesus can improve one's quality of life. ${ }^{3}$

We now turn our attention to evangelical literature on how to reach the secular mind.

${ }^{1}$ Bruce Campbell Moyer, "Surrounded? Thank God! The Urban Paradox," Adventist Review, 5 June 1998, 13-14.

${ }^{2}$ Ibid.

${ }^{3}$ Ibid. , 15. 
CHAPTER FOUR

AN OVERVIEW OF SELECTED EVANGELICAL

LITERATURE ON REACHING THE SECULAR MIND

\section{George G. Hunter III}

Hunter is currently Dean of the E. Stanley Jones School of World Mission and Evangelism, at Asbury Theological Seminary in Wilmore, Kentucky. He suggests that the situation we face today is very similar to what the early apostolic Church faced. For the first three centuries, Christianity had to achieve four objectives:

1. Facing a population with no knowledge of the gospel, Christians had to inform people of the story of Jesus, the gospel etc.

2. Facing hostile populations and the persecution of the state, the Church had to "win friends and influence people" to a positive attitude toward the movement.

3. Facing an Empire with several entrenched religions, the Christians had to convince people of Christianity's truth, or at least its plausibility.

4. Since entry into the faith is by an act of the will, Christians had to invite people to adopt this faith and join the messianic community. ${ }^{1}$

After Christianity was established, it could skip the

${ }^{1}$ Hunter, How to Reach Secular People, 35. 
first three steps. However, with the fallout from secularism and the Church's defensive reaction, many people have been alienated from the Church and have withdrawn from the churches.

As a result, the church must begin farther back in the list of objectives cited above. For centuries the Church was harvesting grain in fields already plowed, seeded, and watered. But today, we need to first plow, seed, and water the fields before we can expect to gather a harvest. ${ }^{1}$

The secularization of the West has positioned the Church into a missionary role here at home. In fact, the West is the toughest mission field on earth. ${ }^{2}$

As we attempt to reach secular people, we need to be aware of three myths about secular people:

1. Secularization has erased all religious consciousness from people's minds. This is just not so. People are incurably "religious." Yet they pick and choose religious fragments at will, a belief here and a practice there.

2. Secularization has erased moral consciousness, so that secular people are simply "immoral." Again, this is just not so. But they receive their marching orders from parents, peers, or pop culture instead of the church or its

$$
\begin{aligned}
& { }^{1} \text { Ibid., } 36 . \\
& { }^{2} \text { Ibid., } 24 .
\end{aligned}
$$


Scriptures.

3. All secular people are philosophically sophisticated geniuses. False again. Most are naive, superficial, gullible people who may fall for anything. ${ }^{1}$

Hunter suggests seventeen themes and strategies for reaching secular people:

1. We need to provide ministries of instruction. If they are basically ignorant of Christianity, then they must be taught "What is Christianity?" Most teachers begin in the middle; we must begin with the story of Jesus, what He said, how He lived and died.

There are two rules of thumb: It is okay to be interesting; and people learn more effectively through participation than by passively receiving information.

We must assume that they know nothing. We must not ask them to read aloud in the group or to pray aloud or to answer questions about the Bible or Christianity. We must proceed slowly.

2. Invite people to dedicate their lives. Invite them to decisively and radically commit their lives to basic Christianity. We too often try to help people to continue something they have not yet begun.

3. Help secular people find meaning. If secular people today are less obsessed with life after death and

${ }^{1}$ Ibid. , 42-43. 
more obsessed with life this side of death, then the church that helps people make sense of their life and find meaning for their life will be scratching where many people itch. Churches that do not help people make sense of their lives and find meaning and purpose are neglecting their essential mission.

4. Engage secular people in dialoque. If conscious doubt, not conscious guilt, is now the number one factor in a secular population, what strategy is appropriate? Traditionally, the Church has relied on authoritative preaching to reach the unchurched masses, but most secular people experience such preaching as authoritarian preaching. It turns them off. The speakers who get a hearing today engage in animated conversation. TV has permanently altered the attention span of Americans, so get right to the point in your presentations.

5. Address secular people's doubts and questions.

6. Provide opportunities to meet credible Christians. Christianity is more caught than taught.

7. Provide opportunities for people to overcome alienation. Plan retreats in natural settings that enable people to get in touch with God's natural revelation. Provide small groups to bring healing to those alienated from their neighbors and relatives. Only in a vital Christian relationship will God become real to most people. 
The key to the problem of modern-day agnosticism is fellowship.

8. Engage in ministries of affirmation. Do not insult them, demean them, or come across as better than they are. Spend time with them, affirming them, and managing affirming experiences for them. Secular people need to know in advance that they will not be rejected, or insulted, or humiliated, or walk into a setup.

9. Help people discover their dignity and self-worth. If many secular people have low self-esteem, the doctrine of creation is good news. People must first discover their dignity and self-worth before they can become the kind of converts that the Christian movement needs.

10. Offer people hope in the Kingdom of God. If many secular people see history as out of control and fear the future, the Christian doctrine of the Kingdom of God (Second Coming, Providence) will bring security to this insecure generation.

11. Provide support groups for people with addictions. If many secular people are addicted and not in control of their Iives, then the "12-Step Movement" is here to stay. More people are now experiencing the empowering grace of God in the 12-step groups than in all of the more visible evangelism programs combined. Addiction is the dominant form that Evil has taken today in our culture. 
12. Identify and reach receptive people. Secular people experience receptive seasons in their lives when they are dissatisfied with their lives.

13. Reach across social networks. Secular people can be reached better by credible Christians in their kinship and friendship networks than by Christian strangers. Reach the unchurched secular people in their social networks of relatives, friends, neighbors, and colleagues. Sharing the gospel across friendship networks can produce more new Christians than any other outreach mode. We must maintain our friendships with non-Christians.

14. Offer culturally appropriate forms of ministry. Secular people, like any other people-group, are reached more effectively through the people, language, liturgy, music, architecture, needs, struggles, issues, leaders, and leadership style that are indigenous to their culture. We know that this cardinal principle of Christian mission applies to other mission fields, of course, but have not yet discovered its necessary application to our Western fields. Unchurched seekers experience our buildings, liturgies, stained-glass windows, organ music, ushers, offering plates, and "our people with their sunday faces on" as culturally alien, bizarre, and even intimidating. The barrier is not theological but cultural.

The early Church supposedly settled this matter once 
and for all. The first Church council decided that Gentiles did not have to become culturally Jewish. Many unchurched people today assume, say, that learning to pray in Elizabethan English and to enjoy eighteenth-century German pipe organ music is a prerequisite to relating to Christ. For Christianity, each people's culture is the most appropriate and potent medium for God's revelation to them. The caring Christian movement develops a contextualized church for each culture.

The extent to which the faith is likely indigenized for a given culture is most obviously observed in the Church's music and the people's spontaneous, contagious, and celebrative involvement in the music. All creative and extensive periods of church growth have been characterized by an appropriate indigenous hymnody.

The vernacular is the real test. If you cannot turn your faith into the vernacular, than either you do not understand it or you do not believe it.

15. Multiply "unites" of the Church. New units--that is, new classes, new groups, new choirs, and new congregations--will disciple more secular people than will old units, because secular people are more interested in getting in on the start of something, where everybody is "even," then in joining an established group with cliques and a fixed agenda. 
At least 70 percent of the people who join a new church join as new believers, and at least 70 percent of those converts could not have been won by established churches. As Rick Warren says, "The more hooks you use, the more fish you are going to catch!" So Saddleback Valley Community Church offers multiple services, multiple types of small groups, multiple ministries, and multiple ways of coming to Christ, because "very few people will be put on a conveyor belt today."

16. Offer ministries that meet needs. Secular people are more reachable through ministries that engage their struggles, felt needs, and driving motives. The strategy of ministering to a range of human needs is the main way that churches demonstrate Christianity's "relevance," which is necessary precisely because so many secular people assume the faith to be irrelevant to the real struggles that people and communities experience. Thus churches that develop ministries that "scratch where people itch" will engage and disciple more of them.

The available point of contact is a point of felt need. You are heard only if you are relevant. The Christian communicator will either "talk to the world as they. know it" or reinforce their assumption that Christians live in an ivory tower.

17. Engage secular people on "their turf." We must 
stay near enough to God to hear God, but not so far away from people that we do not hear them. ${ }^{1}$

In attempting to reach secular people, we must not put them down, talk down to them, or reveal to them somehow (even in body language) that we do not respect them. We need to take the time to understand where they are coming from, not acting as if we have all the answers. Most already have a measure of faith, and hunger for more. We must validate this. ${ }^{2}$

Hunter gives ten ideas that will help avoid making the mistakes mentioned in the above paragraph:

1. Active listening. Before people are ready to hear the gospel, they must have the opportunity to vent feelings that prevent a hearing of that message. Listen to them. People cannot hear until they have been heard. Do not try to "win someone to Christ" in one visit with a sequence of stock questions.

2. First engage people on neutral turf, or on their turf. Do not make your first contact in your church. Billy Graham's crusades initiate the first point-of-contact in football stadiums.

3. Relate to seekers as a friend and ally, not an adversary who is out to "win" them. Function as

${ }^{1}$ Ibid., 55-72.

${ }^{2}$ Ibid., 98 . 
"consultants" who are helping people to find faith, not as hard-sell persuaders who are talking them into believing or joining.

4. Do not try to do all the communicating. Faith is more caught than taught. Meaningful involvement helps people discover the faith for themselves.

5. Speak early to the questions, unmet needs, and unfulfilled motives that drive secular people's lives. The "point of contact" between Christianity and people is the point at which some facet of the gospel engages a pressing human need, such as how to deal with failure, disappointment, and success, and why people suffer. Begin where people are, not where we want them to be. Do not dump some theological baggage before it is asked for. Bill Hybels says that "to people who are self-deceived, there's nothing I can say. It does no good to try to convince them of their need. But publicly or privately I can offer my assistance for the day they finally realize they need Christ."

6. Communication of the Christian message's meaning takes place, by cumulative effort, over time. Do not try to communicate every jewel in the gospel treasure in one transaction.

7. Personalize the message. Speak to individuals and the "me-ness" of the gospel. There is no such thing as mass 
evangelism.

8. Do not put the pressure on for a decision.

9. There is communication value in word plays, proverbs, and other maxims.

10. Tell stories. Let the seeker discover the point for themselves. They resist biblical instruction. ${ }^{1}$

People are different; do not try to treat them all the same. Exegete the context as well as the text. ${ }^{2}$

The truth is not negotiable, but the outer forms through which it is communicated are negotiable. We must be aware of different cultures and subcultures, using them as a natural medium of communicating God's revelation. ${ }^{3}$

Robert Schuller uses the following formula:

1. The unchurched people's needs will determine our programs.

2. The unchurched people's hang-ups will determine our strategy.

3. The unchurched people's culture will determine our style.

4. The unchurched population will determine our growth goals. ${ }^{4}$

\section{Bill Hybels}

Hybels is currently Senior Pastor of the Willowcreek Community Church near Chicago. Their total church program

${ }^{1}$ Ibid., $98-106$.

${ }^{2}$ Hunter, Church for the Unchurched, 56.

'3bid., 65.

${ }^{4}$ Ibid., 71. 
is perhaps the most copied one in America. He writes:

The typical traditional church is no place for the unchurched. To anybody but the already convinced, the average church service seems grossly abnormal. It makes no sense to those who haven't grown up in it, to those who do not know the drill. The music we sing, the titles we choose, the way we dress, the language we use, the subjects we discuss, the poor quality of what we do-all of these lead the average unchurched person to say, "This is definitely not for me."1

Hybels's mission statement focuses on turning irreligious people into fully devoted followers of Christ. They have a seven-step process:

1. Build an authentic relationship with a nonbeliever.

2. Share a verbal witness.

3. Bring the seeker to a service designed especially for them.

4. Regularly attend a service for believers.

5. Join a small group.

6. Discover, develop, and deploy your spiritual gift.

7. Steward your resources in a God-honoring way. ${ }^{2}$

\section{Lee Strobel}

Rick Warren, of the Saddleback Community Church, once said that the very first step in reaching the unchurched was

'Iynne Hybels and Bill Hybels, Rediscovering Church (Grand Rapids: Zondervan, 1995), 32.

${ }^{2}$ Ibid., 170-179. 
to learn to think like them. We need to learn how to translate the gospel without transforming it. Lee strobel has dedicated his life to just that, helping irreligious people. He is presently a teaching pastor at Willow Creek Community Church.

Within two years of becoming a Christian, most of us have lost touch with people outside the faith. We forget how they think. ${ }^{1}$ Lee's wife, Leslie, found that she was baffled by Christian lingo at traditional churches, their music was outdated, and the sermon was intended for Christians and left her confused. A friend invited her to Willow Creek Church, they talked her language, and she kept attending. Lee saw positive changes in her life and started attending also. He was a skeptic (an "Unchurched Harry"). He shares six "take-away points" from his spiritual journey which ultimately led him to a growing Christian walk:

1. Evangelism is often a process, not a sudden event.

2. Unchurched people are willing to visit a church if they're invited by a friend who has already opened up spiritual issues through personal conversations.

3. Women can have a significant influence with men on religious issues.

4. In trying to reach a friend with the Gospel, even

\section{${ }^{1}$ Lee Strobel, Inside the Mind of Unchurched Harry \&}

Mary (Grand Rapids: Zondervan, 1993), 15. 
mature Christians often need to partner with a church that offers services or periodic events that are sensitive to seekers.

5. "Apologetics," or using evidence and reasoning to defend the faith, is critically important in penetrating the skepticism of many secular people today.

6. Many irreligious people avoid church because of negative church experiences they had as a child. However, these biases can be overcome if a church thinks through the way that it will be perceived by unchurched visitors and then shapes its ministry accordingly, without altering the Gospel. ${ }^{1}$

Strobel gives fifteen observations in understanding the unchurched:

1. Harry has rejected church, but that doesn't necessarily mean he has rejected God. He often is a "religious" person, interested in spiritual matters, but is turned off to the organized church because he sees it as an archaic and irrelevant institution. Really, only about 13\% of Americans are atheists or agnostics. Many unchurched people consider themselves to be Christians. They believe in God, they do not believe in church. Hostile to the church, friendly to Jesus Christ. 91\% of non-Christians believe that the church isn't very sensitive to their needs. ${ }^{2}$

2. Harry is morally adrift, but he secretly wants an anchor.$^{3}$

3. Harry resists rules but responds to reasons. He doesn't like to be told what to do. He recoils when people tell him that he ought to live a certain way because the Bible says he should. He

${ }^{1}$ Ibid. , 42-43.

${ }^{2}$ Ibid. , 45-47.

${ }^{3}$ Ibid., 47. 
wants to see the wisdom behind changing his ways, not just a "thus saith the Lord."

4. Harry doesn't understand Christianity, but he's also ignorant about what he claims to believe in. $\mathrm{He}$ is a Christianity illiterate. Most Americans cannot even name the four gospels; six out of ten do not know who delivered the Sermon on the Mount. One of the most effective evangelistic approaches I've learned is to ask Harry to describe what he believes about God, and then let him talk. And talk. And talk. And I listen. ${ }^{2}$

5. Harry has leqitimate questions about spiritual matters, but he doesn't expect answers from Christians. He looks at churches and imagines a sign out front that says, "No questions allowed." When you're interacting with Unchurched Harry on an individual level, the manner in which you respond to his questions is extremely important. Many times, the first question he raises is sort of a "trial balloon." He wants to see whether you'll laugh at him, belittle him for his ignorance, . . or takes the question seriously. ${ }^{3}$

6. Harry doesn't just ask, "Is Christianity true" often, he's asking: "Does Christianity work?" Kids these days aren't asking, "What's true." Today kids are asking, "What can help me deal with my pain?" Christianity isn't just for the tomorrow of his eternity but also for the today of his life.

Baby Busters have learned to expect that their needs should be met, jobs would be provided, money would be available, and problems would be solved. The result is a generation of young adults who want and expect everything right away. Life is to be lived for the present. They want to hear about a faith that works now and brings immediate results.

Christians need to continue to marshal the

${ }^{1}$ Ibid., 49-50.

${ }^{2}$ Ibid., 53.

${ }^{3}$ Ibid. , 54-55. 
historic, archaeological, prophetic, and other evidences that Jesus is the one and only Son of God. But we shouldn't stop there. We should be ready to go the next step and tell Harry that because that's true, there are meaningful implications for his life today-for his marriage, his friendships, his career, his recovery from past pain, and so on. ${ }^{1}$

7. Harry doesn't just want to know something; he wants to experience it. Experience, not evidence, is his mode of discovery. The object of evangelism should be to bring Unchurched Harry into a personal encounter with God, not just to merely pass on information about God. ${ }^{2}$

8. Harry doesn't want to be somebody's project, but he would like to be somebody's friend. Introducing small groups into a church can create great opportunities for Christians to go deep with each other.

Harry's attitude softens considerably when he sees the church not as an institution but as a caring community where his relational longings can be fulfilled. ${ }^{3}$

9. Harry may distrust authority, but he's receptive to authentic biblical leadership. He'll respond positively to those who are accountable, humble, modest about their achievements, help those in need. ${ }^{4}$

10. Harry is no longer loval to denominations, but he is attracted to places where his needs will be met. The days of brand loyalty are largely over. Now denominational loyalty is faltering, too. Implications:

a. Do not count on denominational ties to get him back to church. He'll respond better to

\footnotetext{
${ }^{1}$ Ibid., 57-59.

${ }^{2}$ Ibid., 59 .

${ }^{3}$ Ibid. , 60-63.

${ }^{4}$ Ibid., $65-66$.
} 
an invitation to a specific program or event that will meet his needs.

b. Consider dropping the denominational affiliation from their names, in certain instances. Some start using "community church." c. Guard against reliance on traditional modes of ministry and instead free up members to pioneer cutting-edge programs tailored to Harry's specific needs.

d. Traditional congregations should be nudged toward being more "seeker friendly" in their worship and to develop appropriate periodic outreach events and special services where their members can bring unchurched friends.

e. Blurring the line between laity and "professional" ministers would be a positive development to Harry.

f. Values that attract Unchurched Harry are excellence, creativity, authenticity, relevance, meaningful participation by the laity, and servant leadership.

g. The attitude, "That's the way we've always done things" needs to become, "What can we do better to meet more needs and reach more people with the Gospel?"1

11. Harry isn't much of a joiner, but he's hungry for a cause he can connect with. Harry is interested in an institution through which meaningful social change could be accomplished. Churches need to be more involved in their community. For some unchurched people, the idea of church membership strikes them as negative. "Why do they want me on a roster somewhere?" ${ }^{2}$

12. Even if Harry's not spiritually sensitive, he wants his children to get quality moral training. ${ }^{3}$

13. Harry and Mary are confused about sex roles, but they do not know that the Bible can clarify for them what it means to be a man and woman. Men

\footnotetext{
${ }^{1}$ Ibid. , 66-69.

${ }^{2}$ Ibid. , 69-71.

${ }^{3}$ Ibid. , $72-74$.
} 
aren't sure what masculinity is anymore. Men's retreats can help. Mary needs to see churches that are addressing her felt needs and relating to her world, such as ministries specially geared for working women. ${ }^{1}$

14. Harry is proud that he's tolerant of different faiths, but he thinks Christians are narrowminded. He doesn't like value judgments on which faith is right or wrong. ${ }^{2}$

15. There's a good chance Harry would try church if a friend invited him-but this mav actually do him more harm than good. What will he find when he comes to church? Churches need to create services or outreach events that will meaningfully connect with the unchurched mind set. ${ }^{3}$

Strobel posits a seven-step strategy for reaching unchurched believers:

1. Believing Bob builds an authentic relationship with Unchurched Harry.

2. Believing Bob tells Unchurched Harry how God has changed his life and, to the best of his ability, seeks to communicate the Gospel over time.

3. Believing Bob invites Unchurched Harry to a service designed for seekers and answers his questions and concerns.

4. Once Harry commits himself to Christ, he begins attending a worship service geared for believers.

5. Harry joins a small group designed to help him. grow spiritually.

6. Harry discovers, develops, and deploys his spiritual gift in order to honor God and to build

$$
\begin{aligned}
& { }^{1} \text { Ibid., } 74-77 . \\
& { }^{2} \text { Ibid., } 77-79 . \\
& { }^{3} \text { Ibid., 79-81. }
\end{aligned}
$$


the church.

7. Harry begins stewarding his resources-time and money-in a godly fashion. ${ }^{1}$

Unchurched people's number-one value is anonymity. ${ }^{2}$ They dread being placed on a mailing list, ${ }^{3}$ prefer small groups," they like "exciting, insightful, daring, creative, awe-inspiring and celebratory" worship services. ${ }^{5}$ Organ music is out--music leaders need to utilize what is selling in music stores. ${ }^{6}$

They are connected with the TV generation. They crave visual stimulation. ${ }^{7}$ Print is out; many do not even read. Linear thinking is out; experiential is in. The more senses used in reaching them, the greater the impact. ${ }^{8}$ Quality counts; they expect excellence. ${ }^{9}$ When asked what could bring them into a church, the number-one response was

\footnotetext{
${ }^{1}$ Ibid. , 165-166.

${ }^{2}$ Ibid., 171 .

IIbid., 174.

${ }^{4}$ Ibid., 175.

${ }^{5}$ Ibid., 179.

${ }^{6}$ Ibid. , 180-181.

'Ibid., 182 .

${ }^{8}$ Ibid., 187.

'Ibid., 190-191.
} 
"better messages."1

A recent Gallup Poll showed that "too much concern for money" was the number-one reason given for why people abandoned church. ${ }^{2}$

\section{Leith Anderson}

Anderson is currently Senior Pastor of Wooddale Church in the Minneapolis suburb of Eden Prairie, Minnesota. He is known nationally as an author, speaker, and educator.

He writes in his book Dving for Change that an estimated 85 percent of America's Protestant churches are either stagnating or dying. ${ }^{3}$ The communicator must make the Bible relevant to be heard. ${ }^{4}$ The church has the responsibility to understand both the people and the culture in which they live. The Bible must be made relevant to today's culture. ${ }^{5}$

There are many changes in our country, such as

${ }^{1}$ Ibid., 211.

${ }^{2}$ Ibid., 206.

${ }^{3}$ Anderson, Dying for Change, 10 .

${ }^{4}$ Ibid., 15.

${ }^{5}$ Ibid., 17. 
greater mobility, ${ }^{1}$ the coloring ${ }^{2}$ and graying ${ }^{3}$ of America, and women assuming greater access to traditionally male positions. ${ }^{4}$ Pluralism, so many choices, and a shift from absolute to relative values are rampant. ${ }^{5}$ Christians have less common ground with the unchurched.

The rise of consumerism and consumer advocacy is the greatest factor in denominational decline. ${ }^{6}$ People shop around now for the church that meets their needs. They are not loyal to a particular denomination or neighborhood church. People are more loyal to a particular minister. We must change the starting point of evangelism. People used to have some kind of religious background and were familiar with basic Christian ideas and vocabulary. That landscape is rapidly changing. Millions of Americans have never been to church, never cracked a Bible, have no interest in or sense of need for religion. We must go to them, attract them, start where they are instead of where we

$$
\begin{aligned}
& { }^{1} \text { Ibid., } 26-27 . \\
& { }^{2} \text { Ibid., } 28-29 . \\
& { }^{3} \text { Ibid., } 29-30 . \\
& { }^{4} \text { Ibid., } 30-31 . \\
& { }^{5} \text { Ibid., } 31-32 . \\
& { }^{6} \text { Ibid., } 49 .
\end{aligned}
$$


wish them to be. ${ }^{1}$

Today's churches must be open to new ideas and changing structures, realizing that many areas are cultural relatives, not moral absolutes. Yesterday's answers may not be appropriate for today's mind-set. Fulfilling our mission supercedes perpetuating traditions. ${ }^{2}$

Balanced with that, we must remember the lessons of the past (heresies, failures). There are absolute truths that supercede private preferences. Secular values must not be allowed to take root and grow in the church, or they will endanger the continuation of biblical standards of truth and practice. ${ }^{3}$

There is a growing polarization among evangelicals. In one camp are clustered the monastics--those who stick to "truth and tradition." Yet they are isolated from society. In the other camp are clustered post-Christian secularists, sociologically relevant but no longer truly Christian. ${ }^{4}$ Anderson suggests six organizational responses to change:

\footnotetext{
IIbid., 133-134.

'Ibid., 136.

'Ibid., 137.

${ }^{4}$ Ibid.
} 
1. The Resistant Church is conservative in the purest definition of conservatism; that is, they want to keep things the way they are. Not all resistance is rooted in moral principle. Much resistance is the result of personal and institutional insecurity-a fear of change which results in isolation. The resistant church is seldom an evangelistic church. ${ }^{1}$

2. Yesterday's Church keeps hoping that tomorrow will be 1954. When the building is refurbished, it is in a style befitting the golden era. Music, liturgy, sermon topics, Bible version, literature, social activities, and management are as close to the old days as possible.

There is no going back. Christianity cannot be constructed on fleeting nostalgia. Yesterday's Church will eventually die from the terminal disease of obsolescence. ${ }^{2}$

3. The Try Harder Church is devoted to doing the same things better rather than trying to be better by doing different things.

Today Sunday school may be the last program a newcomer joins. Entry points are special interest groups, weekday activities, Christmas Eve services, athletic programs, and Sunday worship services. The popular prophecy conferences of the 1960 s and 1970s do not attract much interest in the 1990s. Instead, baby boomers are drawn to conferences teaching on marriage and the family.

It is painful to see well-meaning people give themselves and their resources to improving and promoting products few customers want. It is a little like selling prettier manual typewriters to a market that wants word processors. ${ }^{3}$

4. The Surrender Church truly understands itself and its relationship to modern society; and on the basis of this understanding, it concludes that it cannot change, will not change, or is simply being

\footnotetext{
${ }^{1}$ Ibid. , 140-141.

${ }^{2}$ Ibid., 141-142.

${ }^{3}$ Ibid. , 142-143.
} 
swept away by change.

If it changes to meet the needs of its young people, the old will be abandoned. Many choose to lose the young, continue to serve the old, and eventually close-having served one generation well and leaving the next generation to the care of others. Change forces a continual evaluation of what is essential and what is not. ${ }^{1}$

5. The Entrepreneurial Church is founded by capable charismatic leaders who see a need and venture to meet it. Bill Hybels asked people what they wanted or didn't want in a church [similar to Schuller], and out of their responses developed a program targeted to the unchurched- with practical and relevant sermons, drama, contemporary music, minimal mention of money, and many special

programs for meeting specific needs.

They are market-sensitive, highly relational, not usually affiliated with a denomination, and they play-down tradition. There may be cause for great concern. Many of the pastors in these churches are not theologically trained. Often there is no connection with the past. Lack of tradition, theological training, and denominational accountability increase the potential for doctrinal heresy and immorality. ${ }^{2}$

6. The Renewing Church is established and stable and willing to capitalize on that stability in an ongoing quest for relevance. This church values both tradition and change and makes an effort to know theology and sociology, to be faithful to orthodoxy and practical to people. Renewal is ongoing in this church. There is never a sense of satisfaction or arrival. Systems are set in place for regular evaluation and modification, and everything is open to question. Change for change's sake may actually be welcome in order to keep the organization flexible enough to change in the future when it is essential. ${ }^{3}$

\footnotetext{
${ }^{1}$ Ibid. , 143-144.

'Ibid., 144-146.

IIbid., 146-147.
} 
A local church needs to learn the market, do a demographic study, and mold its ministry to a target population. Decide on the nonnegotiables. They are directly from God; everything else is negotiable. Changes must fit both the purpose and the market. ${ }^{1}$

Successful traditional churches will need to incorporate many contemporary elements, including services to consumers and meeting modern needs. They will need to do the traditional with a high level of excellence. ${ }^{2}$

To many older Christians "contemporary" means new, and they do not like it. To many younger Christians "contemporary" means new, and they do like it.

Contemporary, however, is merely a contrast to traditional. It means that it originated during the present generation rather than inherited from a previous generation. It is not better or worse; it is just later. ${ }^{3}$

The essential exercise for every church leader is to first understand the culture and then translate the meaning of the message into that culture. ${ }^{4}$

Anyone who thinks that a different style of worship

\footnotetext{
${ }^{1}$ Ibid., 164-167.

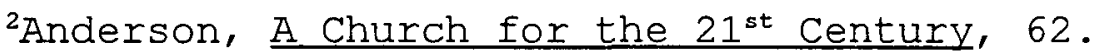

${ }^{3}$ Ibid. , 148 .

${ }^{4}$ Ibid., 149 .
} 
service makes a contemporary church has missed the mark. That would be like installing a hot tub in an outhouse and calling it modern plumbing. It is a lot more complicated. Contemporary churches are those that relate to people in terms of today's culture rather than in terms of yesterday's traditions. Neither today's culture nor yesterday's traditions are necessarily right or wrong. ${ }^{1}$

Yesterday's style (sermon) was oratorical, formal, loud, polished, intense, used significant historical illustrations, and told people what to do. Today's style is much more conversational, much like the monologue of Johnny Carson or Jay Leno on the "Tonight Show." Tom Peters says, "The whole issue with public speaking at any level is loosening up and getting comfortable." Today's speaker is more of a "communicator" than" a "preacher." Today's style is more of a "conversation" that a "lecture."

\section{George Barna}

Barna is founder and president of Barna Research Group. He has conducted extensive research for many corporations. $\mathrm{He}$ is in wide demand as a speaker on how the church can meet the challenges of the future. He has written several books.

\footnotetext{
${ }^{1}$ Ibid., 152 .

${ }^{2}$ Ibid., 208-209.
} 
One of my favorites is The Frog in the Kettle.

The signs we need to perceive are not vague predictions about the future-many are present realities. The trouble is that they occur so gradually that we often do not notice them. It's like the familiar story of the frog and the kettle of water. Place a frog in boiling water and it will jump out immediately because it can tell that it's in a hostile environment. But place a frog in a kettle of room-temperature water and it will stay there, content with those surroundings. Slowly, very slowly, increase the temperature of the water. This time, the frog doesn't leap out, but just stays there, unaware that the environment is changing. Continue to turn up the burner until the water is boiling. Our poor frog will be boiled, too-quite content, perhaps, but nevertheless dead.

The Christian community in America might be expected to be more aware of current changes in the environment than the frog in the kettle. Yet, for the past two decades, at least, the Church has been generally insensitive to those changes. We have continued to operate as though our environment has remained the same. Like the frog, we are faced with the very real possibility of dying because of our unresponsiveness to the changing would around us. ${ }^{1}$

Many Christians in England warn that we are undergoing in this country a rise in the "temperature" of our spiritual environment much like they experienced in their own land.

These observers recall when England was a nation in which the Church was the central institution of society. Moral values, social behavior, cultural activities, family development, lifestyles, and even political decision-making

${ }^{1}$ George Barna, The Frog in the Kettle: What Christians Need to Know about Life in the Year 2000 (Ventura: Regal Books, 1990), 21-22. 
all revolved around the nations's religious perspective and spiritual sensitivity.

More recently these values have been undermined by the encroachment of secularism. There is more concern now for the material than for the spiritual. True believers are estimated now to be only about 2 percent of the population. ${ }^{1}$

The Christian community, in the midst of a whirlpool of change and a hostile societal environment, is losing the battle. Charged by Christ Himself to be agents to change the world rather than agents changed by the world, we have been mesmerized by the lures of modern culture. Rather than prepare for the coming battles, we revel in past victories, focusing on what can never be changed or relived, at the expense of tomorrow's opportunities. Change is now a constant in America. ${ }^{2}$

The old approaches and traditional strategies for sharing our faith will no longer work in this new century. We have to be clever enough to analyze our environment and provide creative responses to the challenges we face.

Typically, we have been five to ten years behind society, responding to changing conditions long after transitions have begun. And now we have run out of time.

${ }^{1}$ Ibid., 22.

${ }^{2}$ Ibid., 23. 
If we want the Christian faith to remain a vibrant alternative to the world system, we must stop reacting and start anticipating. ${ }^{1}$

We must keep in mind Paul's suggestion that we must be sensitive to our culture, adapting our approaches without compromising our message. America's superficial spirituality demands that we rededicate ourselves to proclaiming the gospel in new ways that are relevant to people's lives. ${ }^{2}$

It will be increasingly difficult to convince the unchurched that our faith is pertinent to the twenty-first century if the tools of our trade are from the last century ${ }^{3}$

Churches must base their ministry upon the felt needs of the audience. Yet one of the glaring weaknesses of the Church has been in the area of discipling and accountability. We will be tempted to downplay the importance of commitment and obedience. We will be tempted to soften the truth so that a hardened generation will give us a fair hearing. There is a fine line between clever marketing and compromised spirituality.

\footnotetext{
${ }^{1}$ Ibid., 26.

${ }^{2}$ Ibid. , 27-28.

'Ibid., 29.
} 
Does this mean we should not attempt to repackage the gospel in ways that may be more attractive to nonbelievers? No? We must do so if we hope to get our message to emerge from the flood of commercial messages that are directed at us each day. Our goal, however, must be to describe the faith in ways which are clearly relevant to today's circumstances and tensions, but without minimizing the hard truths that Jesus taught and demands of us. In a society that does not recognize absolutes, we must make absolutes seem not only relevant but natural and appealing. ${ }^{1}$

The best way to get the unchurched or nonbelievers to consider the church valid and worthwhile is by making ourselves relevant to their lives. We must understand and respond to their most pressing felt needs. ${ }^{2}$

Most of all, we must show nonbelievers what it looks like to be at peace with ourselves, and to truly love other people. The best means of creating an interest in Christ and the Christian way of life is to so thoroughly live and enjoy it that others will want to know how they, too, can have it.

Survey data show that most Americans believe that you cannot tell a born-again Christian from nonbelievers because

\footnotetext{
${ }^{1}$ Ibid., 123-124.

${ }^{2}$ Ibid., $146-147$.
} 
there is no difference in the way they live. The only distinction, people say, is that Christians are more religious, more fanatical, or more close-minded. ${ }^{1}$

\section{William M. Easum}

Easum is currently director of $21^{\text {st }}$ Century Strategies. He travels extensively as a full-time church consultant.

In the chapter "Bursting Wineskins and Munching Sheep," Easum tells a parable about a woman who owned the finest winery in all the land. One day the wine developed a bitter taste. Experts told her the vats had outlived their usefulness. They were old and sour, with no way to be refurbished. They needed to be replaced.

She was outraged. The vats had been in her family for decades. Family tradition ran too deep to replace the vats.

The wineskin (see Matt 9:17ff.) is the church. For two centuries North American congregations swiftly and efficiently spread the good news across this vast continent offering the grace of God to every part of North America. Today, many of these congregations are becoming irrelevant to a hurting unchurched world and are unable to offer new wine to the new generation.

This parable announces a warning to churches that look

${ }^{1}$ Ibid., 167. 
to the past and ignore the transitional signs all around them. God is calling us to find new ways to apply the good news to a new emerging world. Our churches often fail to quench the thirst of a spiritually dehydrated world. Churches with a slow pace of change are no longer adequate in a fast-changing world. Ministries that worked in the industrial society no longer meet the spiritual needs of people in an informational society. In an age of computers, we cannot express truth in the language of a chariot age. The time has come for new wineskins.

Developing new wineskins requires that we learn a new language, understand new customs, and find new ways to make the timeless gospel relevant to our culture. And we must do so without diminishing the use of the word Christian, even in our pursuit of inclusiveness or ecumenism. ${ }^{1}$

Easum does not want to change the substance of the gospel, merely its packaging. A few adjustments will not suffice. If we continue with our irrelevant packaging, the church will, in time, grow extinct. ${ }^{2}$

We must stop refusing to change our methods and structures and start ministering to people where they are in

\footnotetext{
${ }^{1}$ Easum, Dancing with Dinosaurs, 11-13.

${ }^{2}$ Ibid., 14 .
} 
ways they can understand. ${ }^{1}$ The fastest way to fail is to continually improve on yesterday's successes.

Small-group ministries are replacing programs.

Congregations who use them will remain healthy; others will die out. ${ }^{2}$ This transition from program-based to smallgroup-based ministry is the most fundamental paradigm shift in the history of North American Christianity. ${ }^{3}$

Small groups perform almost all of the traditional roles played by the pastor in the program-based model: counseling, evangelism, and new member assimilation. ${ }^{4}$

Effective worship is culturally relevant; it grows out of the culture of the area. The style and form are comfortable to those attending worship from the nonChristian world. The message remains the same, but the packaging is culturally relevant. ${ }^{5}$

Music is the major vehicle for celebration and communication; it is the vehicle through which most unchurched people experience worship. The type of music that reaches people comes out of their culture. Soft rock

\author{
${ }^{1}$ Ibid., 15 . \\ ${ }^{2}$ Ibid., 58 . \\ ${ }^{3}$ Ibid., 60. \\ ${ }^{4}$ Ibid. \\ ${ }^{5}$ Ibid., $81-82$.
}


is the music of the majority of unchurched people in America. Only 4 percent of the records sold in the U.S. are classical. ${ }^{1}$ It is the ritual of our time, the vehicle or conduit through which the message is conveyed. It is not unusual for music to comprise 40 percent of worship in culturally relevant churches. ${ }^{2}$

Spiritual giants such as Martin Luther and Charles Wesley showed us the importance of culturally relevant music. They met the needs of the culture of their day by taking the tunes out of bars, putting words to them, and using the songs in worship. They accommodated the needs of people in order to reach them with the message that would eventually change their lives. They did not conform the message, just the package.

Synthesizer, drums, flute, electric guitar, tambourine, bass, and piano are the basic instruments of today. A culturally relevant worship center must include a quality sound system with these instruments, microphones, monitors, a sound engineer, and good acoustics, as well as lighting and large projection screens.

Hymnals are often discarded or supplemented with praise choruses that reflect contemporary tastes in music. The

${ }^{1}$ Ibid. , 84 .

${ }^{2}$ Ibid., 85 . 
words to the songs are displayed on a large, elevated screen. People look up and around instead of burying their faces in a hymnal or looking down at their feet. ${ }^{1}$

One study of Southern Baptist churches revealed that the quality of the contemporary music is one of the strongest factors in church growth, regardless of size. ${ }^{2}$

Changing music habits of declining or stagnant congregations is proving to be a major source of conflict. Two styles of worship are needed in churches that have reached their plateaus or are declining. Aged congregations will not give up their style of worship; younger generations do not enjoy worship in the culture of the older generation. ${ }^{3}$

Entertainment is an integral part of contemporary evangelism. Music and drama are a major form of reaching out to the unchurched. Effective preaching makes a passionate appeal to the emotions more than fact, thereby painting a visual picture of the subject. ${ }^{4}$

Worship is casual; suits and ties are not essential to the "jeans generation." Buildings are not important;

\footnotetext{
IIbid., 86.

${ }^{2}$ Ibid.

${ }^{3}$ Ibid., 87-88.

${ }^{4}$ Ibid., 90-91.
} 
denominational identity is avoided in advertising. ${ }^{1}$

Weekday ministries overshadow the importance of sunday. In fact, more people participate during the week than on Sunday. The social needs of Christians are being fulfilled within the Christian community. Single adults will be the largest weekday mission field in the twenty-first century. ${ }^{2}$

Weekday Bible studies and retreats are reducing the prominence of Sunday schools. Between 1970 and 1990, Sunday school participation in mainline denominations declined by 55 percent. People today demand a seven-day-a-week community of faith. In time sunday school may disappear. ${ }^{3}$

In short, the critical difference between healthy, growing congregations and other churches is not some secret formula for success. Their distinguishing feature is that they do the common, mundane, boring tasks of ministry uncommonly well. They do so regardless of their size, socioeconomic makeup, location, or environmental changes.

This passion for excellence starts with the role modeling of pastors. It is the basic ingredient to their vision. ${ }^{4}$

İbid., 91-92.

${ }^{2}$ Ibid.

${ }^{3}$ Ibid. , 100-101.

${ }^{4}$ Ibid., 111 . 
We must study sociology more than theology. We must learn how people think and feel and how systems operate. ${ }^{1}$

In his book Sacred Cows Make Gourmet Burgers, Easum lists several characteristics of the sacred cow (immune from criticism) of control:

1. "We've never done it that way before."

2. "We tried that before and it didn't work."

3. "No one does THAT in this church."

4. "We do not do things that way."

5. "It's too radical a change for us."

6. "If only it were that easy."

7. "When you've been around longer, you'll understand why it cannot be done."

8. "How dare you criticize what we're doing."

9. "We've been running this church since long before you were born."

10. "Who gave you permission to change the rules?"

11. "What you're suggesting is against our policies."

12. "Our church law will not let us do that."

13. "Will not that open us up to liability?"2

He describes a church that had a yo-yo worship attendance. The membership's average age was sixty; the average age in the community was thirty-five. He suggests the solution is to add a second worship service designed to reach unchurched people between thirty and forty years of age. ${ }^{3}$

Yes, "control" is the Sacred Cow of established

${ }^{1}$ Ibid., 113-114 .

${ }^{2}$ William M. Easum, Sacred Cows Make Gourmet Burgers: Ministry Anytime, Anvwhere, By Anvone (Nashville: Abingdon Press, 1995), 11.

${ }^{3}$ Ibid., 12 . 
churches, and it needs to be ground into gourmet hamburger. ${ }^{1}$ Instead of encouraging churches to gradually change an existing service, he encourages them to begin an alternate service designed for people born after World War Two. Thus, no changes have to be made in the existing service, producing a "win-win" situation. ${ }^{2}$

People born after 1950 are creating a new way of organizing through their emphasis on relationships and computers. Churches that want to reach them must design organizations that emphasize relationships and networks instead of a chain of command. They must stress mentoring and self-organizing, instead of bossing. They must be comfortable with complexity and paradox instead of the status quo, and see time, space, and matter as resources instead of constraints. The more intent a church or denomination is on reaching the unchurched in the twenty-first century, the more it will abandon bureaucracy in search of a new method or organizing for ministry. ${ }^{3}$

${ }^{1}$ Ibid., 15.

'Ibid., 31.

Ibid., 101. 
CHAPTER FIVE

SYNTHESIS AND EVALUATION OF MATERIAL

\section{Chapter 2}

Chapter 2 provides a brief definition of secularism with a sampling of four sources. Paulien, the "Committee on Secularism," Finley, and Hunter suggest that secular people tend to rule out God as acting in history. Humans control what goes on, and they act from their environment and heredity.

Paulien and the "Committee on Secularism" state that a secularist believes that everything is relative; what is right depends on the contemporary situation.

According to Paulien, the "Committee on Secularism," and Hunter, the secularist believes this life is all there is. The afterlife is wishful thinking, nothingness. They want life before death.

Whereas Paulien articulates that the secularist is not an atheist, the "Committee on Secularism" portrays a godless universe. Finley and Hunter rightly suggest that there are various brands of secularism, some allowing God in their 
world-view, while others completely ignore the idea of God. Finley's "religious dropout" category coincides with Hunter's position that secular people have a negative image of organized religion. The Church is not seen as relevant.

I found Paulien's and Finley's description of secularism to be somewhat simplistic.

The next section traces the origin and development of secularism, starting with the OT biblical period. In the biblical and patristic periods, God was seen as actively involved in nature and human affairs. Hellenization with its reliance on reason over revelation started eroding people's confidence and dependance on God.

During the Middle Ages, the pendulum swung back to almost absolute dependance on and preoccupation with God and the afterlife. God was seen as the active and almost sole causative Agent in history. Humans were basically God's puppets. Human affairs were marginalized, belittled, and ignored.

The Renaissance followed with its focus on a more rational basis for viewing and interpreting reality. Humanism made humanity the measure of all things, and God was secondary at best. Humanism became the engine that drove God out of day-to-day life. Human values eclipsed religious belief. Reason trumped faith. Life on earth, the here-and-now, became paramount. This was the "age of 
rationalism," "the enlightenment."

The Protestant Reformation further eroded the Church's influence by dividing the church and turning its attention away from societal concerns and inward toward renewal and theological matters.

The rise of Nationalism undercut the understanding of a common humanity that had prevailed in Christendom. The rise of Science challenged Christendom's pre-scientific assumptions about the universe and human life.

Urbanization is the Siamese twin of secularization. The vast urban centers with massive man-made structures dim our consciousness of God. Cox's three stages in the process of secularization (tribal, town, and technopolis) add credence to this view that urbanization is the final stage of the secularization process.

Humanism gave rise to secularism, where otherworldliness is secondary at best and outright ignored at worst. The Church's response further eroded its influence by its pathological pattern of responses to the above events. Its credibility was compromised, and people could see through its paranoia.

Paulien suggests three major influences that drive secularism: science, pluralism, and privatization. Decisions are made relying on the scientific method instead of consulting a Higher Power. No one religion is better 
than another. It is deemed inappropriate to talk about religion in the public arena, i.e., "it is a personal matter."

The next section deals with "Secularism in the SDA Church." Paulien suggests that because many SDAs look at so much television, they may be more secularized than most Christians. He gives six ways in which SDAs become secular (neglecting private prayer, decrease in study life, eroding of personal standards, attend church less, begin to doubt the Bible, increasing distrust of institutions).

The SDA Committee on Secularism also believes that the SDA church has experienced secularization. They list several ways where its effects have been felt. We now turn our attention to Chapter 3.

\section{Chapter 3}

Chapter 3 gives an overview of biblical and SDA literature on reaching the secular mind. God wants us to reach all people-groups. He wants a house of prayer for all peoples. The gospel must be preached to all the world before the end will come. There are Gentiles who will listen. They are fellow heirs and fellow members of the body.

In reaching the secular mind, preaching Christ must be primary. We must not rely alone on highly creative technology, fancy worship service design, brilliant 
preaching, and magnetic personalities to spread the gospel. We must spread Christ through these methods; Christ must always be the focus of our communication.

Our message must be practical. We must not make the same mistake that the Middle Ages Christian did by ignoring earthly issues and needs. Jesus said that the separation of the sheep and goats would be based on whether a person was giving practical help to others in need. People will be more receptive to Christianity after we first meet their needs. Jesus' parables show that He was keenly interested in lost people (the lost sheep, a lost coin, the lost son). The parable of the sower describes different kinds of soil. The seed that fell on the "good ground" germinated in different proportions, some a hundredfold, some sixty, and some thirty. We must not expect all seed falling on good ground to germinate 100 percent.

Jesus compared spreading the gospel with fishing. At times He used a hook (one-on-one evangelism), other times He used a net (group mass evangelism) in His illustrations. The practice of catching fish and effectively sharing the gospel have several common characteristics.

The parable of the cloth and wineskins beckons us to be open to new methods of sharing Jesus.

Christ's interviews with Nicodemus, the Samaritan woman, and the rich young ruler underline the importance of 
varying our approach depending on each individual.

Selected biblical passages on effective methods of evangelizing people tell us that home meetings were utilized often. Perspective members were given only as much information as they were able to understand. At times church planting was needed instead of trying to convince "old timers" to change their traditional beliefs and practices.

Christ's followers were sensitive to each local culture. They practiced relational ministries; they realized the importance of developing a personal relationship with perspective members. The believers invited unbelievers over to their homes for fellowship. The believers accepted invitations to unbelievers' homes.

The early Christians realized the utmost importance of being in the world, of taking an active part in their communities. They worked toward making this world a better place.

At the same time, the New Testament Christians guarded themselves against being stained by the world. They did not conform to the world; they did not participate in worldly deeds. They did not marry unbelievers in an attempt to win them to Christ.

Although they experienced new freedom in Christ, they did not turn it into an opportunity for the flesh. 
The next section deals with Adventist material on reaching the secular mind. Ellen White, along with seven other SDA authors, is cited. White states that we must utilize Christ's methods of working with people in order to win them to Him. He presented the blessings of the gospel in the most alluring terms, in the most attractive way. He specifically attempted to excite the hearer with a desire to possess His blessings. In order to do this, we need to attend to how secularized people think, what interests them, and what is important to them. We must speak to them in their heart-language.

We need to teach our members the best ways to approach both individuals and families. Christ varied His messages to suit His audience. The way we present the truth has a great deal to do with whether it will be accepted or rejected. Jesus surprised people with illustrations that won their attention. He talked about practical daily life issues; He appealed to their imagination; He used figures and parables.

We must vary our labor to meet the people where they are in their life-journey. We must accommodate to their varied conditions.

Christ positioned Himself in population centers and along vital trade routes. We need to be visible in the great centers of tourist traffic. 
Change must not be feared but expected. New methods must be introduced. We must arrest the attention, at times doing something out of the common course of things.

We need to utilize a simple direct manner, using simple language. We must not bring up points on which we disagree at the beginning of our relationship. Cutting remarks repel people.

We must meet people's needs first. Christ is to be our text. We must be careful not to repeat falsehoods but hold to the truth.

Christ's work was made up largely of personal

interviews. A relational ministry was His preferred method and it must be ours to be most effective in ministries.

our religious meetings can become very formal, unpleasant, unattractive, and to the youth most burdensome. The prevailing monotony of religious services must be disturbed.

In balance, unity must be preserved. Sins must be pointed out, and practical godliness must be enforced. Our association with worldly people must be to win them to Jesus.

Paulien advances that we must contextualize the gospel in light of the prevailing secular culture. SDA churches need to be educated about their own secularization. Our members need to have contact with secular people; they 
should be encouraged to enter professions that influence the secular world.

The starting point is applying a specific gospel solution to a felt need. Simply listening to secular people is often effectual in reaching them. Relational modalities (fellowships, intimate small groups, one-on-one settings) eclipse the former proclamation model.

In our worship services we need to discard SDA jargon, preserve guests' anonymity, and be predominantly visual.

Sahlin talks of the three eras of Adventist evangelism (prophetic, institutional, and relational). Today we need to emphasize our personal faith journey more than doctrine. Friendship is the primary tool of evangelism today. We must focus on people's needs rather than institutional programs.

Cox adds the concept that we must meet people where they are. It must be a "grass roots" effort. They must be met in their home, on their street, in their workplace.

Einley directs that we should spend 70 percent of our time with the 30 percent of people who are receptive to a direct spiritual appeal. The remaining populace can be met only by programs that meet their felt needs. This mandate seems out of place in today's market. I do not think the New Testament Christians plugged that maxim into their evangelism strategy. They went everywhere. Most of the world populations knew nothing of Christ. The entire world 
was almost all virgin territory. That state exists today. Matthews points out that Christ first earned the right to be heard by addressing felt needs. He answered their questions in terms and tones that they understood. Matthews suggests that in reaching others, we must always ask, "Are we doing them any good?" The focus must not be on what the institutional church will get out of it. ${ }^{1}$

Matthews rightly suggests that we need to apply market analysis strategies in reaching all people groups. We have become exclusive and restrictive, channeling virtually all of our Adventist material to a small percentage of people who think about church. We need to funnel more church funds to minister to people who remain largely untouched by our message. This goes directly against Finley's suggestion that we spend only 30 percent of our time and resources to those less receptive to our message, i.e., "the secular person."

Matthews agrees with Paulien that we need to listen to people before we act, answering questions that they are actually asking.

Day harmonizes with Matthews in stressing strategic marketing in effective evangelism. We must start with the customer. We must market, not sell, Adventism. The

${ }^{1}$ This is similar to Sahlin's second era of evangelism, "institutional evangelism." 
marketer knows and understands the customer so well that the product fits and sells itself. People buy products that satisfy their felt needs. They buy solutions to their everyday problems.

We have asked people to become like us; then they will appreciate what we are all about. We have had it backwards. Marketing is everybody's business, not merely the pastor's.

Beach advocates that we use more music, drama, and audience participation in our worship services. Dialogue and participation are far more interesting than monologue and exhortation.

He echoes Paulien in stating that Christians must get to know secular people, providing opportunities for them to meet credible Christians. Friendships are bridges; social networks and contacts are avenues that will touch the secular person. We need new "ports of entry" for people to come in contact with us. Secular people need to be needed. They can be reached by helping others.

Fowler's discussion of a "blurred and self-defeating negative evangelistic approach" reverberates with Sahlin's "prophetic era" of Adventist evangelism. He agrees with Sahlin that we need to adjust our evangelistic methods. The condemnatory critiquing of the prevailing "apostate" churches is offensive to many secular minds today. The program of subjects presented in such a short time does not 
give the recipient enough time to assimilate the material. We must accept people, bring them into our fellowship, become their friends, and then they will want to know our doctrines, be baptized, and become an official part of the church family. Fowler also sees the wisdom in small groups and one-on-one friendships.

We need to stop "converting" people to Adventism through rational, propositional truths alone. The gospel must be primarily marketed as a relationship with Jesus.

Newman speaks that one point stands out above all others in reaching secular people: We must spend time with them.

Bruinsma echoes Paulien's sentiments that we must contextualize the gospel and couch it in a loving relationship.

Moyer's focus is on urban need, the pressing necessity to evangelize the teaming megacities of the planet. Many of the most secularized people live in vast urban areas. We need to alter our rural-only evangelistic approach to one that encompasses a clear focus on urban need. We need to discover what kind of evangelistic methods can best communicate the gospel to these people.

\section{Chapter 4}

Hunter writes that during the first three centuries, Christianity faced an empire with no knowledge of the gospel 
and hostile populations that required friendship before evangelism. Since there were several entrenched religions, Christians had to first convince people of Christianity's truth or at least its plausibility. Only after these steps were followed could Christians invite people to join the Church.

After Christianity was established, Christians could skip the first three steps. However, with secularism entrenched in our culture and the Church's defensive reaction to it, many people have become alienated from the Church and have left it for greener pastures. The Church must now plow, seed, and water the fields before a harvest can be expected.

Secularization has not erased all religious consciousness from people's minds. Secular people are not immoral, but they receive their marching orders from peers, parents, or their pop culture instead of the Church or its Scriptures. Most secular people are naive and will fall for anything .

Hunter gives several themes and strategies for reaching secular people. Many of these themes are echoed in other authors' material. There is a broad consensus among writers seeking to reach the secular mind that secular people want a quality of life now. Their focus is on this earth. They are more receptive when we start our relationship with them 
by addressing a need.

We must start at the beginning, not the middle. Many secular people are ignorant of Christianity.

They want to participate in the learning process; they do not like passively receiving information through a monologue.

They do not like authoritarian preaching. The secular populations enjoy skits or drama that speaks to their everyday life. The communicator needs to use dialogue, along with a great amount of just listening.

Christians need to identify when secular people experience receptive seasons in their lives, when they are dissatisfied with their lives.

As Paulien stated earlier, we must contextualize the gospel. We need to increase the pathways, the "unites" of the church. New units, new classes, new groups, new choirs, and new congregations will disciple more secular people than will old units. Secular people want to get in on the start of something.

We must meet secular people on their own turf first. We must personalize our message; Christianity must affect and add meaning to us personally. There must be no pressure for a decision. We need to use storytelling rather than biblical instruction. The truth is not negotiable, but the outer form through which we express it is negotiable. 
Schuller's formula says that the unchurched people's needs will determine our programs, their hang-ups will determine our strategy, their culture will determine our style, and their population will determine our growth goals. Hybels declares that the typical traditional church is no place for the unchurched. Our music, our dress, our language, the subjects we discuss, the poor quality of what we do--all lead the typical unchurched person to say, "This is definitely not for me."

He suggests a seven-step process that turns a secular person into a fully devoted follower of Christ. We start with building an authentic relationship with them, then share our personal journey, and bring them to a service specifically designed for them. After a time, they will transition to a service for believers. Then they join a small group where they will discover, develop, and deploy their spiritual gift. Finally, they will steward their resources in a God-honoring way.

Strobel posits that evangelism is a process, not a sudden event. Skeptical, secular people like to hear the evidence for and reasoning behind Christianity. Secular Harry can reject organized religion without rejecting God. Even though he is morally adrift, he wants an anchor. Harry has many questions, but he does not think Christians want to hear them. He is more concerned with the 
question "Does Christianity work?" than with "Is Christianity true?" He wants to experience Christianity, not just know it.

Harry wants to be someone's friend, not their project. He is open to places where they will meet his needs, as opposed to denominations where a particular truth will be presented.

Anderson echoes several authors' statement that Christian communicators must understand both the people and the culture in which they live. Their message must be relevant.

The rise of consumerism is the greatest factor in denominational decline. People shop around for a church that meets their needs. Anderson echoes Hunter's suggestion that we must change the starting point of evangelism. There are millions of peoples today who have never cracked a Bible and have never been to church.

We must not use yesterday's answers for today's questions. We must fulfill our mission, not perpetuate our traditions.

In balance, absolute truths supercede private preferences. They must not allow secular values to take root in the church. Evangelicals are polarizing into two camps. In one camp the monastics stick to truth and tradition. In the other camp are clustered post-Christian 
secularists who are sociologically relevant but are no longer truly Christian. There is a fine line between clever marketing and compromised spirituality.

Organizations must not be resistant to qualitative change. Institutions must not keep wistfully looking to the past. Churches must try to be better by doing different things, not by trying to do the same things better. The essential exercise is to first understand the culture and then to translate the meaning of the message into that culture.

Easum articulates that many congregations are becoming irrelevant to a hurting unchurched world and are unable to offer new wine to the new generation. Churches must stop looking to the past and start applying new culturally relevant ways to apply the good news to a new emerging world. The fastest way to fail is to continually improve on yesterday's successes.

Small groups perform most of the traditional roles played by the pastor, such as counseling, evangelism, and new member assimilation.

Music is the vehicle through which most unchurched people experience worship. The type of music that reaches people comes out of their culture. Only 4 percent of the records sold in the U.S. are classical. Hymnals are often discarded or supplemented with praise choruses that reflect 
contemporary tastes in music.

Changing music habits of declining or stagnant congregations is proving to be a major source of conflict. Two styles of worship are needed in churches that have reached their plateaus or are declining. Entertainment is vital to contemporary evangelism. Music and drama are a major form of reaching the unchurched. Effective preaching makes a passionate appeal to the emotions.

Weekday ministries overshadow the importance of Sunday. Weekday Bible studies and retreats are reducing the importance of Sunday schools. People today expect a sevenday-a-week community of faith.

The critical difference between healthy and unhealthy congregations is that healthy ones do the common, mundane, boring tasks of ministry uncommonly well. They have a passion for excellence.

Easum believes that we must study sociology more than theology. I believe they should be studied with equal intensity and vigor.

Established churches have a problem with control. The old-timers want to control everything, keeping to the traditions of yesteryear. Worship services contrived in the fifties do not attract the unchurched. 


\section{Conclusions}

One last question needs to be asked-"So what?". What difference will this research make in my ministry? What difference could this seminar make in the ministry of the Hickory Seventh-day Adventist church member?

Secularism has impacted Seventh-day Adventists. I was unaware of its impact on me. I thought Hunter's "Utter Secularity" was the only definition of a secular person. Yet his categories "Mere" and "Controlled Secularity" to some degree describe too many Adventists, including me. We are too preoccupied with this world, our daily routines. It is very easy to retain the shell of Christianity, e.g. go to church, attend our schools, join our clubs, and have little commitment to Jesus. We can place too much emphasis on traditional American values.

We can get caught up in the religious system and not even ask questions about its relevance in our lives. Adventists tend to be logical, cerebral thinkers. We have paraded our logical answers to everything as one of our greatest strengths. Perhaps all our rational thinking is. one of our greatest weaknesses, when it doesn't naturally flow from a vibrant personal relationship with Jesus. We think logical propositional truths are the answer--a long systematic string of doctrine. This thinking also typifies modernity, secularism. 
Satan is a systematic, logical theologian. Yet he doesn't have a personal relationship with Jesus. That, in the end, is what brought him down.

I recognize that today, post-modernism has followed on the heels of secularism. For this reason, I plan to include a section on post-modernism in my seminar. Many people today correctly see the need to experience Jesus. Mere $\operatorname{logic}$ is not the answer.

Perhaps Paul said it best when he wrote:

And when I came to you, brethren, I did not come with superiority of speech or of wisdom, proclaiming to you the testimony of God. 12\} For I determined to know nothing among you except Jesus Christ, and Him crucified. (1 Cor 2:1-2) 
APPENDIX

A POWERPOINT PRESENTATION ENTITLED

"THE REST OF MANKIND: REACHING THE

$21^{\text {ST }}$ CENTURY SECULAR MIND"

by

J. Kenneth Ford 


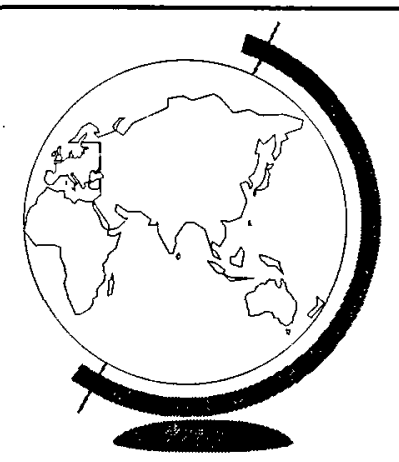

The Rest of Mankind

Reaching the $21^{\text {st }}$ century secular mind

\section{Our Marching Orders...}

$\rightarrow$ Go

$\varpi$ Everywhere

Invite everybody
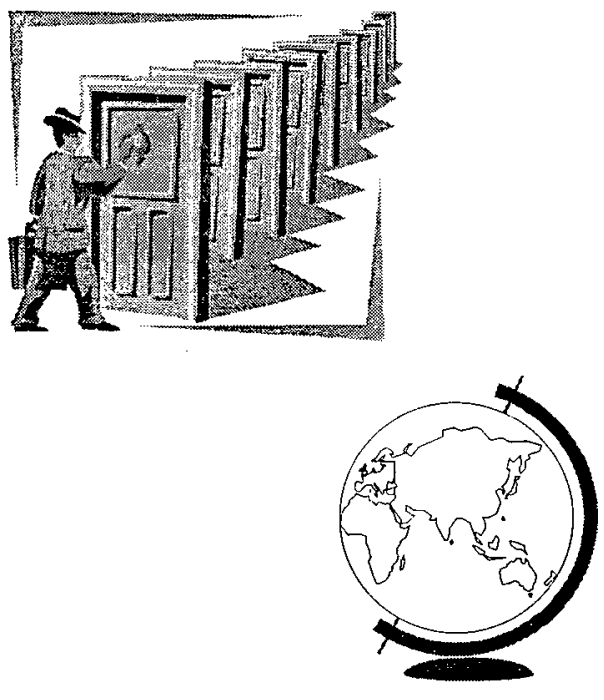
Acts 15:15-18 (NASB) ${ }^{15}$ "With this the words of the Prophets agree, just as it is written, ${ }^{166}$ After these things I will return, And I will rebuild the tabernacle of David which has fallen, And I will rebuild its ruins, And I will restore it, ${ }^{17}$ So that the rest of mankind may seek the Lord, And all the Gentiles who are called by my name,' ${ }^{18}$ Says the Lord, who makes these things known from long ago.
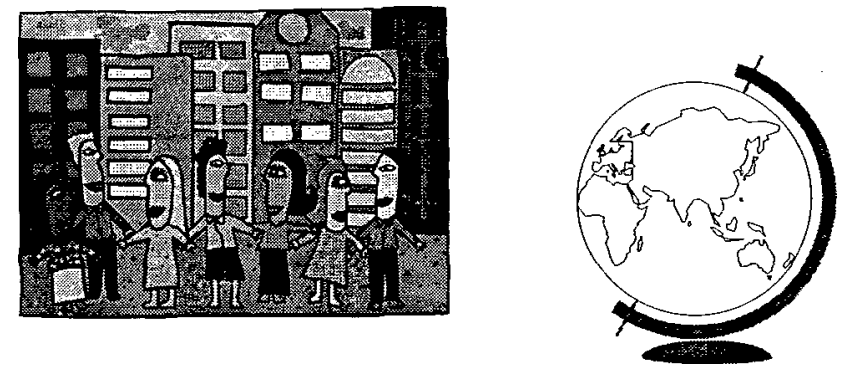

Isa. 56:7 (NASB) ${ }^{7}$ Even those I will bring to My holy mountain and make them joyful in My house of prayer. Their burnt offerings and their sacrifices will be acceptable on My altar; for My house will be called a house of prayer for all the peoples."
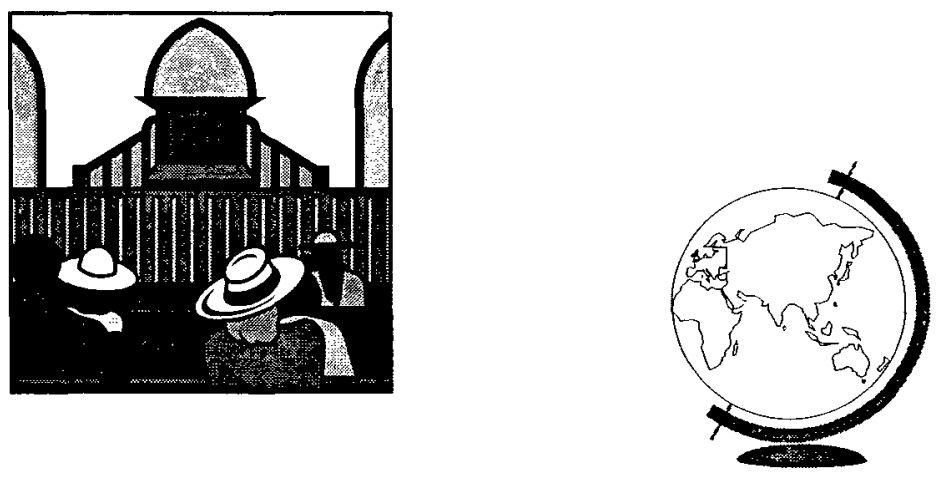
Matt. 24:14 (NASB) ${ }^{14 "}$ This gospel of the kingdom shall be preached in the whole world as a testimony to all the nations, and then the end will come.
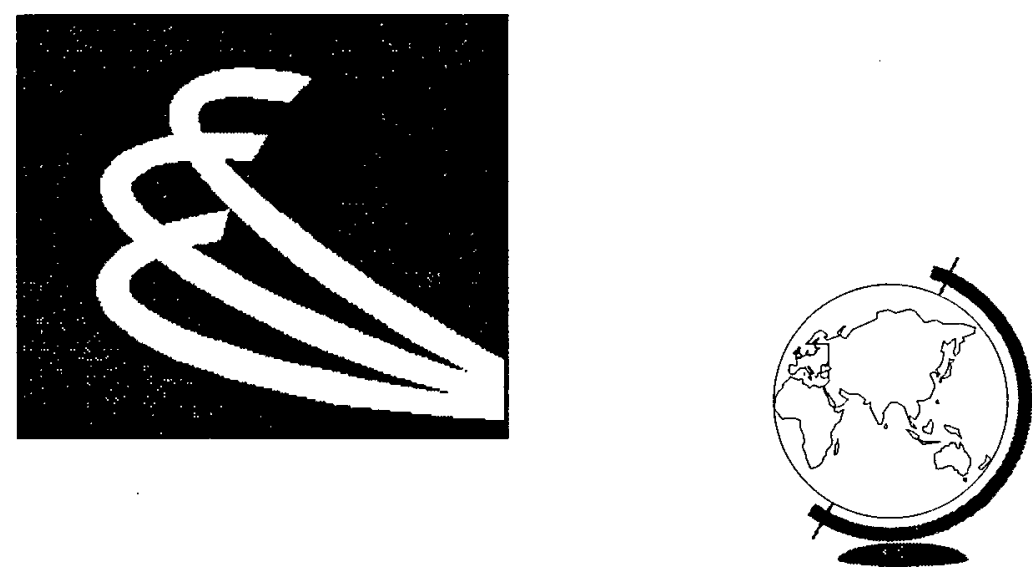

Matt. 28:19 (NASB) ${ }^{19}$ "Go therefore and make disciples of all the nations, baptizing them in the name of the Father and the Son and the Holy Spirit,
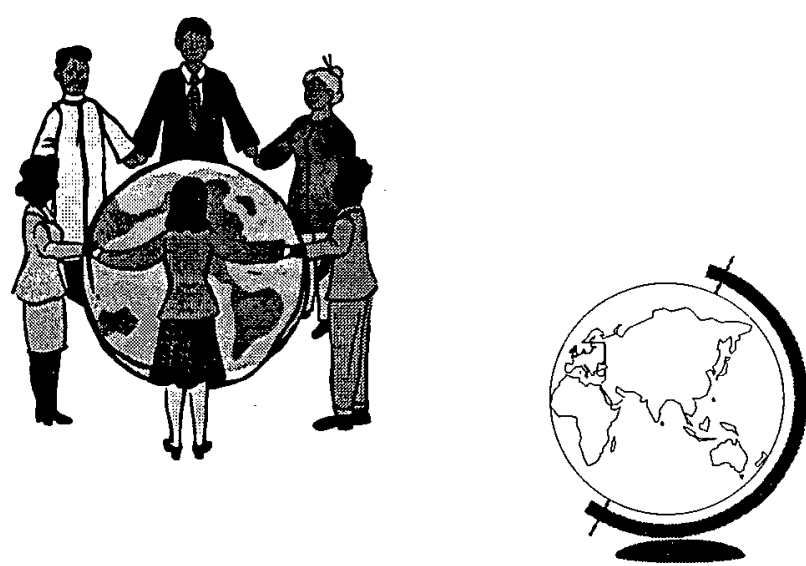
Mark 16:15 (NASB) ${ }^{15}$ And He said to them, "Go into all the world and preach the gospel to all creation.
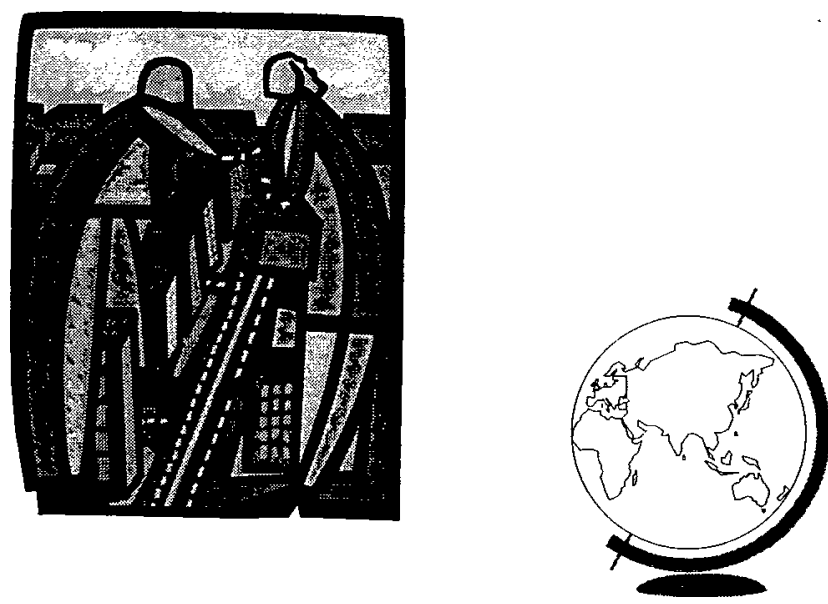

Acts 1:8 (NASB) ${ }^{8}$ but you will receive power when the Holy Spirit has come upon you; and you shall be My witnesses both in Jerusalem, and in all Judea and Samaria, and even to the remotest part of the earth."
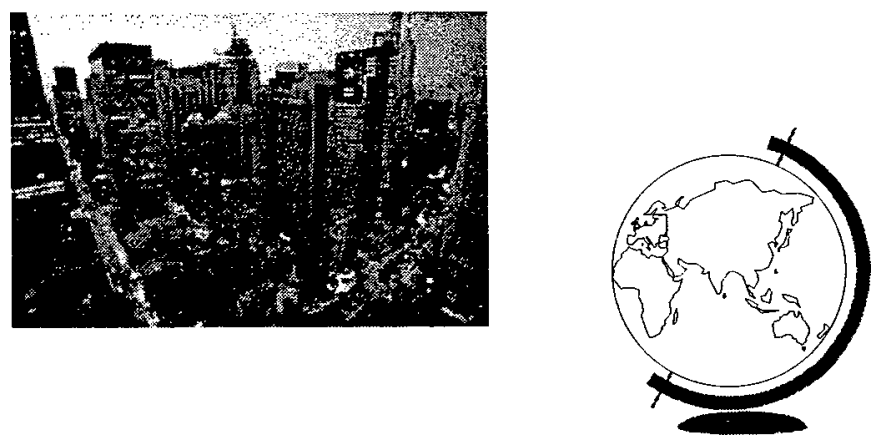
Acts 2:47 (NASB) ${ }^{47}$ praising God and having favor with all the people. And the Lord was adding to their number day by day those who were being saved.
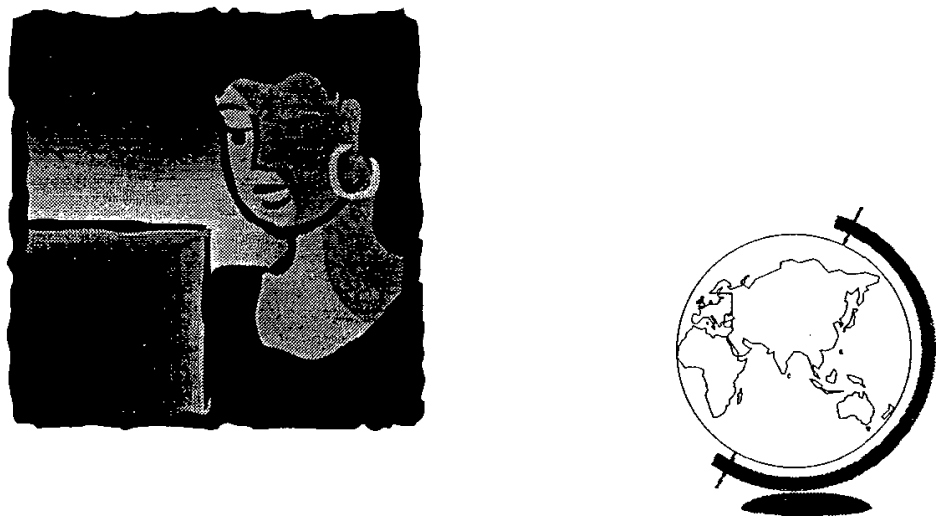

John 10:16 (NASB) ${ }^{16 " I ~ h a v e ~ o t h e r ~ s h e e p, ~ w h i c h ~ a r e ~}$ not of this fold; I must bring them also, and they will hear My voice; and they will become one flock with one shepherd.
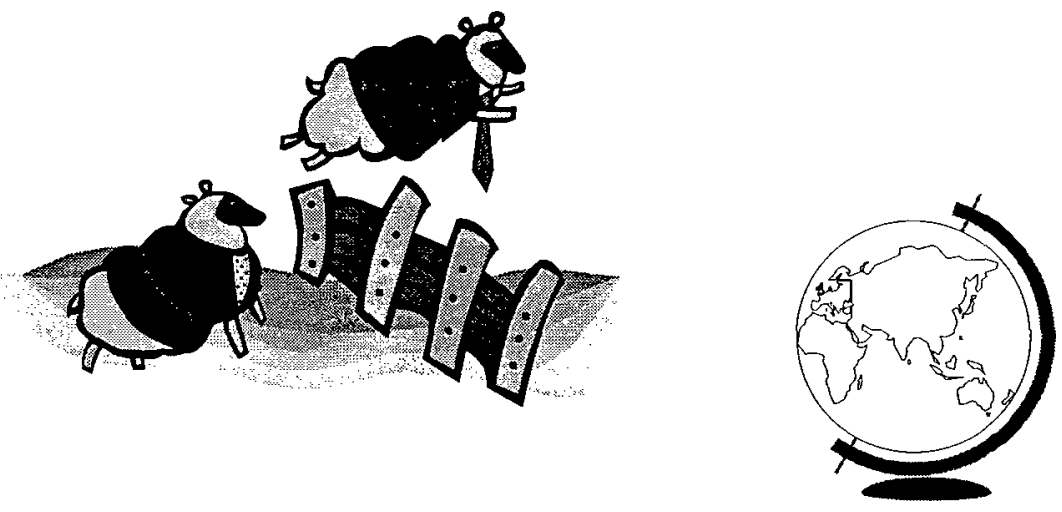


\section{Recap and moving on...}

- Jesus is avidly concerned about the rest of mankind too.

$\leftarrow$ There are Gentiles who are called by His Name.

$\sigma$ God's house is for all people-groups.

The gospel must go out to all the world, all nations, all creation.

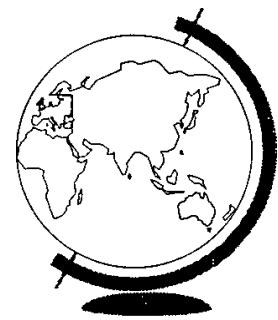

\section{Recap and moving on...}

- Jesus' followers must witness in even the remotest parts of the earth. "Remote" includes receptivity, not just geography.

$\varpi$ Jesus' followers are to have favor with all people-groups.

$\sigma$ Jesus has other sheep, not of the original fold, who will hear His voice. They will become part of the one flock. 


\section{Recap and moving on...}

There are Gentiles that will listen to God's salvation.

Persons from all people-groups are fellow-heirs and fellow members of the body of Christ.

$\sigma$ In summary, we are to go to all people-groups everywhere.

Now we will turn our attention to secular people, a group that is included in the gospel commission.

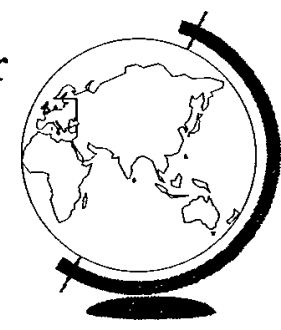

\section{Defining secularism...}

Secularism has been defined as religious skepticism or indifference.

$\sigma$ Secular people tend to be indifferent and unresponsive to religion. They prefer the advances of science and technology. They depend on themselves, not God. God may exist, but they do not believe they need Him.

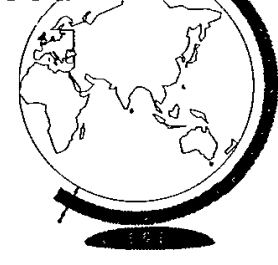


Mark Finley, currently the speaker/director for It Is Written, portrays four basic types of secularists:

\section{Finley's Four Types of Secularists}

1. The "secular materialists" chief interests are economics, money, and possessions.

2. The "religious dropouts" were brought up in a religious home, but are turned off with organized religion.

3. The "hard hats" are the tough all-Americans who work from sunup to sundown. They do not want to be bothered with religion, they are too busy working.

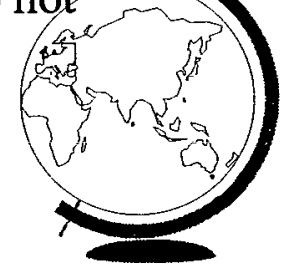


4. And finally, the "secular philosophers" are introspective and thoughtful. They reject Christianity as a viable option. They are turned off by those who quote Scripture as authoritative. They prefer a naturalistic world view.

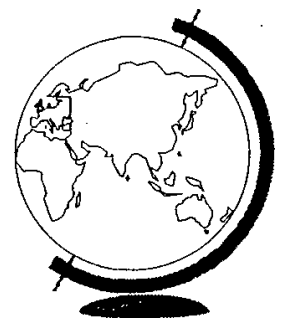

George Hunter is currently Dean at the E.

Stanley Jones School of Evangelism and World Mission at Asbury Theological Seminary. He posits ten characteristics of secular people:

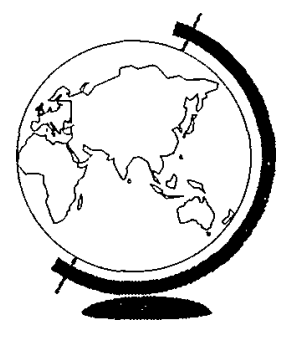




\section{Hunter's ten characteristics of secular people}

1. Secular people are essentially ignorant of basic Christianity.

2. Secular people are seeking life before death. The don't focus on the heavenly reward, they want a better life now.

3. Secular people are conscious of doubt more than guilt. Doubt is now the number-one factor in the secular audience.

\section{Hunter's ten characteristics of secular people cont.}

4. Secular people have a negative image of the Church. They doubt the intelligence, relevance, and credibility of the Church and its advocates. They still place more confidence in science and common sense than in religion. The doubts regarding the church's relevance began when the Church reacted defensively to the events of secularization.

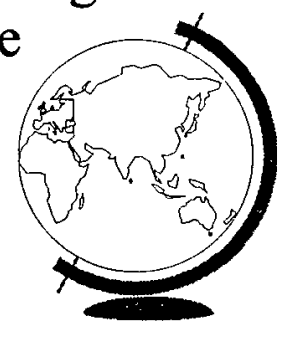




\section{Hunter's ten characteristics of secular people cont.}

5. Secular people have multiple alienations. These would include alienation from nature (sport killing, strip mining, endangered species, ecological crisis), from neighbors (high-rise apartments etc.), from political and economic systems upon which their lives depend, as evidenced from the breakdown of lifetime job security. Others would include alienation from their vocations, as evidenced by their expressed lack of meaning in their life work and their obsession with leisure pursuits.

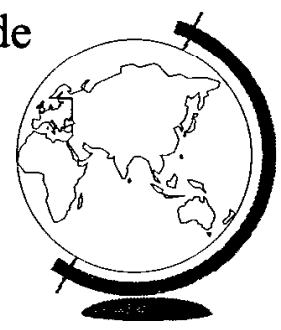

\section{Hunter's ten characteristics of secular people cont.}

6. Secular people are untrusting. Schuller believes that it is more useful to relate to a nonchristian as a nontrusting person, i.e. fearful and suspicious, than to relate to him or her as an evil or depraved or shameful soul.

7. Secular people have low self-esteem.

8. Secular people experience forces in history as "out of control." They face the future with great anxiety. 


\section{Hunter's ten characteristics of secular people cont.}

8. Secular people experience forces in history as "out of control." They face the future with great anxiety.

9. Secular people experience forces in their personal lives as out of control, such as addictions and substance abuse.

10. Secular people cannot find "the door," to God.
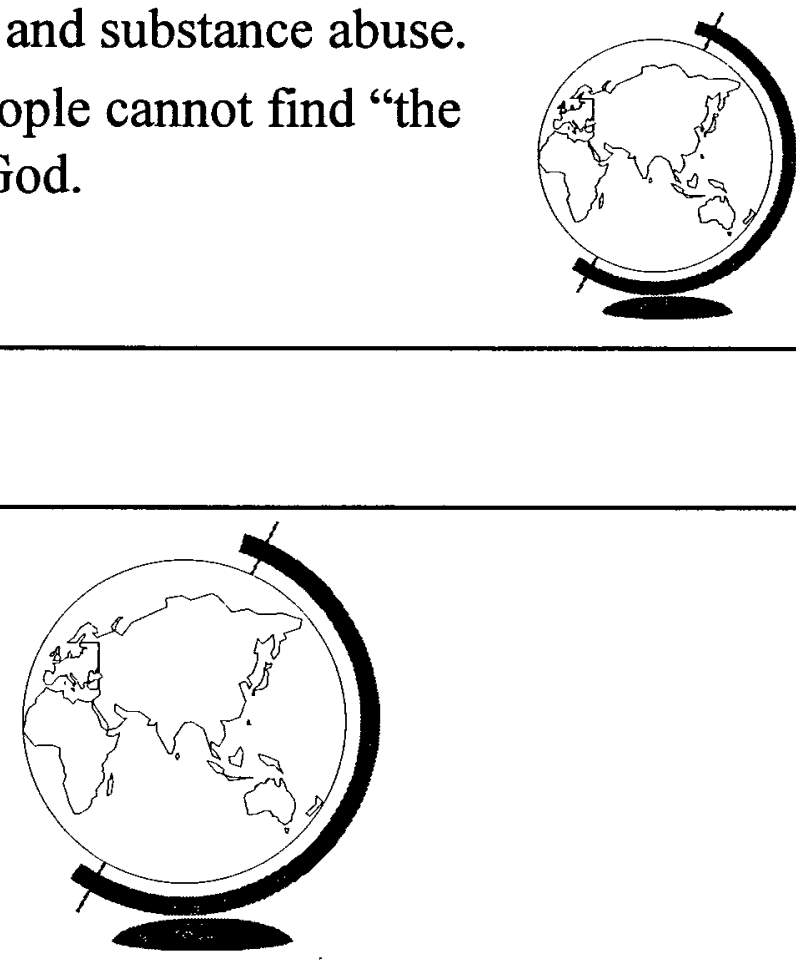

The Rest of Mankind

Reaching the $21^{\text {st }}$ century secular mind Seminar Module Two 


\section{Origin \& Development of Secularism}

Introductory Statement (based on pgs. 12-15 of dissertation).
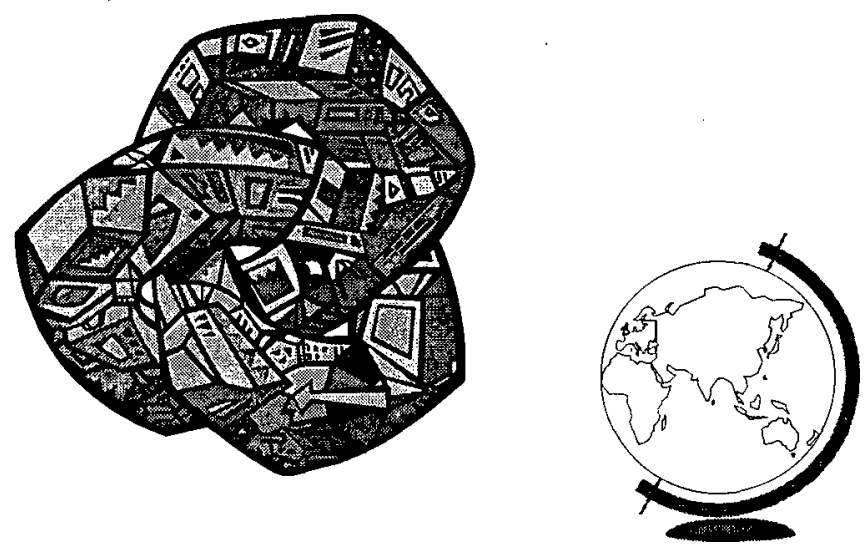

\section{Gottfried Oosterwal}

$\leftarrow$ Havey Cox's three stages in the process of secularization:

- Tribal stage.

- Town stage.

- Technopolis stage.

- Contingency.

- Autonomy.

- Temporality.

- Relativity.
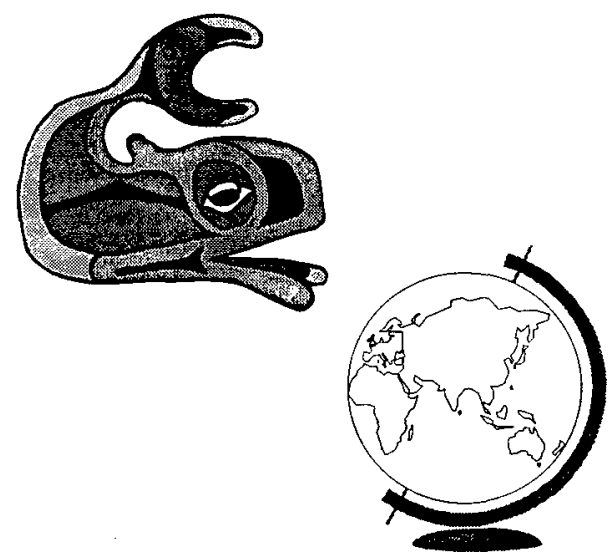


\section{Gottfried Oosterwal}

Six characteristics of the process of secularization.

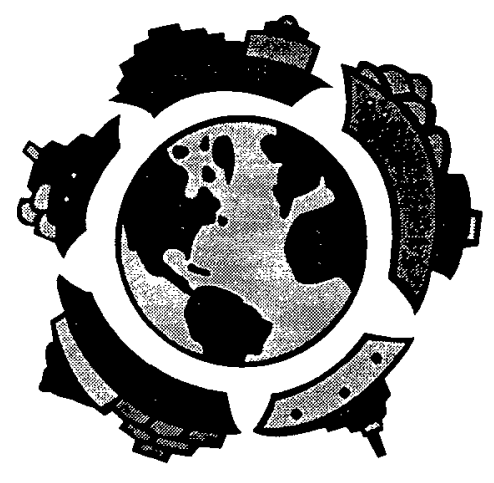

\section{Jon Paulien}

Three major influences driving secularism.

- Science.

- Pluralism.

- Privatization.
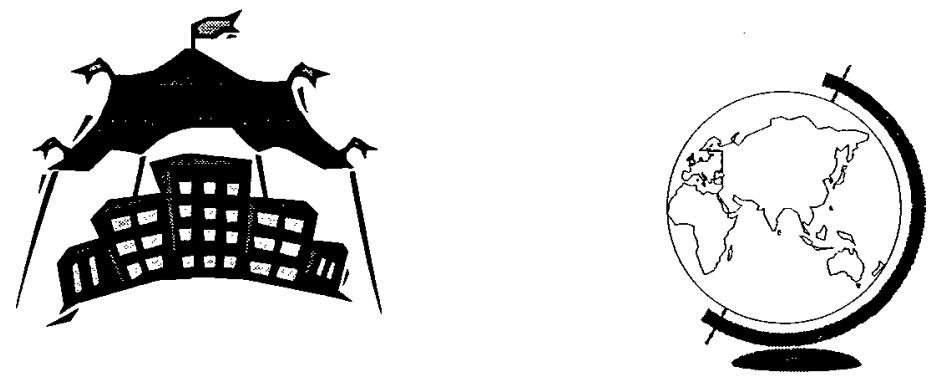


\section{Jon Paulien}

- Our response to secularism.

- Escape into the present.

- Escape into a group that separates from the world.

- Plunge into the world as it is.

Break-out. Discuss the above for 15 minutes.

\section{George Hunter III}

$\infty$ Describe "How the West Was Lost."

Six pivotal events that caused the ebbing of Christendom and the secularization of the West."
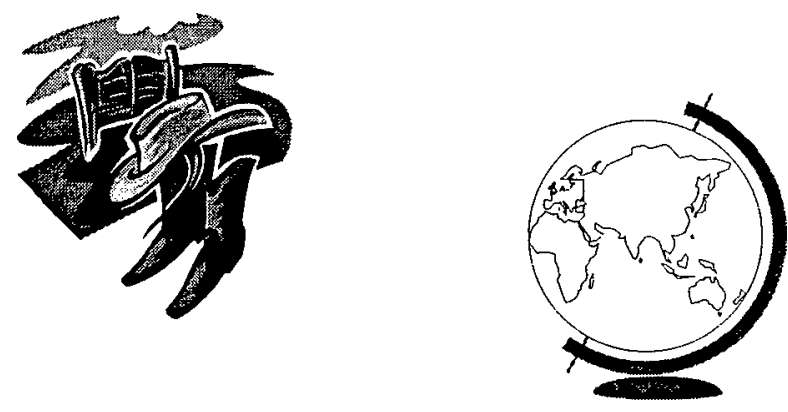


\section{Timothy Phillips \& Dennis Okholm}

$\sigma$ Describe their concept of the secularization of the church.
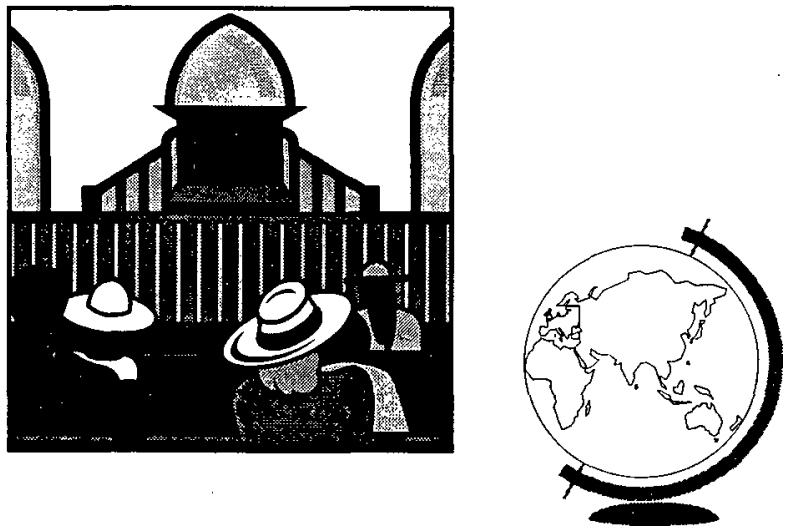

\section{William Easum}

Describe the twelve assumptions that form a filter for his book.
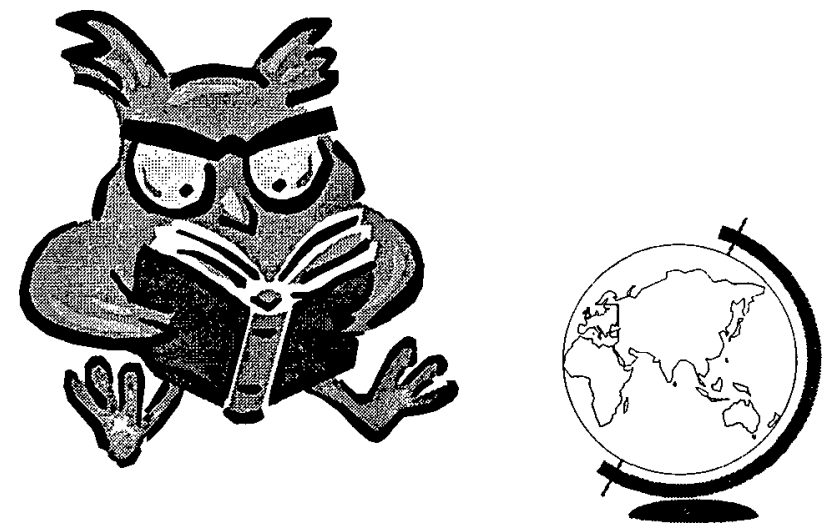


\section{Secularism in the SDA Church}

$\sigma$ Jon Pauline's six ways in which SDA's become secular.
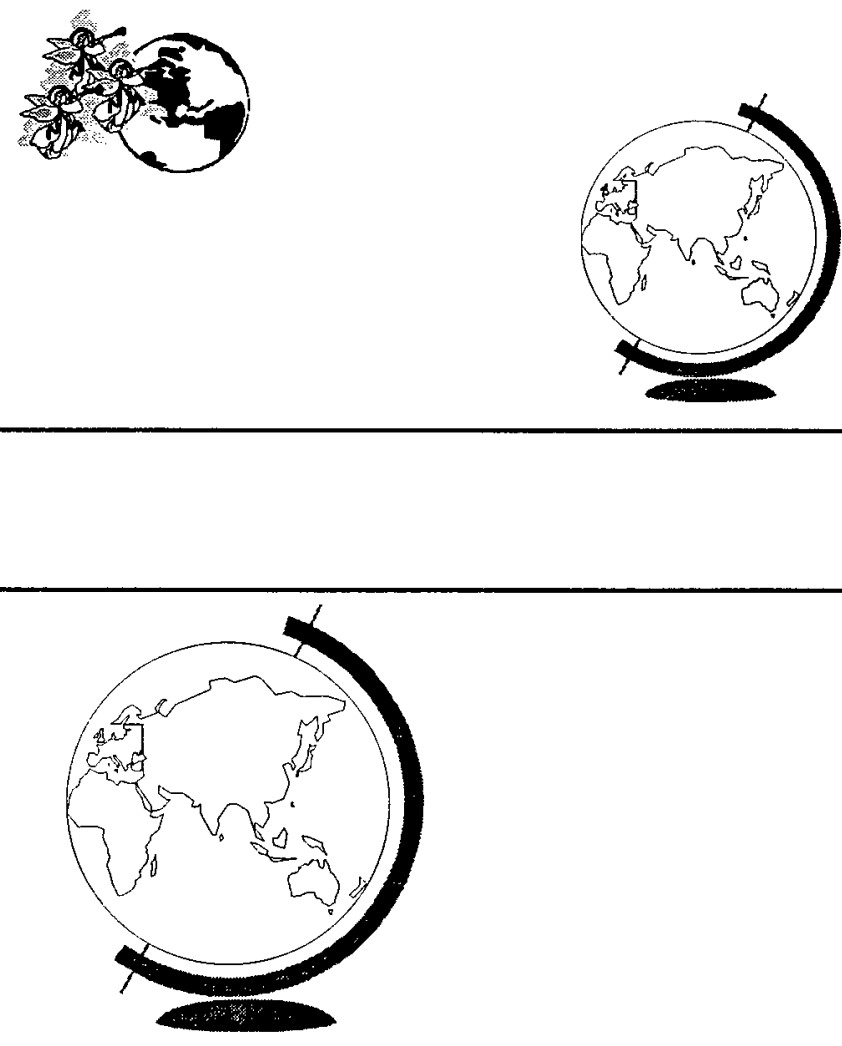

The Rest of Mankind

Reaching the $21^{\text {st }}$ century secular mind Seminar Module Three 


\section{Secularism in the SDA Church}

$\checkmark$ Jon Pauline's six ways in which SDA's become secular.
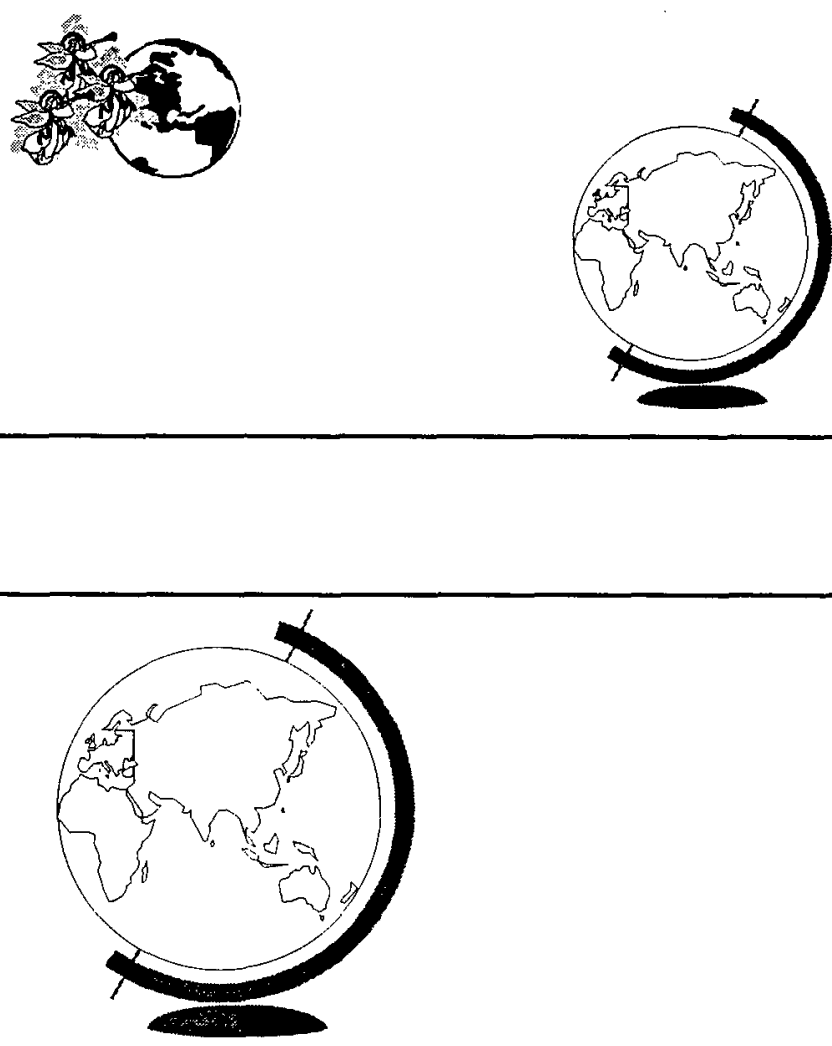

The Rest of Mankind

Reaching the $21^{\text {st }}$ century secular mind Seminar Module Three 


\section{Recap and moving on...}

There are Gentiles that will listen to God's salvation.

$\leftarrow$ Persons from all people-groups are fellow-heirs and fellow members of the body of Christ.

- In summary, we are to go to all people-groups everywhere. Now we will look at various methods Scripture introduces to reach all peoplegroups.

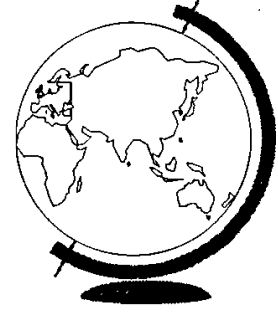

\section{Methods of reaching others introduced in Scripture...}

Our end primary goal is to lead others to a relationship with Jesus. Jesus said, "Follow me."

There are many approaches being tried today to reach the secular mind. Highly creative technology, worship service design and music, brilliant preaching, magnetic personalities and small groups, are just a few examples. These are all useful, but not primary.

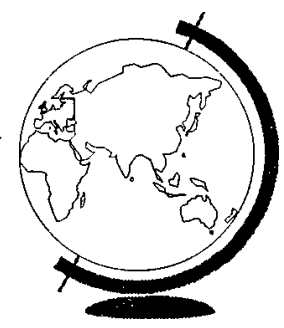




\section{Recap and moving on...}

There are Gentiles that will listen to God's salvation.

- Persons from all people-groups are fellow-heirs and fellow members of the body of Christ.

- In summary, we are to go to all people-groups everywhere. Now we will look at various methods Scripture introduces to reach all peoplegroups.

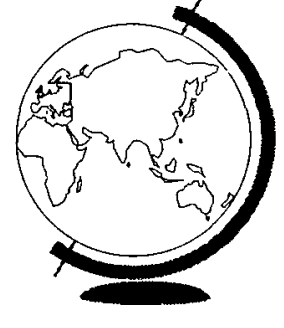

\section{Methods of reaching others introduced in Scripture...}

$\rightarrow$ Our end primary goal is to lead others to a relationship with Jesus. Jesus said, "Follow me."

There are many approaches being tried today to reach the secular mind. Highly creative technology, worship service design and music, brilliant preaching, magnetic personalities and small groups, are just a few examples. These are all useful, but not primary.

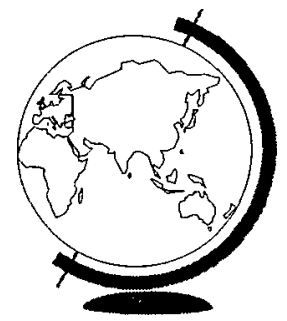




\section{Methods of reaching others introduced in Scripture...}

- Address practical human needs.

Jesus fed people by the thousands, He didn't ignore the current needs of his audience. He helped people with their addictions. If Jesus lived today, He would help people get a pair of glasses, find some crutches, help AIDS patients, work with the deaf and dumb, bring relief to the poor, instigate a "Meals on Wheels."

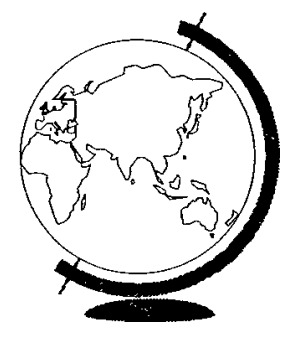

\section{Methods of reaching others introduced in Scripture...}

Address practical human needs.

The disciples were empowered to heal every kind of disease and sickness, emotional and physical. They didn't just go around preaching an abstract otherworldly gospel that ignored the present. They kept at it "every day," a seven-day-a-week church program. 


\section{Methods of reaching others introduced in Scripture...}

$\rightarrow$ Address practical human needs.

And daily God added to their numbers. Members were not just indoctrinated and added to the church roster during the Sabbath church service. There "was not a needy person among" the New Testament church members. That is practical Christianity!

\section{Methods of reaching others introduced in Scripture...}

$\rightarrow$ Jesus used the parable often.

Jesus' usual method of teaching/preaching was the parable. Our Creator knew that people liked stories to which they could relate. Parables helped people to visualize abstract concepts, they "pulled people into" the insight being discussed. Christ's parables portrayed everyday life in graphic language. Secular minded people are focused on this life.

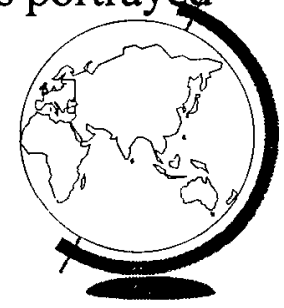




\section{Methods of reaching others introduced in Scripture...}

Jesus compared spreading the gospel to fishing. A hook suggests spreading the gospel one-on-one. The net represents gathering people in groups, such as through evangelistic meetings. Various ideas introduced by the symbolism of the hook would include:
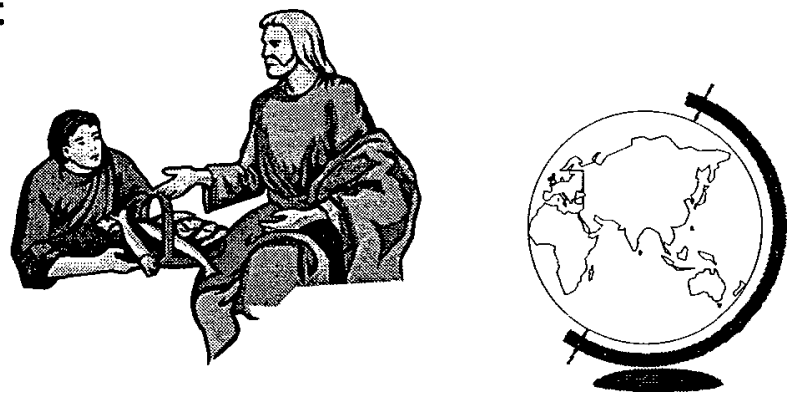

1. Which hook to use

2. Where to throw the hook

3. The best way to throw the hook

4. What kind of fish are you looking for

5. How to care for the fish once caught

6. What equipment is needed

7. What type of water do the fish live in

8. What is the geographical area (type of society)

9. Are you fishing day or night

10. Is the tide in or out

11. What are the customs of the fish

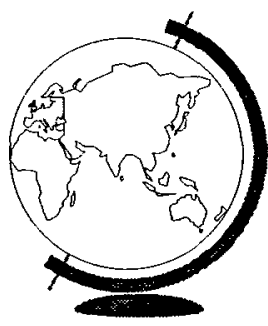




\section{Methods of reaching others introduced in Scripture...}

We must be open to new ideas and methods of reaching others.

$\varpi$ Read Luke 5:36-Luke 5:39

\section{Methods of reaching others introduced in Scripture...}

We must be open to new ideas and methods of reaching others.

The parable of the cloth and wineskins suggests that we cannot stick with tradition, as such, and reach the secular mind. Secular minded people want change, they want practical religion, they want a religion that keeps up with the times, they want a religion that meets specific needs.

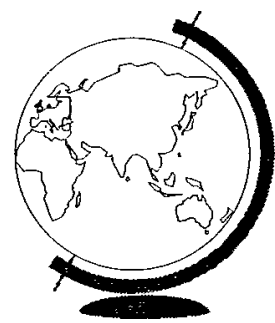




\section{Methods of reaching others introduced in Scripture...}

$\varpi$ We must be open to new ideas and methods of reaching others.

Just saying "it's inspired" isn't enough for the secular mind. Any number of inspired sayings from various holy people are all equally good, or bad.

\section{Methods of reaching others introduced in Scripture...}

We must be open to new ideas and methods of reaching others.

We tend to look at things through our own personal lenses, based on our environment, our traditions. We need to be open to brand new ways of looking at things. 


\section{Methods of reaching others introduced in Scripture...}

Lessons from the interview with the Samaritan woman (John 4).

- Break-out Small-Group Session. (Divide into groups of three or four). Handouts provided that list the following eleven points. Locate each characteristic in the passage. After thirty minutes come back together as one large group and discuss answers.
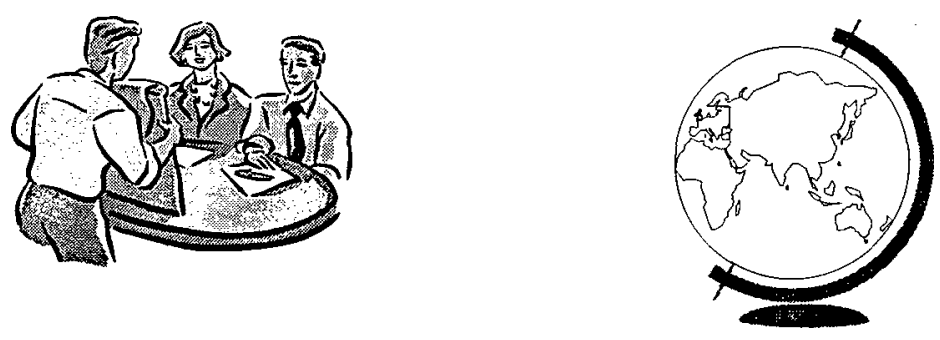

1. Christ awakened interest through secular conversation-water. He used His need for water to reach her.

2. He used ingenuity, initially asking for water, and then ending up offering better water.

3. He spoke with authority, stating that she would never thirst again.

4. He pointed to a higher life, of heavenly things.

5. He used euphemism by saying hard things in a palatable way.

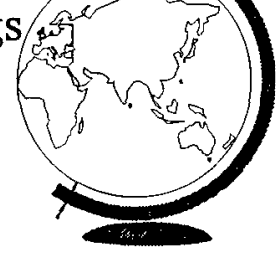


6. He chose the questions he wanted to answer and ignored the others

7. He avoided confrontational questions.

8. He struck for the open nerve that causes a person to expose their need(s).

9. He told the truth, even when it hurt.

10. He agreed with the person as much as possible.

11. He didn't allow the conversation to get off the subject.

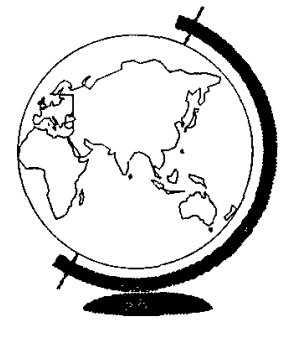

\section{Methods of reaching others introduced in Scripture...}

Jesus sent them out in pairs. Read Mark 6:7

They had debriefing sessions. Read 6:30

- They adapted their approach depending on whom they were working with at the time. Read 1 Cor 9:20-23

- They gave only as much information as recipient was able to bear. Read 1 Cor 9:20-23

They planted new churches.

Read Acts 22:17-21

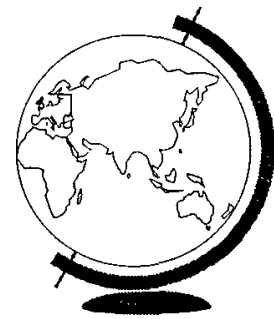




\section{Methods of reaching others introduced in Scripture...}

$\sigma$ They talked in the heart language of the listener. Read 1 Cor 14:19. Paul said it was better to speak a few words in a language that the listener understood, than thousands of words in a language that they didn't understand. He saw the importance of "talking their language" in presenting the gospel.

\section{Methods of reaching others introduced in Scripture...}

$\rightarrow$ They had a relational ministry, often inviting people over to their homes for social activities. Read John 1:37-39

$\sigma$ They went over to worldly people's homes for food and fellowship. Read Matt 9:10-13

They shared Jesus with their relatives. Read John 1:41

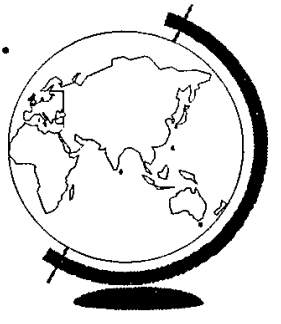




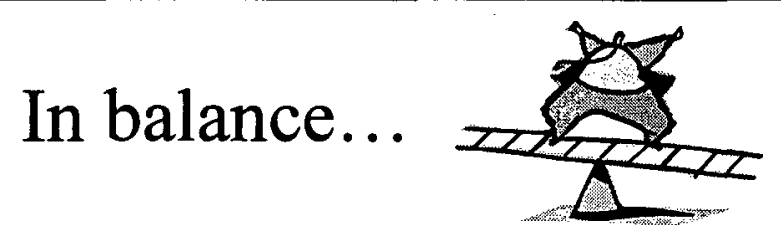

$\sigma$ The NT Christians guarded themselves from being stained by the world. Read Jas 1:27

They would not conform to the world. Read Rom $12: 2$

$\rightarrow$ They would not participate in worldly deeds of darkness. Read Eph 5:11

They would not marry unbelievers, hoping to win them to Christ later in the marriage. Read 2 Cor 6:14-17
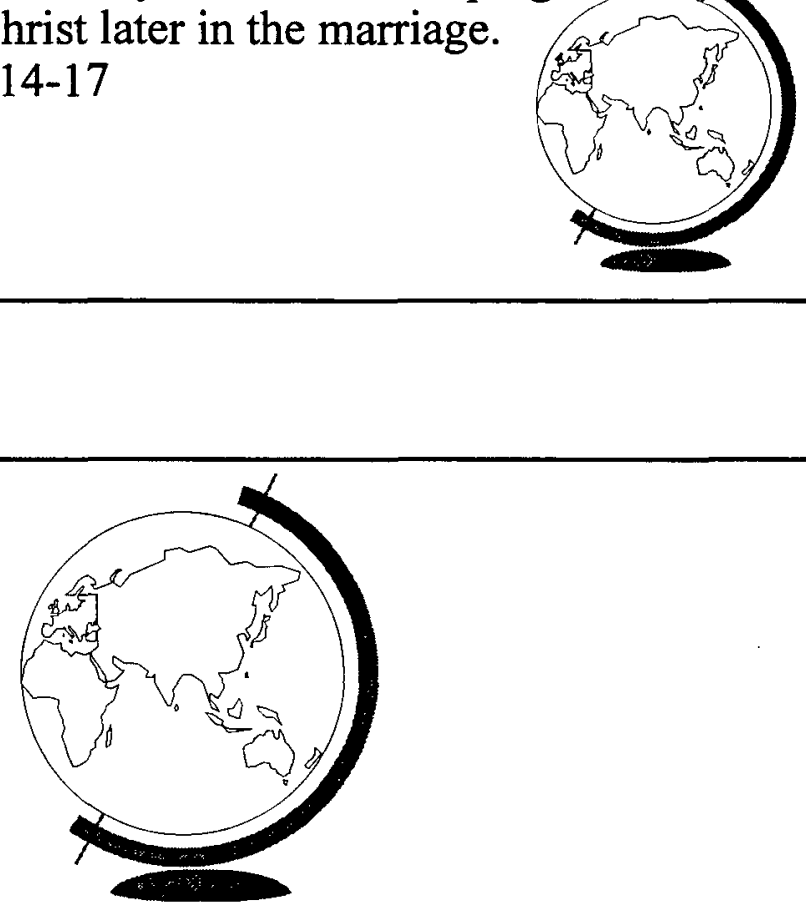

\section{The Rest of Mankind}

Reaching the $21^{\text {st }}$ century secular mind Seminar Module Four 


\section{Ellen White on Reaching the Secular Mind}

If you would approach the people acceptably, humble your hearts before God, and learn His ways. We shall gain much instruction for our work from a study of Christ's methods of labor and His manner of meeting the people. In the gospel story we have the record of how $\mathrm{He}$ worked for all classes, and of how as $\mathrm{He}$ labored in cities and towns, thousands were drawn to His side to hear His teaching. Ev 53

\section{Ellen White on Reaching the Secular Mind}

- We all must learn His methods of working. Ev 109

$\rightarrow$ His method alone will give true success in reaching the people. Ev 109

\% Christ didn't merely announce His blessings; $\mathrm{He}$ presented them "in the most alluring terms, the most attractive way, to excite a desire to possess them." $D A 826$

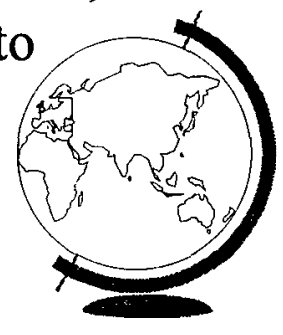




\section{Ellen White on Reaching the Secular Mind}

We must speak to humanity in the "language of humanity." DA 34

- It's like baiting with the right hook. EV 556

The "tameness" and "monotony" of our service for God "repels many." Ev 170
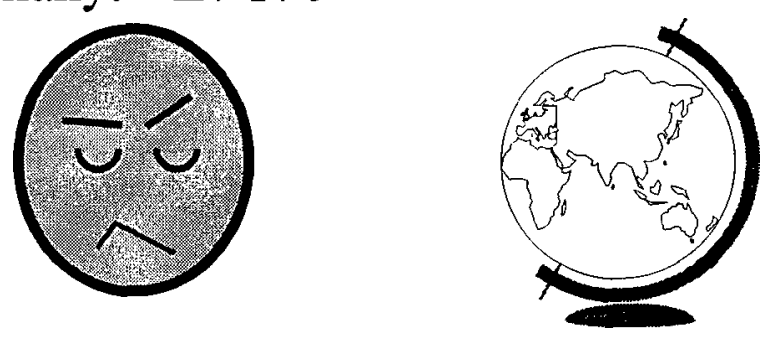

\section{Ellen White on \\ Reaching the Secular Mind}

$\rightarrow$ We need to be "taught as to the best way of approaching individuals and families." CS 227

$\rightarrow$ The way we present truth has a lot to do with whether it will be accepted or rejected. Ev 168
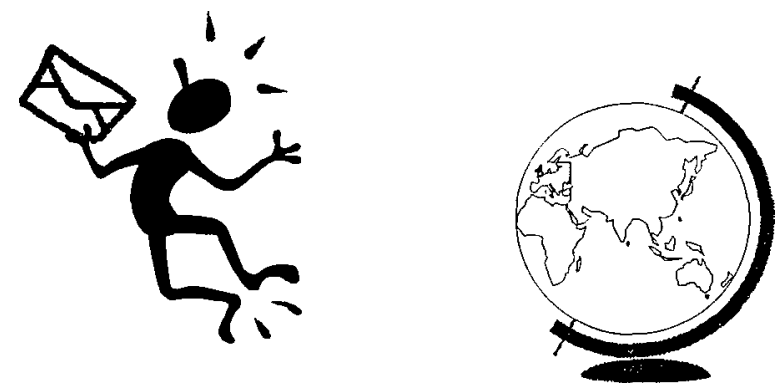


\section{Ellen White on Reaching the Secular Mind}

$\infty$ Jesus "surprised them with illustrations that won their attention," "taken from the things of daily life," He appealed to their "imagination." DA 254
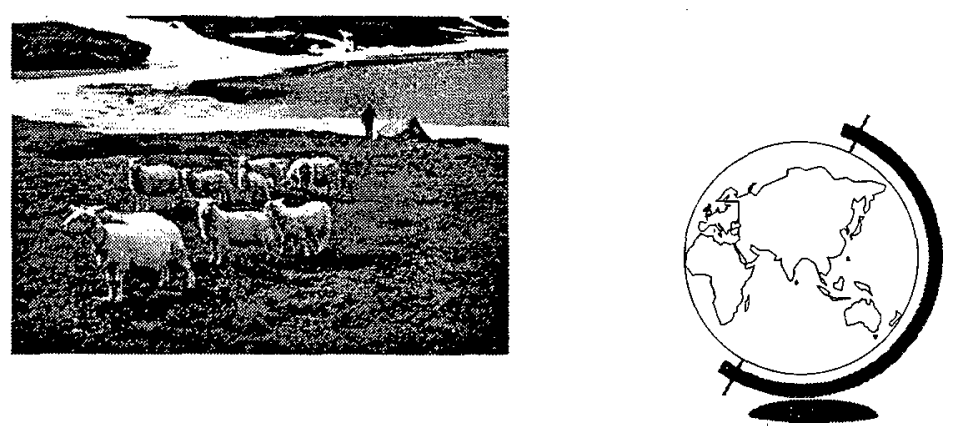

\section{Ellen White on \\ Reaching the Secular Mind}

Some "in the higher walks of life will grasp it as it is presented in figures and parables." Ev 557
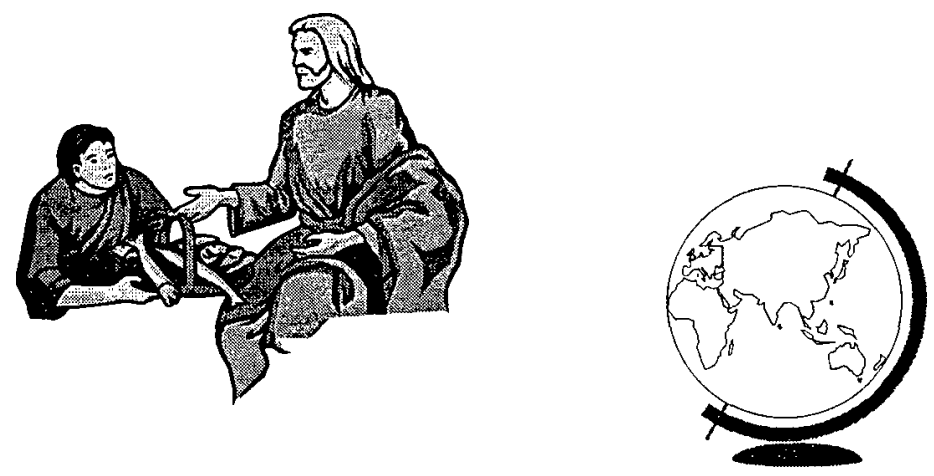


\section{Ellen White on Reaching the Secular Mind}

$\rightarrow$ Christ's servants should "accommodate themselves to the varied conditions of the people. ... Labor will have to be varied to meet the people where they are." $2 T 673$
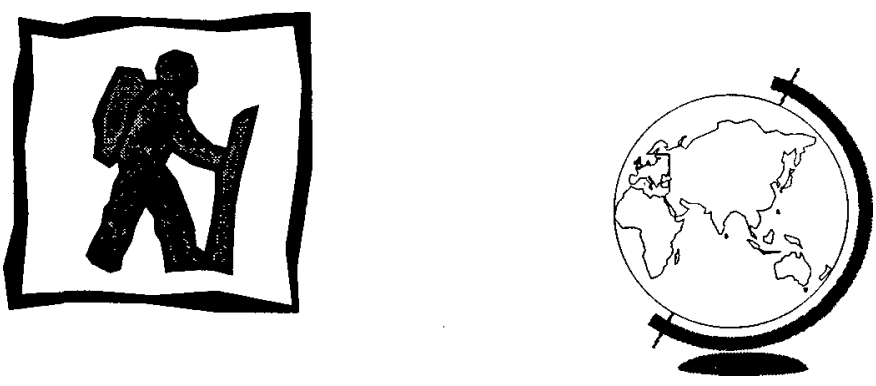

\section{Ellen White on}

Reaching the Secular Mind

$\rightarrow$ Our "truth must vary with the class of people" we are working with. Ev 106
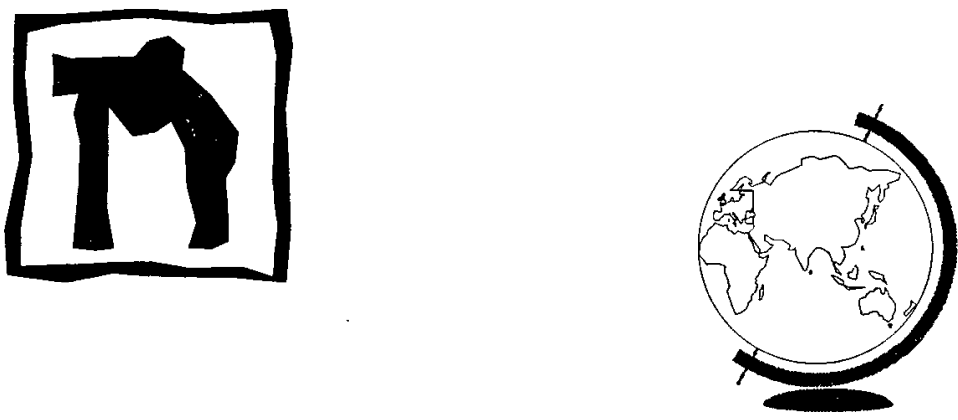


\section{Ellen White on Reaching the Secular Mind}

$\rightarrow$ The class of people we are trying to reach will determine what methods we use. Ev 106
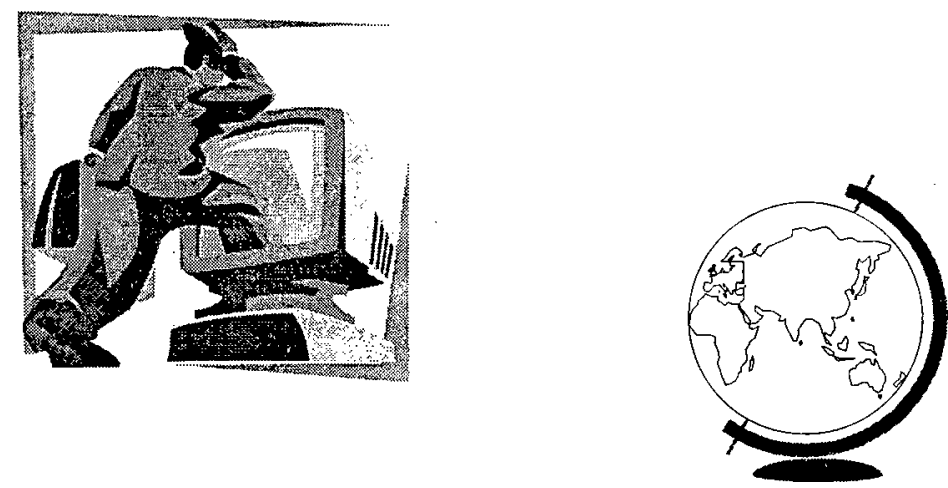

\section{Ellen White on}

Reaching the Secular Mind

New methods "must be introduced." The "lifeless way in which it [reaching people for Jesus] has been carried forward in the past" must cease. $E v 70$
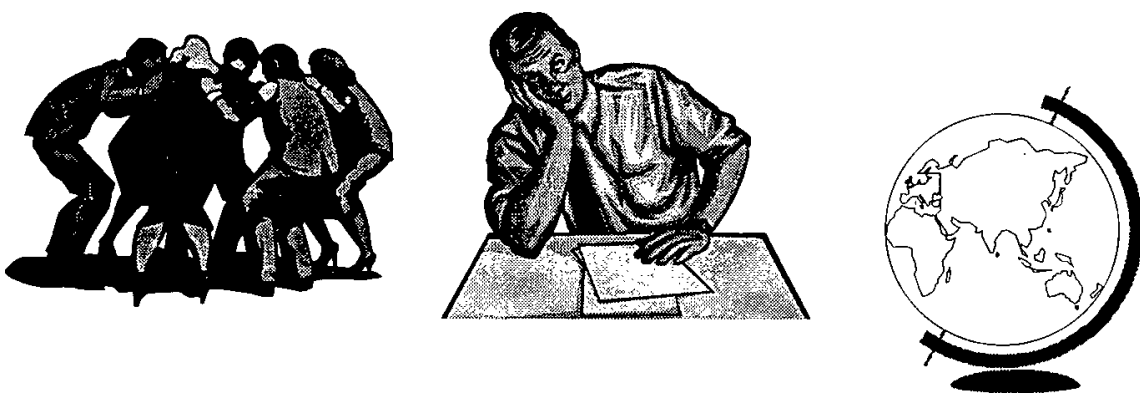


\section{Ellen White on \\ Reaching the Secular Mind}

$\rightarrow$ We must "arrest the attention," "do something out of the common course of things." Ev 122

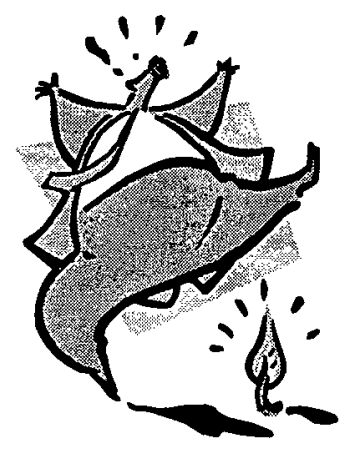

\section{Ellen White on \\ Reaching the Secular Mind}

$\approx$ No fixed rules apply, all methods can be improved, we must be progressive. Ev 105
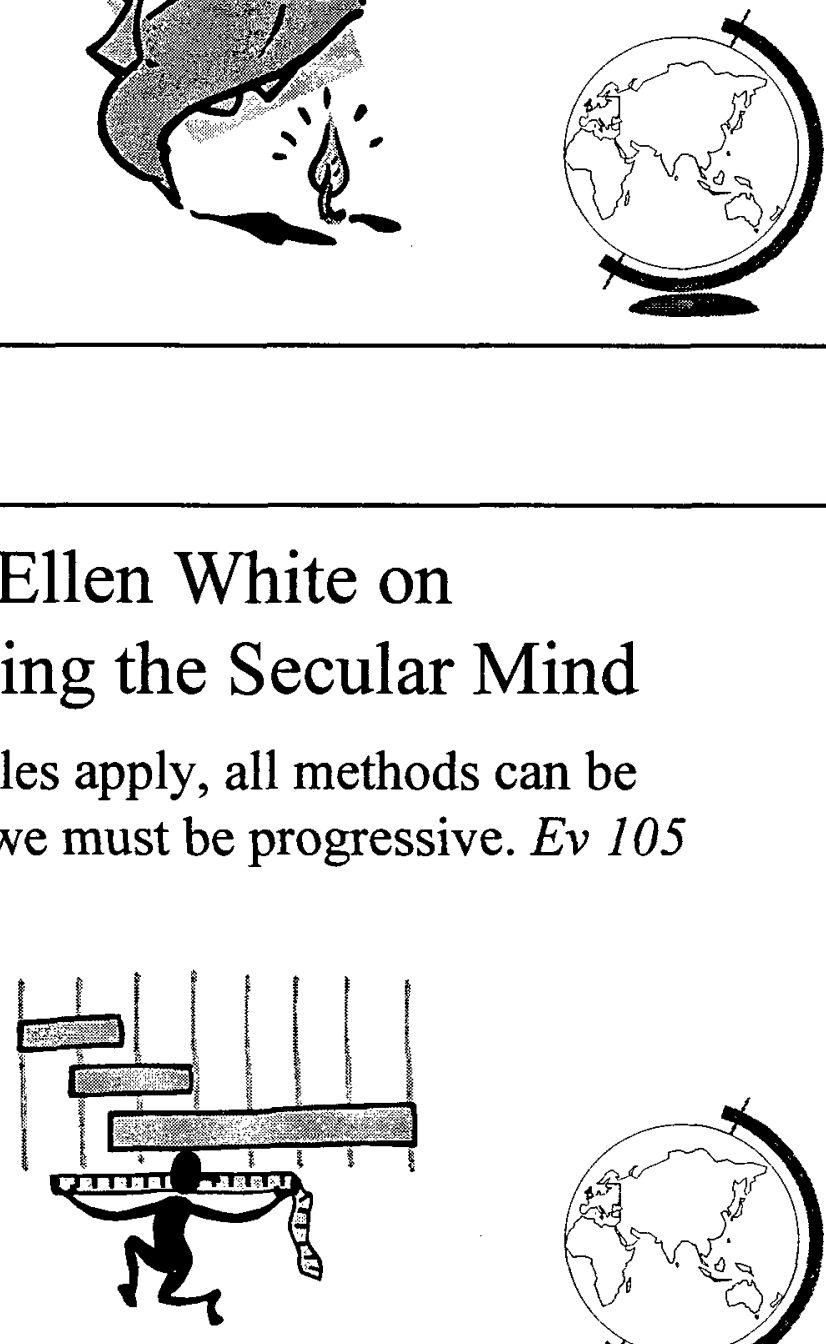


\section{Ellen White on Reaching the Secular Mind}

Christ was looking for the key to her

[Samaritan woman's] heart. DA 183

$\rightarrow$ And angels will help us to find "the key to the heart of the most incorrigible and unruly." CSW 175
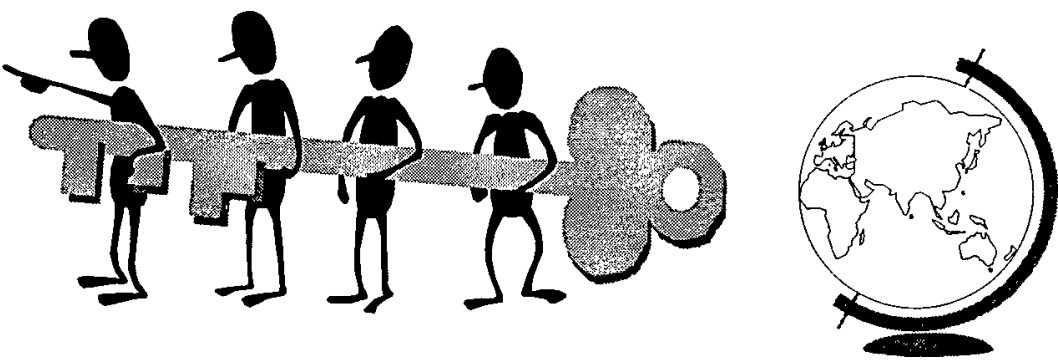

\section{Ellen White-meeting needs}

"The evidence of His divinity was seen in its adaptation to the needs of suffering humanity. His glory was shown in His condescension to our low estate." DA 217
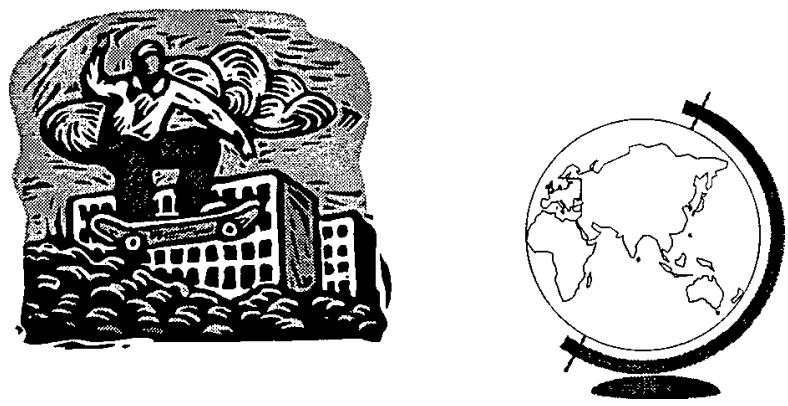


\section{Ellen White-meeting needs}

Logic and argument may not convince people of our message, but "the love of Christ, revealed in personal ministry, may soften the stony heart, so that the seed of truth may take root." CS 117

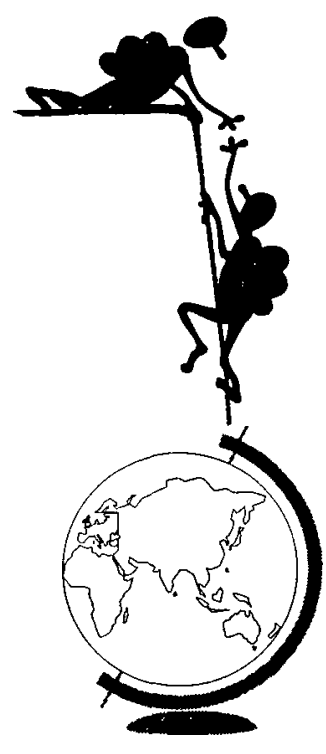

\section{Ellen White-meeting needs}

$\leftarrow$ People's "physical wants must first be relieved." CS 114
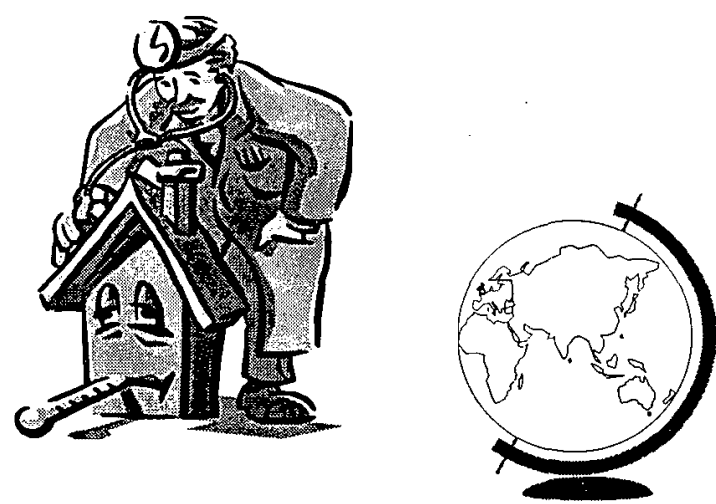


\section{Ellen White-meeting needs}

Christ's method alone will give true success in reaching the people. The Saviour mingled with men as one who desired their good. He showed His sympathy for them, ministered to their needs, and won their confidence. Then He bade them, "Follow Me." MH 143

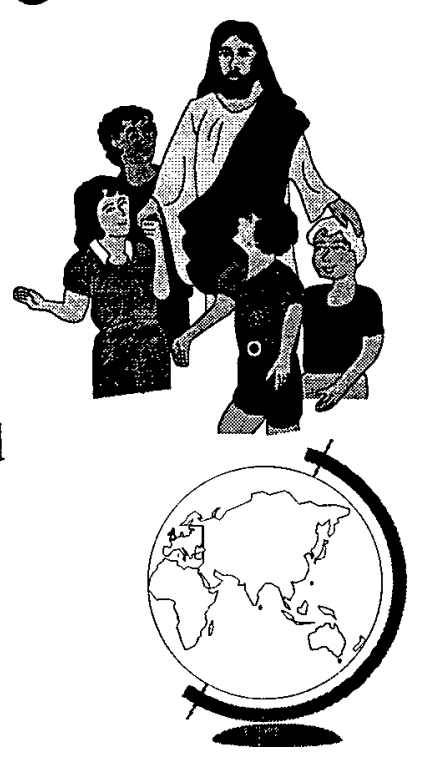

\section{Ellen White-meeting needs}

$\rightarrow$ We need to "reach the people where they are." Ev 122

$\rightarrow$ Jesus gained access to hearts through their "most familiar associations," $\mathrm{He}$ "made them feel the completeness of His identification with their interests and happiness." MH 23

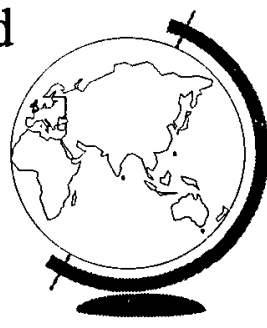




\section{Ellen White-meeting needs}

$\rightarrow$ The Israelites failed in part to bring blessings to the world because they were "untouched by the needs of those around them." PK 371
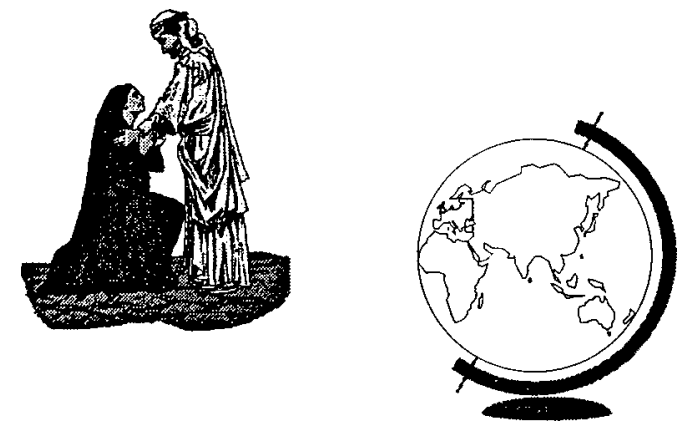

\section{Ellen White-reaching out to the} worldly person

$\rightarrow$ The life of the church "depends on the interest which its members manifest in those outside the fold." TDG 242

$\rightarrow$ To neglect this work invites "spiritual feebleness and decay." DA 825

"Many are on the verge of the kingdom, waiting only to be gathered in." AA 109

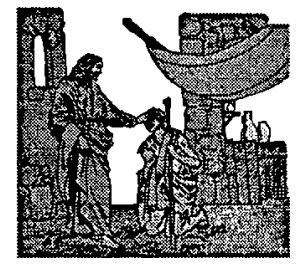




\section{Ellen White- public worship services}

The Sabbath meetings, the morning and evening service in the home and in the chapel, unless wisely planned and vitalized by the Spirit of God, may become the most formal, unpleasant, unattractive, and to the youth the most burdensome, of all the school exercises....
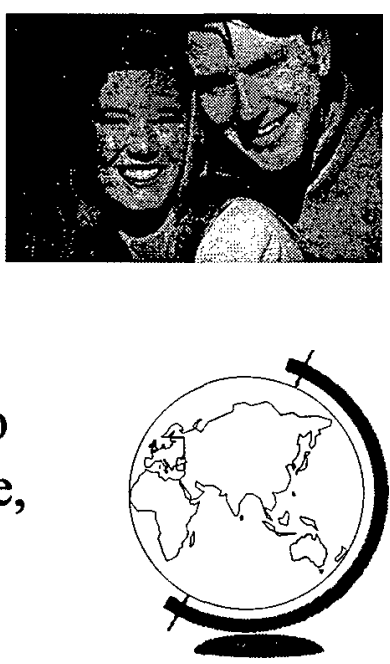

\section{Ellen White- \\ public worship services}

The social meetings and all other religious exercises should be so planned and managed that they will be not only profitable, but so pleasant as to be positively attractive. 6T 174-175
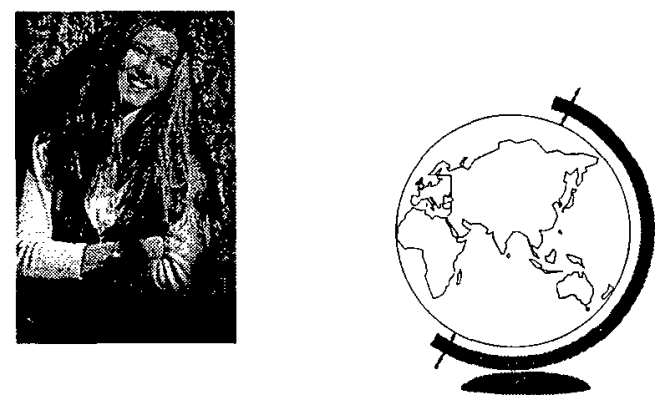


\section{Ellen White- public worship services}

The prevailing monotony of the religious round of service in our churches needs to be disturbed....
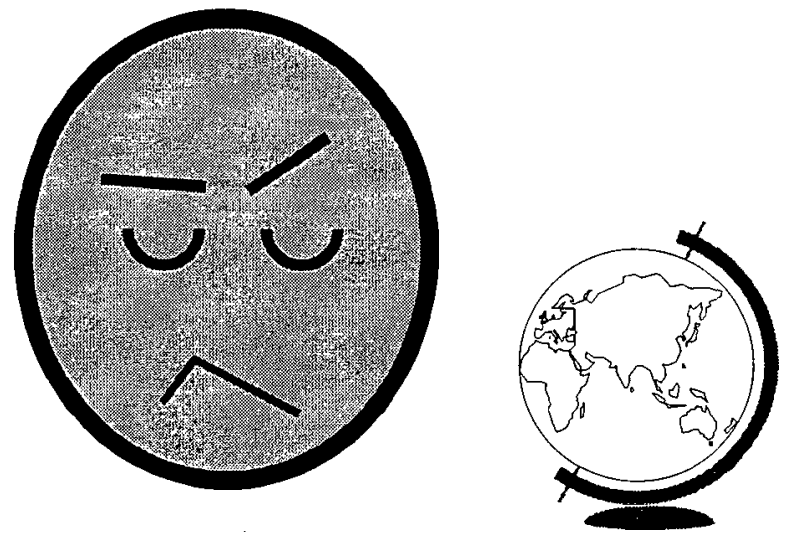

\section{Ellen White-}

\section{public worship services}

The Holy Spirit's power will move upon hearts when this dead, lifeless monotony is broken up, and many will begin to work in earnest who never before thought of being anything but idle spectators. TM 204
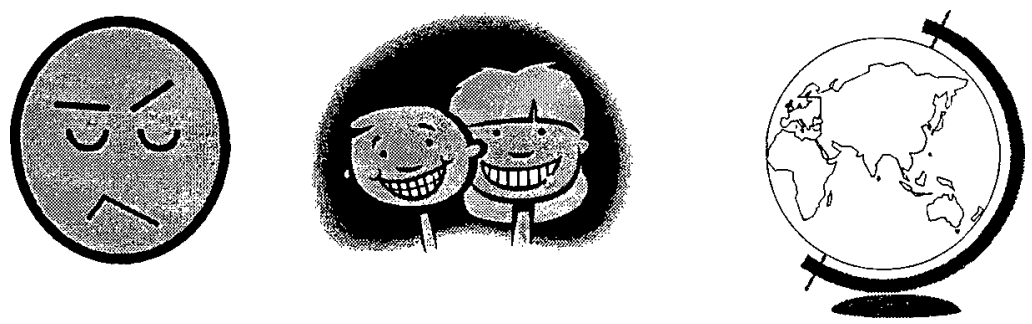


\section{Ellen White- public worship services}

"There is too much formality in our religious services.... Where the church is walking in the light, there will ever be cheerful, hearty responses and words of joyful praise." $5 T 318$ (taken from chapter "Praise Ye the Lord")

\section{Ellen White-in balance}

Like Israel, Christians too often yield to the influence of the world and conform to its principles and customs, in order to secure the friendship of the ungodly; but in the end it will be found that these professed friends are the most dangerous of foes. PP 559

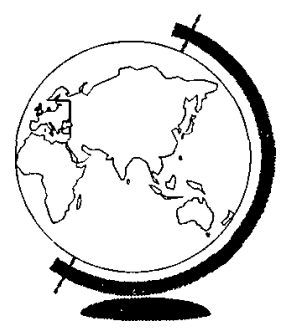




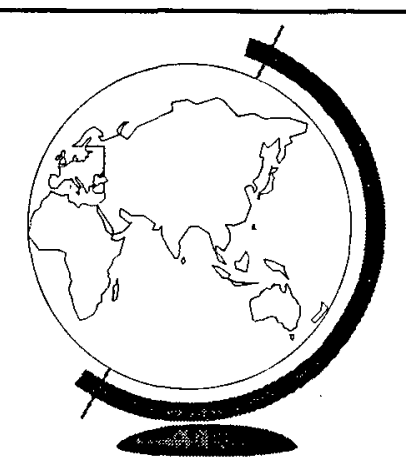

The Rest of Mankind

Reaching the $21^{\text {st }}$ century secular mind Seminar Module Five

\section{SDA's- \\ Reaching the Secular Mind}




\section{Jon Paulien}

- The incarnation declares that God meets people where they are, talks their language, and expects followers to follow suit. The gospel proclamation must be contextualized in light of the prevailing culture.
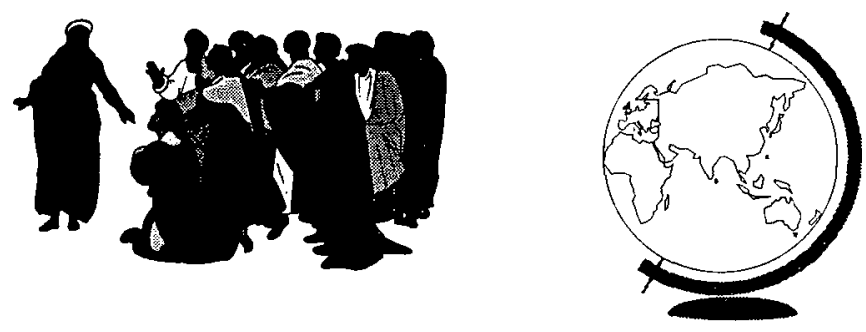

\section{Jon Paulien cont.}

- Our culture is rapidly becoming virtually Biblically illiterate. The church nowadays must speak primarily to "heathen."
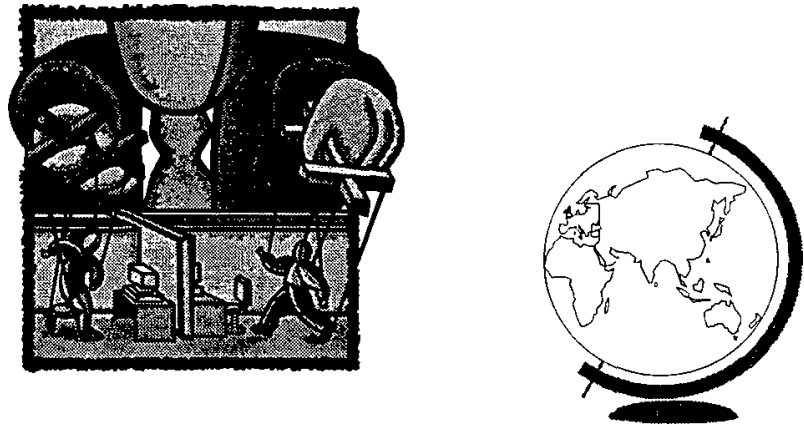


\section{Jon Paulien cont.}

Secular culture is prevalent today, even in the church. Television and other media are subtly influencing SDA church members, along with the rest of society, into secular ways of thinking.
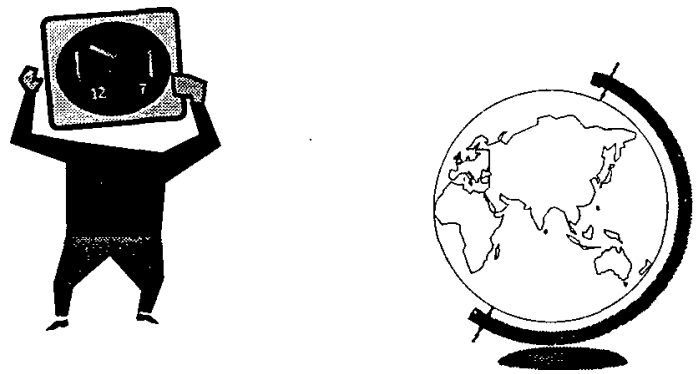

\section{Jon Paulien cont.}

$\sigma$ We need to study secularization because it may be the modern-day counterpart of Hellenization which prepared the way for Christ's first advent.
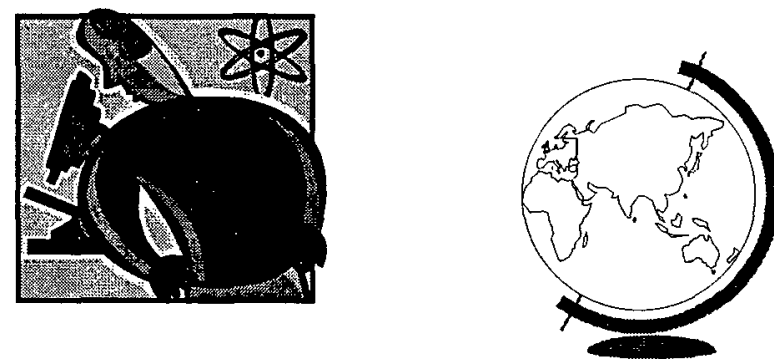


\section{Jon Paulien cont.}

$\varpi$ Four actions that the world church should take:

- Educate the entire church about its own secularization.

- Move the church towards a more effective witness.

- Teach members how to work for their neighbors and associates.

- Move out and bring in secular people.

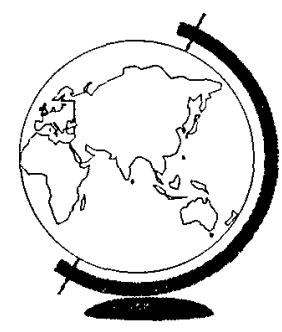

\section{Jon Paulien cont.}

The starting point is applying a specific gospel solution to a felt need. We screen out unwanted persuasion, yet when communication is directed toward a felt need, information that promises help in meeting that need is understood to be useful. It gets a person's attention.

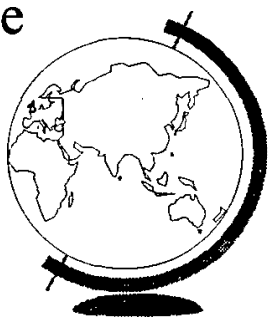




\section{Jon Paulien cont.}

$\infty$ Working with secular people is a lot of trial and error. A person must be able to identify easily with others, stimulate interest in the gospel in new and creative ways, communicate the Biblical message faithfully, and express that message in language understandable to the listener.

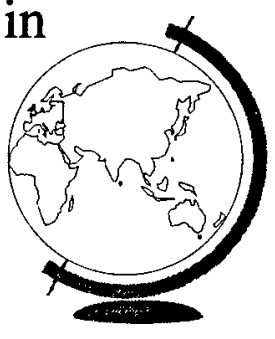

\section{Jon Paulien cont.}

- Fellowship, interpersonal small-group ministry are much more effective than institutional ministry. Secular people are rarely reached in groups; one-on-one settings are best.
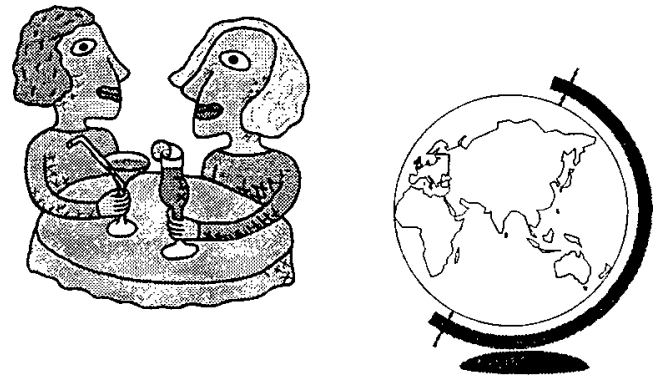


\section{Jon Paulien cont.}

- A study by Gottfried Oosterwal of Lake Union Adventist churches (published in 1976) indicated that 85 to 90 percent of all baptisms came primarily as a result of personal contact with a relative, friend, or pastor.
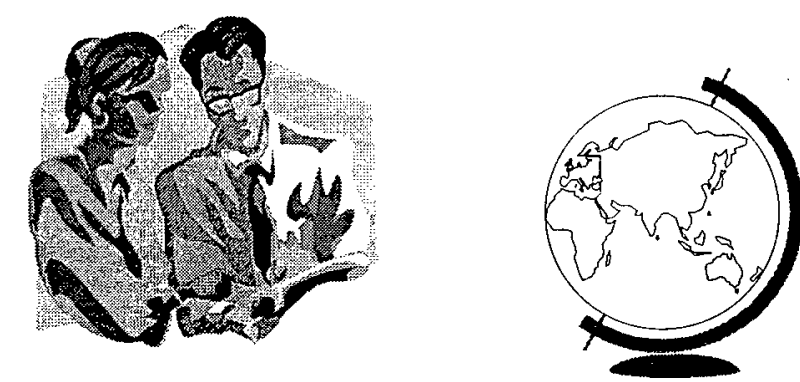

\section{Jon Paulien cont.}

$\rightarrow$ Public meetings, Adventist media, literature, and journals are considered, by those baptized, to play a significant role in less than one out of four cases. Massive lay involvement is needed in this more personal model.
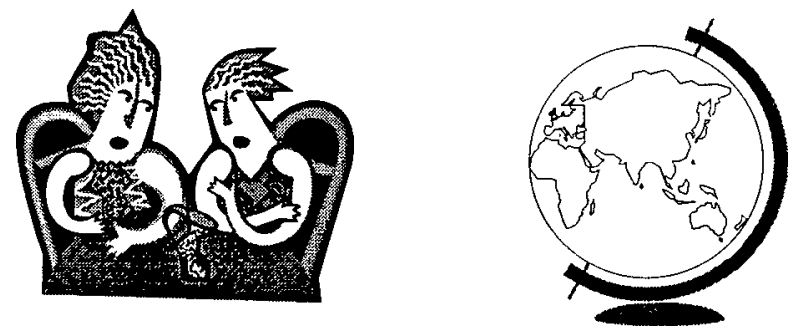


\section{Jon Paulien cont.}

We use the Sabbath-Sunday issue as the center point of many traditional Adventist evangelistic series. This issue is totally irrelevant to the secularist.

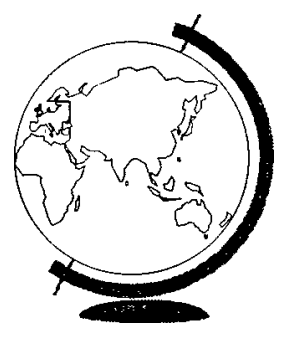

\section{Jon Paulien cont.}

- Secular people avoid the lecture approach, preferring to question, explore, ask tough questions. They prefer to negotiate their way into the faith.
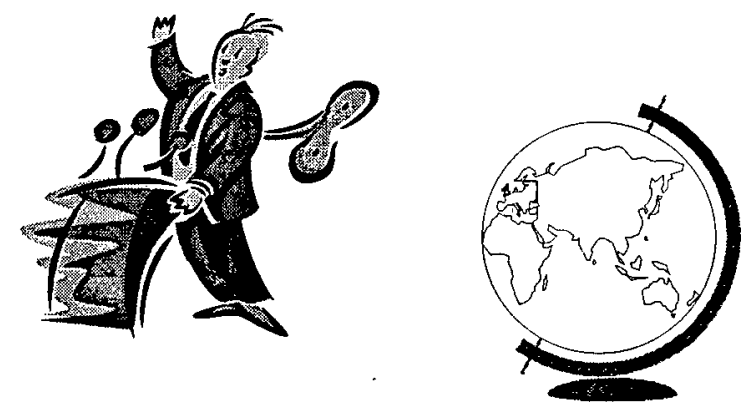


\section{Jon Paulien cont.}

- The typical Adventist worship service encourages a secular person not to come back. Practices such as "all visitors please stand (fear of commitment)," "please sign the guest book," "pass the offering plate (manipulation)," "let's sing a hymn (they do not know it)" all provide barriers. Would you like to sign a guest book at the neighborhood Buddhist temple?
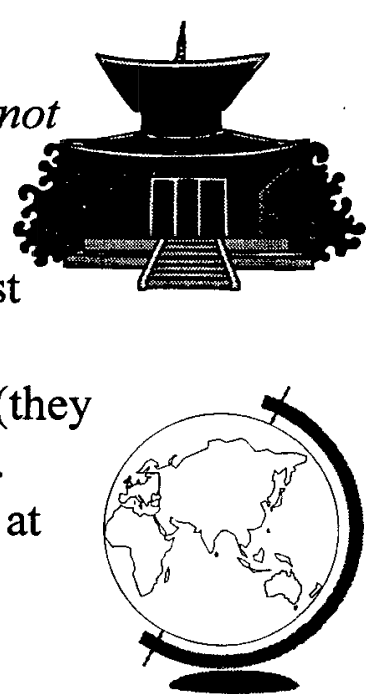

\section{Jon Paulien cont.}

$\checkmark$ In our worship services, we need to use everyday language, avoid Adventist jargon. Whatever we do on Sabbath morning needs to be highly practical, for Monday morning. We must deal with practical godliness.

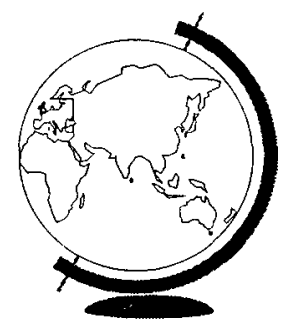




\section{Jon Paulien cont.}

$\rightarrow$ We must be concerned with excellence, for quality in everything that we do as a church. Worship needs to be more visual and attention-grabbing than before.
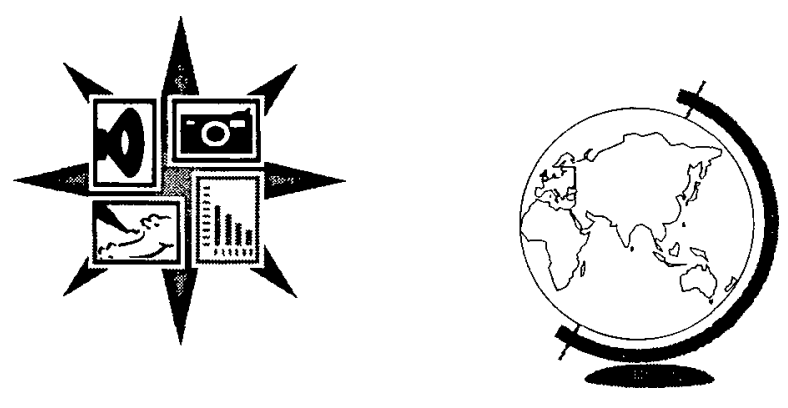

\section{Jon Paulien cont.}

$\rightarrow \quad$ In this media-saturated age, secular people are afraid of boredom. If the worship service doesn't appeal to young people, it will usually bore the secular visitor also.
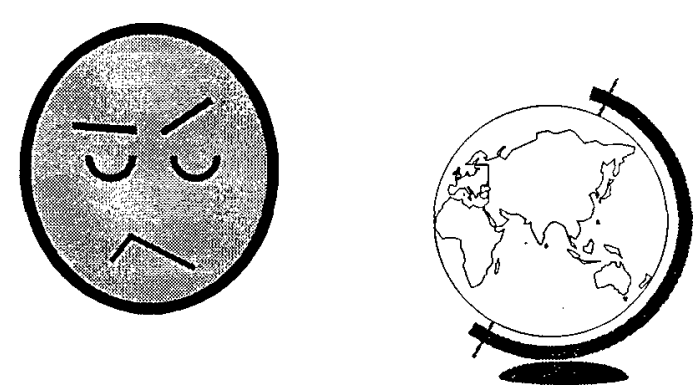


\section{Monte Sahlin}

- The three era's of Adventist evangelism.

- Prophetic.

- Institutional.

- Relational.

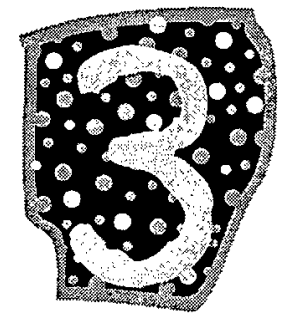

\section{Ken Cox}

$\odot$ Meeting secular people must be a "grass roots" effort, meeting them where they are: in their homes, on their streets, and in their jobs. Doing a demographic study in which we learn their nationality, age, income etc. will help in effectively targeting a specific population.
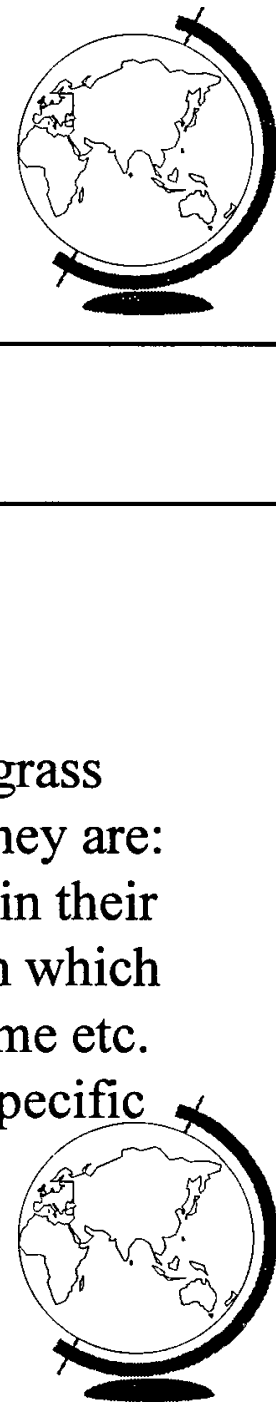


\section{Ken Cox cont.}

Results will usually be down the road. We must speak in terms of practical benefits, meeting their felt needs. Meeting felt needs will be an entering wedge to their heart. A survey can be used to discover their felt needs.
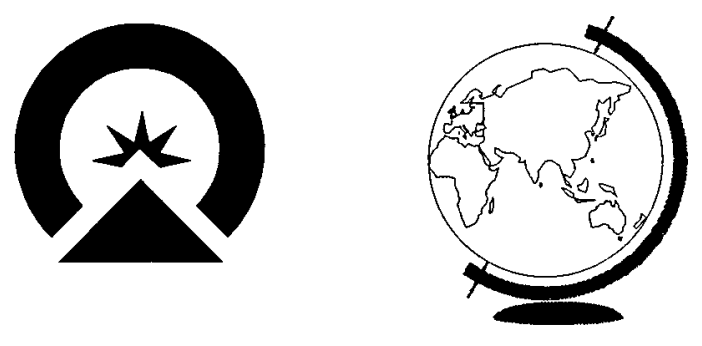

\section{Mark Finley}

$\rightarrow$ Each felt need is a point of receptivity.
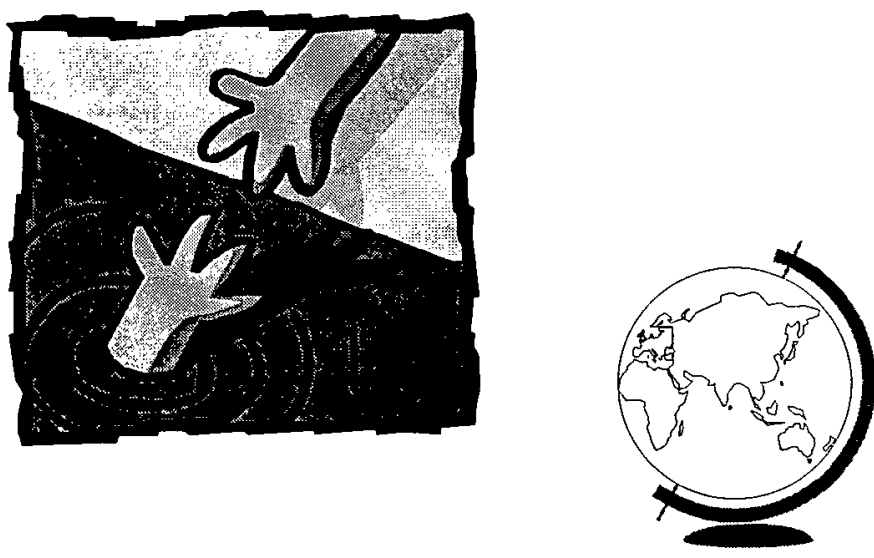


\section{Dan Matthews}

He suggests that we do not have the challenge of trying to reach "secular" minds. We need to arrest the attention of human minds.
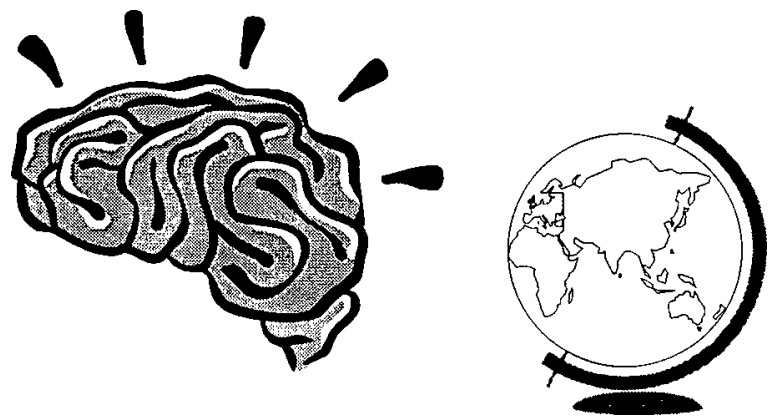

\section{Dan Matthews cont.}

- Christ's approach was to first earn the right to be heard by addressing felt needs. He answered questions people were asking in terms and tones they understood. He always met people where they were. He sought "common ground." His approach was always, "How can I help you," never "What can you do for me?"

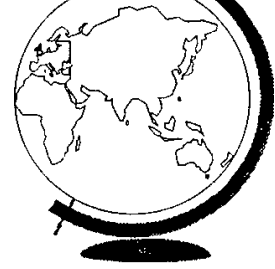




\section{Dan Matthews cont.}

- In trying to reach others, we must always ask, "Are we doing them any good?" It is never what the institutional church will get out of it.
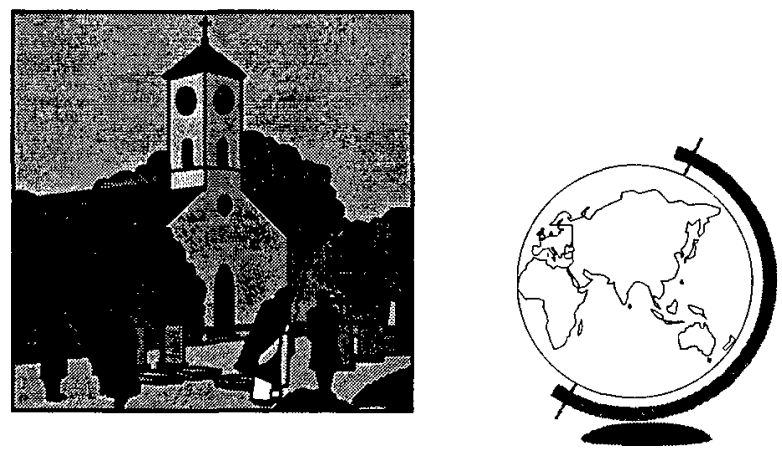

\section{Dan Matthews cont.}

- We particularly need to learn that effective marketing sells people the way they want to be sold, not the way we want to sell them. ... We must first satisfy wants before we endeavor to respond to needs. .

.. I appeal for serious marketing analysis.
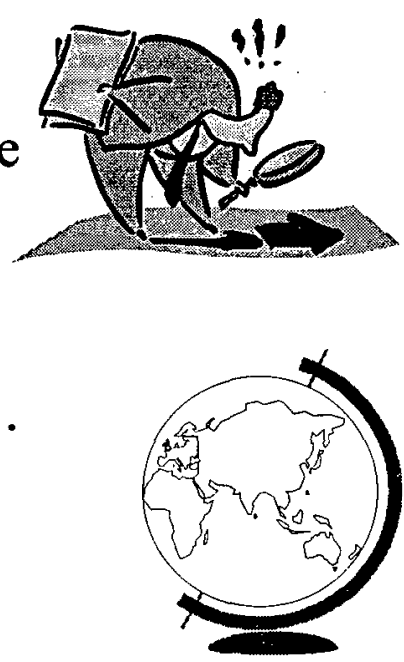


\section{Dan Matthews cont.}

$\varangle$ In reaching these people, we need to answer the questions people are asking, instead of offering solutions for which the people do not even know the questions. This requires listening for the questions, addressing them, avoiding subcultural terminologies. People must be sold what they will buy. "Scratch where it itches." We must go where the people are.
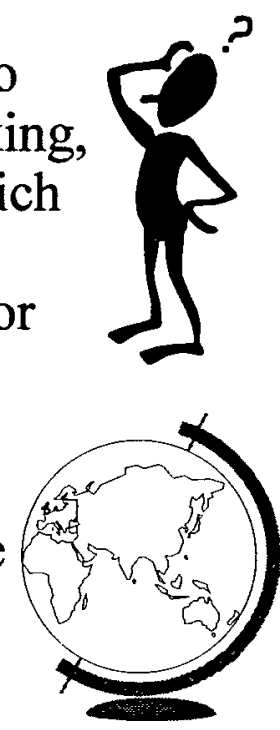

\section{Dan Day}

Effective evangelism involves strategic marketing. Successful marketing brings about organizational success through emphasizing greater responsiveness to the needs of the customer. $\sigma$ Marketing starts with the customer.
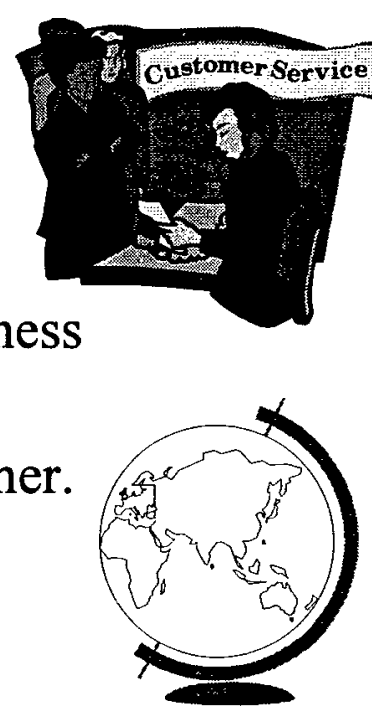


\section{Dan Day cont.}

Essentially, marketing starts with the consumer of whatever products or services the organization is offering-asking pertinent questions about who the customer is, what the customer wants and needs, how the customer perceives the organization-and then goes on to use this information to guide how all systems are designed and all products are developed and offered.

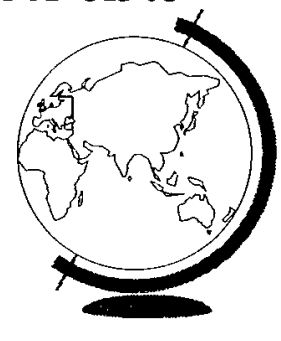

\section{Dan Day cont.}

People today are going to churches that are marketing themselves most effectively.

Mainline churches, as well as SDA churches in North America, are losing their appeal.
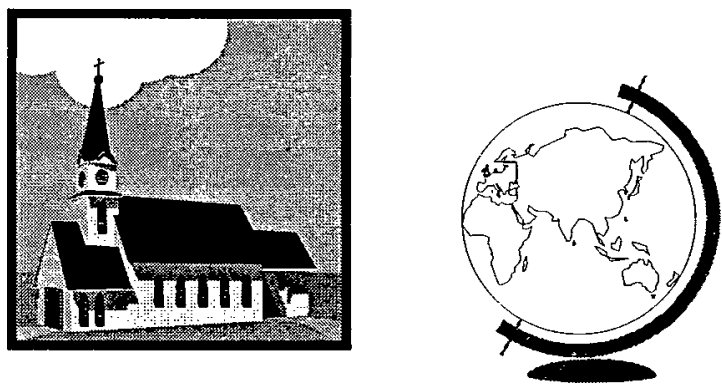


\section{Dan Day cont.}

For too long, we've been satisfied to blame the relatively slow advance of Adventism here in America on sociological factors beyond our control. "We live in a secular world," we've argued. "People don't want to hear the truth." To some degree this is true, of course. But could it be that they are also wearied, offended, or disenchanted by the way we've packaged our message?

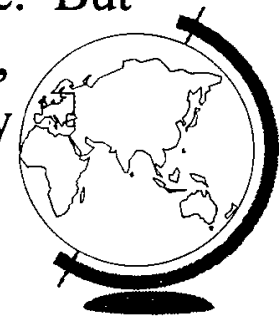

\section{Dan Day cont.}

We have been trying to sell Adventism when we should have been trying to market it. Marketing makes selling superfluous. A marketer knows and understands the customer so well that the product fits and sells itself.
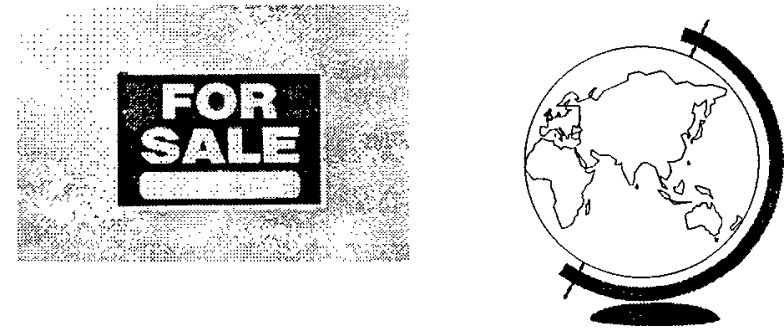


\section{Dan Day cont.}

- There are some in the church who would argue that all we can do is sell Adventism, since the character of our product is set. These are our beliefs, and we're not about to change them, no matter what. ... But such an attitude, when applied to our ministry to a lost world, is remarkably shortsighted. .

\section{Dan Day cont.}

God's message to us is a need-satisfying message. To the degree that we don't couch it in those terms when we communicate to others, we're confusing people and doing the Lord a disservice.

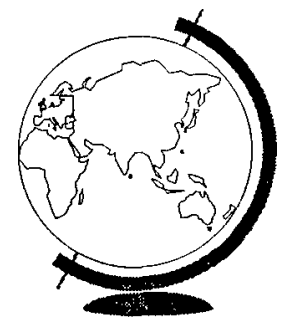




\section{Dan Day cont.}

$\rightarrow$ The issue is not whether or not we change our beliefs or reorganize our church. It's whether or not we've understood our customers' needs well enough to show how what we have matches what they need.

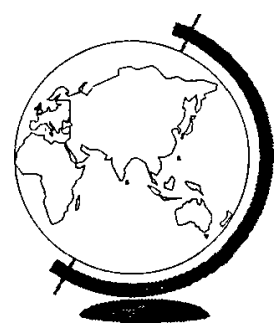

\section{Dan Day cont.}

Marketing Adventism is everybody's business, not merely the pastors. We need to catch the vision of a church filled with Christian marketers. And we market best right where we are, in our own circle of friends, business associates, and fellow-travelers.

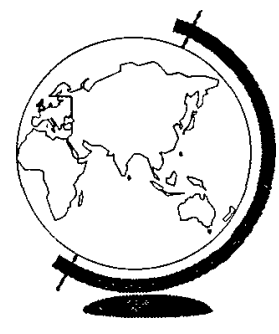




\section{John Fowler}

$\leftarrow$ He quotes Roy Allan Anderson's article in Ministry which spoke of the Adventist evangelistic approach in the 1930's as being "unfortunate." A program of subjects, presented in a startling manner, lasting for weeks or months was presented to perspective members. They drank it in, many were baptized at the end of this "series."

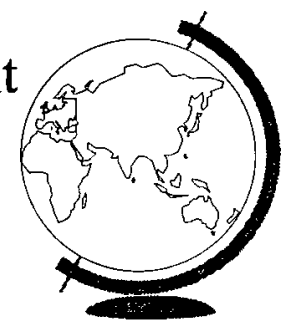

\section{John Fowler cont.}

However, in this cram session, the people were not able to assimilate all of these truths in the short time allotted. They had been startled, convicted, they felt compelled to act. They were denounced as heretics if they did not accept all the truths presented and join the church. It was a manipulative and divisive approach, it engendered a spirit of criticism and judgment among the members that ill-prepared them to care for the new members. 


\section{John Fowler cont.}

- He quotes Elder A. C. McClure, former NAD President:

An argumentative approach reverses this (Christ's) method. We somehow conclude that if we could convince people of our doctrines they would want to join our fellowship. But a bit of reflective thinking about how society works would belie this notion....

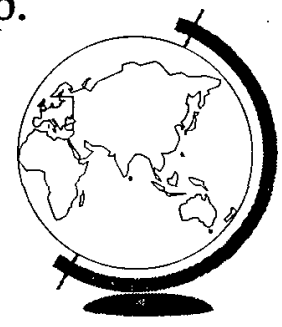

\section{John Fowler cont.}

In fact, just the opposite is true. If we would bring people into our fellowship, then they would want to know our doctrine.
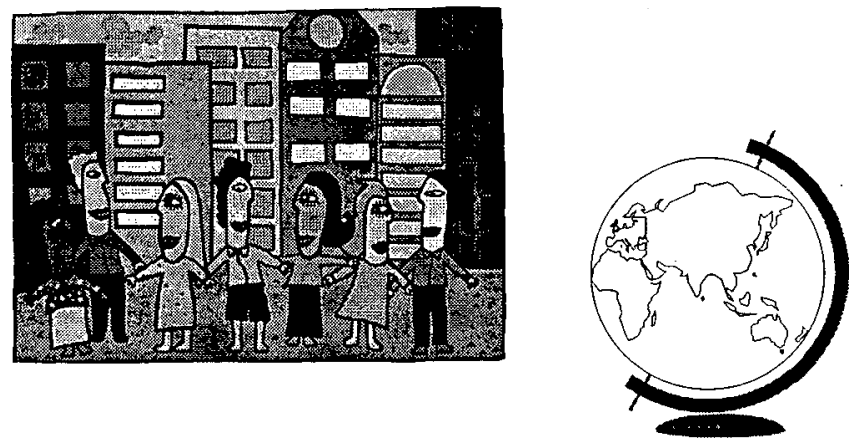


\section{John Fowler cont.}

$\rightarrow$ We must accept people, bring them into our fellowship, become their friends. Then they will want to know our doctrines, be baptized, and become a part of the church family. Jesus focused on meeting the needs of the people. And the result? People willingly followed Him because $\mathrm{He}$ loved them, ministered to their needs, and they believed His teachings.

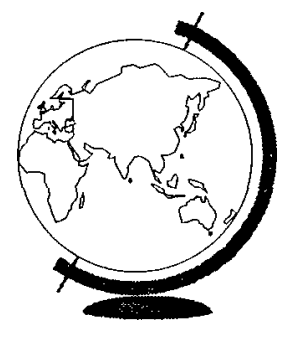

\section{John Fowler cont.}

We need to go among the people as Jesus did, desiring their good. Small group ministries are very effective in meeting people's fellowship needs.
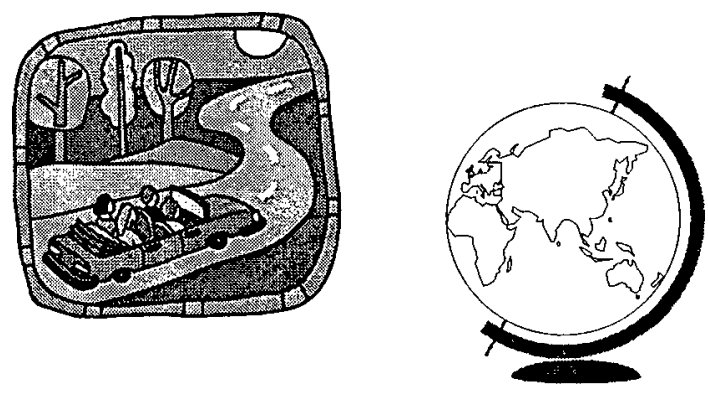


\section{John Fowler cont.}

We must stop "converting" people to Adventism through rational, propositional truths alone. They must be truths couched in Jesus. The gospel does not consist primarily of doctrinal truth, it is a relationship with Jesus.

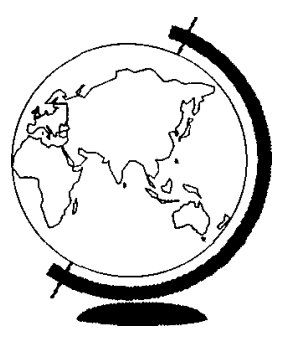

\section{John Fowler cont.}

$\sigma$ For a person to merely adopt a certain doctrinal viewpoint will accomplish little or nothing. Converts cannot exist in society and maintain Christian values unless they are a part of a community that reinforces those values. Everybody needs a friend.
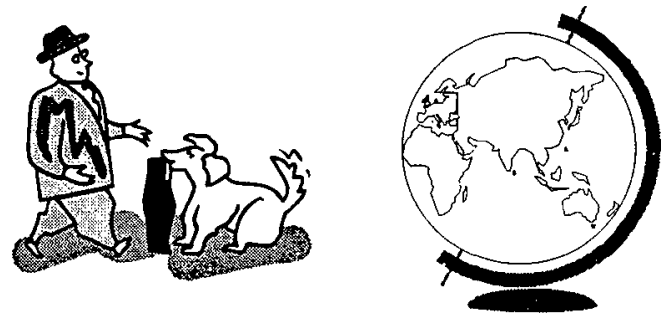


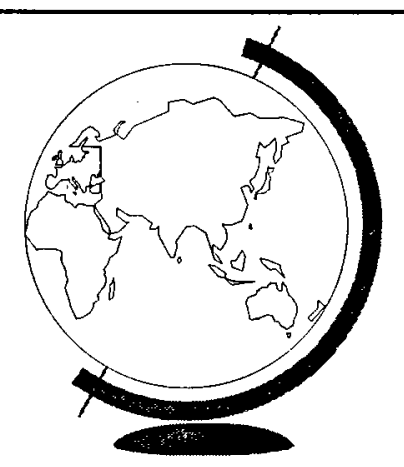

The Rest of Mankind

Reaching the $21^{\text {st }}$ century secular mind Seminar Module Six

\section{Evangelical Literature on Reaching the Secular Mind}




\section{George Hunter III}

For centuries the Church was harvesting grain in fields already plowed, seeded and watered. But today, we need to first plow, seed, and water the fields before we can expect to gather a harvest.
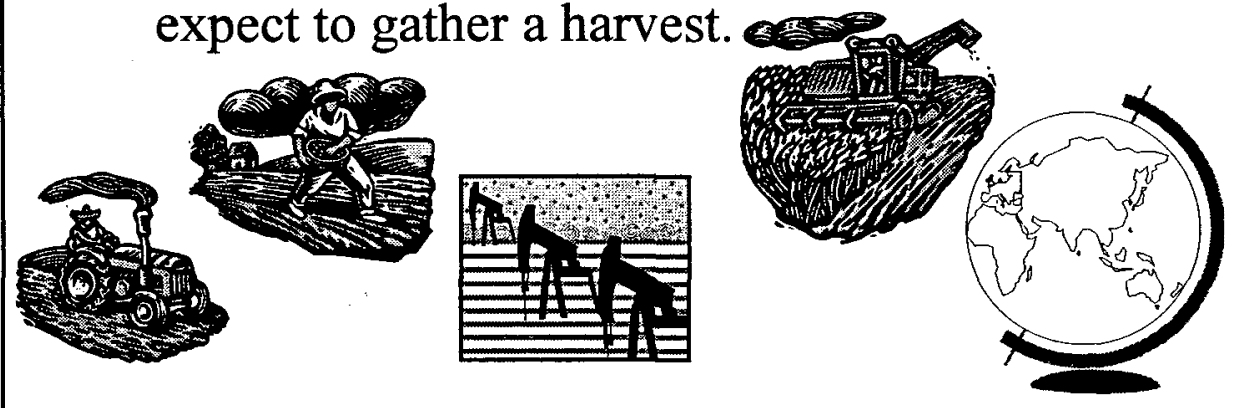

\section{George Hunter III}

- The secularization of the West has positioned the Church into a missionary role here at home. In fact, the West is the toughest mission field on earth.
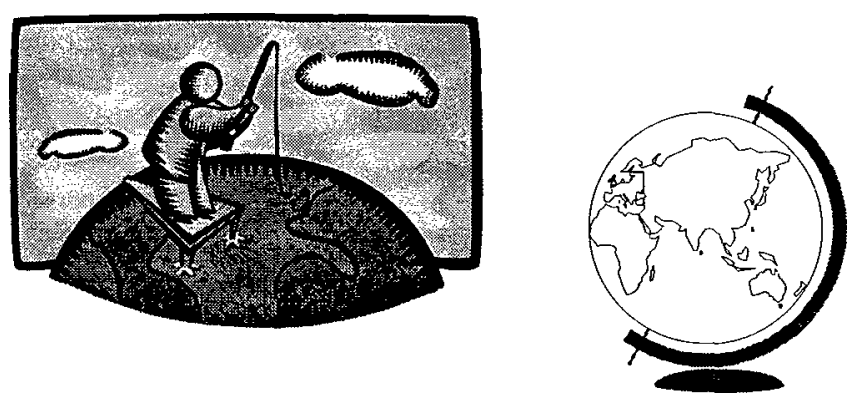


\section{Hunter's 17 strategies for reaching secular people}

1. We need to provide ministries of instruction.

2. Invite people to dedicate their lives.

3. Help secular people find meaning.

4. Engage secular people in dialogue.

5. Address secular people's doubts and questions.

6. Provide opportunities to meet credible Christians.

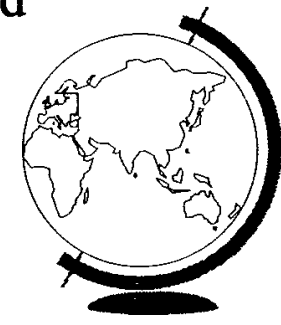

\section{Hunter's 17 strategies for reaching secular people}

7. Provide opportunities for people to overcome alienation.

8. Engage in ministries of affirmation.

9. Help people discover their dignity and selfworth.

10. Offer people hope in the Kingdom of God.

11. Provide support groups for people with addictions.

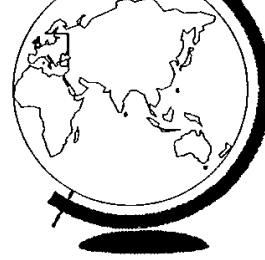




\section{Hunter's 17 strategies for reaching secular people}

12. Identify and reach receptive people.

13. Reach across social networks.

14. Offer culturally appropriate forms of ministry.

15. Multiply "unites" of the Church.

16. Offer ministries that meet needs.

17. Engage secular people on "their turf."

\section{Hunter's 10 ideas that help avoid "turf mistakes."}

1. Active listening.

2. First engage people on neutral turf, or on their turf.

3. Relate to seekers as a friend and ally, not an adversary who is out to "win" them.

4. Do not try to do all the communicating.

5. Speak early to the questions, unmet needs, and unfulfilled motives that drive secular people's lives. 


\section{Hunter's 10 ideas that help avoid "turf mistakes."}

6. Communication of the christian's message's meaning takes place, by cumulative effort, over time.

7. Personalize the message.

8. Do not put the pressure on for a decision.

9. There is communication value in word plays, proverbs, and other maxims.

10. Tell stories.

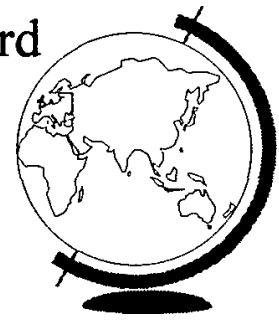

\section{Robert Schuller's formula}

1. The unchurched people's needs will determine our programs.

2. The unchurched people's hang-ups will determine our strategy.

3. The unchurched people's culture will determine our style.

4. The unchurched population will determine our growth goals.

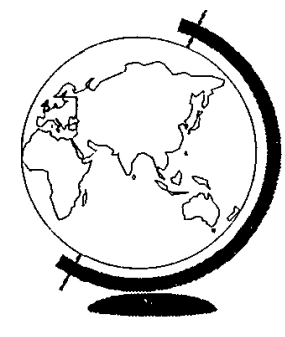




\section{Bill Hybels}

The typical traditional church is no place for the unchurched. To anybody but the already convinced, the average church service seems grossly abnormal. It makes no sense to those who haven't grown up in it, to those who do not know the drill. The music we sing, the titles we choose, the way we dress, the language we use, the subjects we discuss, the poor quality of what we do - all of these lead the average unchurched person to say, "This is definitely not for me."

\section{Bill Hybels' seven-step process}

1. Build an authentic relationship with a nonbeliever.

2. Share a verbal witness.

3. Bring the seeker to a service designed especially for them.

4. Regularly attend a service for believers.

5. Join a small group.

6. Discover, develop, and deploy your spiritual gift.

7. Steward your resources in a God-honoring way. 


\section{Lee Strobel's 15 characteristics of unchurched "Harry"}

1. Harry has rejected church, but that doesn't necessarily mean he has rejected God.

2. Harry is morally adrift, but he secretly wants an anchor.

3. Harry resists rules but responds to reasons.

4. Harry doesn't understand Christianity, but he's also ignorant about what he claims to believe in.

5. Harry has legitimate questions about spiritual matters, but he doesn't expect answers from Christians.

6. Harry doesn't just ask, "Is Christianity true?" Often, he's asking: "Does Christianity work?"

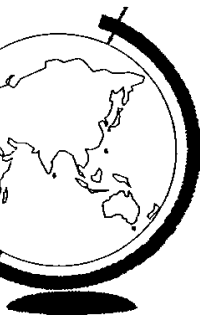

\section{Lee Strobel's 15 characteristics of unchurched "Harry"}

7. Harry doesn't just want to know something; he wants to experience it.

8. Harry doesn't want to be somebody's project, but he would like to be somebody's friend.

9. Harry may distrust authority, but he's receptive to authentic biblical leadership.

10. Harry is no longer loyal to denominations, but he is attracted to places where his needs will be met.

11. Harry isn't much of a joiner, but he's hungry for a cause he can connect with.

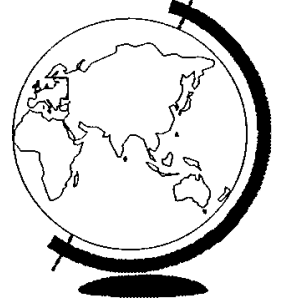




\section{Lee Strobel's 15 characteristics of unchurched "Harry"}

12. Even if Harry's not spiritually sensitive, he wants his children to get quality moral training.

13. Harry and Mary are confused about sex roles, but they do not know that the Bible can clarify for them what it means to be a man and woman.

14. Harry is proud that he's tolerant of different faiths, but he thinks Christians are narrow-minded.

15. There's a good chance Harry would try church if a friend invited him-but this may actually do him more harm than good.

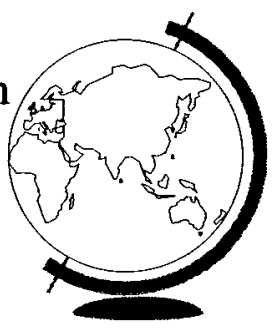

\section{Lee Strobel's 7-step strategy to reach unchurched "Harry"}

1. Believing Bob tells Unchurched Harry how God has changed his life and, to the best of his ability, seeks to communicate the Gospel over time.

2. Believing Bob invites Unchurched Harry to a service designed for seekers and answers his questions and concerns.

3. Once Harry commits himself to Christ, he begins attending a worship service geared for believers.

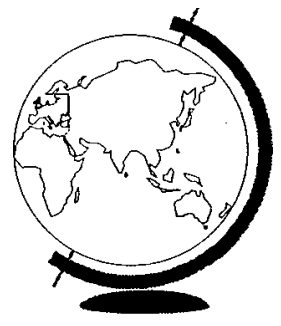




\section{Lee Strobel's 7-step strategy to reach unchurched "Harry"}

4. Once Harry commits himself to Christ, he begins attending a worship service geared for believers.

5. Harry joins a small group designed to help him grow spiritually.

6. Harry discovers, develops, and deploys his spiritual gift in order to honor God and to build the church,

7. Harry begins stewarding his resourcestime and money-in a godly fashion.

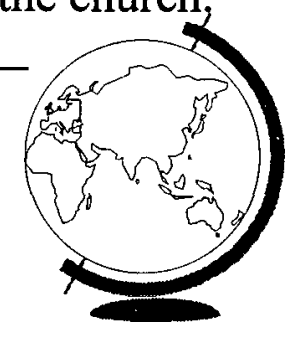

\section{Lee Strobel cont.}

Unchurched people's number-one value is anonymity. They dread being placed on a mailing list, prefer small groups, they like exciting, insightful, daring, creative, aweinspiring and celebratory worship services.
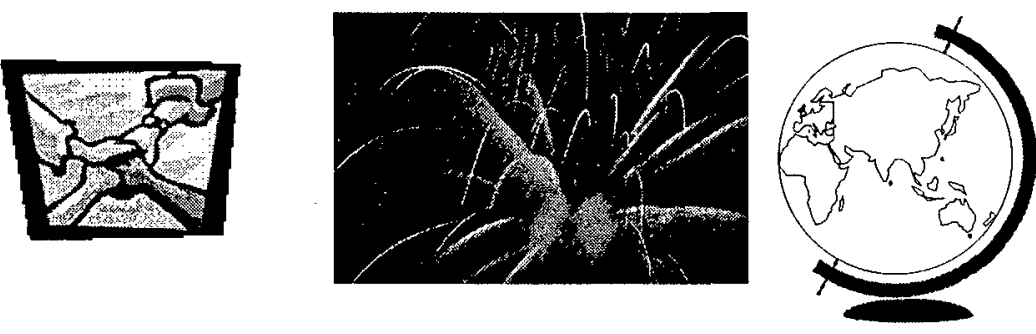


\section{Lee Strobel cont.}

$\$$ They are connected with the TV generation. They crave visual stimulation. Print is out, many do not even read. Linear thinking is out; experiential is in. The more senses used in reaching them, the greater the impact. Quality counts, they expect excellence. When asked what could bring them into a church, the Number One response was "better messages."
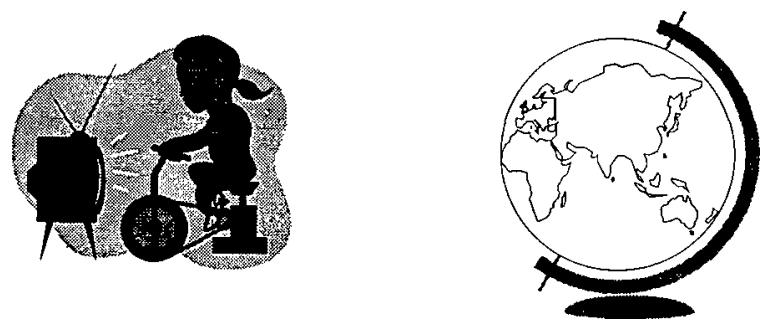

\section{Leith Anderson}

He writes in his book "Dying for Change" that an estimated 85 percent of America's Protestant churches are either stagnating or dying. The communicator must make the Bible relevant to be heard. The church has the responsibility to understand both the people and the culture in which they live. The Bible must be made relevant to today's culture.
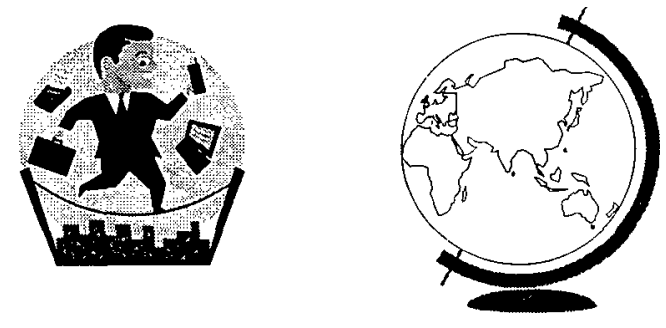


\section{Leith Anderson cont.}

The rise of consumerism and consumer advocacy is the greatest factor in denominational decline. People shop around now for the church that meets their needs. They aren't loyal to a particular denomination or neighborhood church.
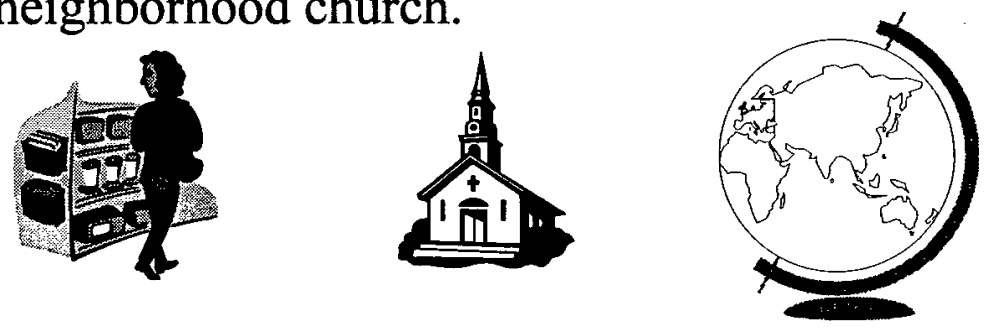

\section{Leith Anderson cont.}

We must change the starting point of evangelism.

People use to have some kind of religious background, familiar with basic Christian ideas and vocabulary. That landscape is rapidly changing. Millions of Americans have never been to church, never cracked a Bible, have no interest in or sense of need for religion. We must go to them, attract them, start where they are instead of where we wish them to be.

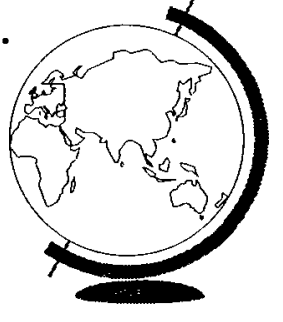




\section{Leith Anderson cont.}

Today's churches must be open to new ideas and changing structures, realizing that many areas are cultural relatives, not moral absolutes. Yesterday's answers may not be appropriate for today's mindset. Fulfilling our mission supercedes perpetuating traditions.
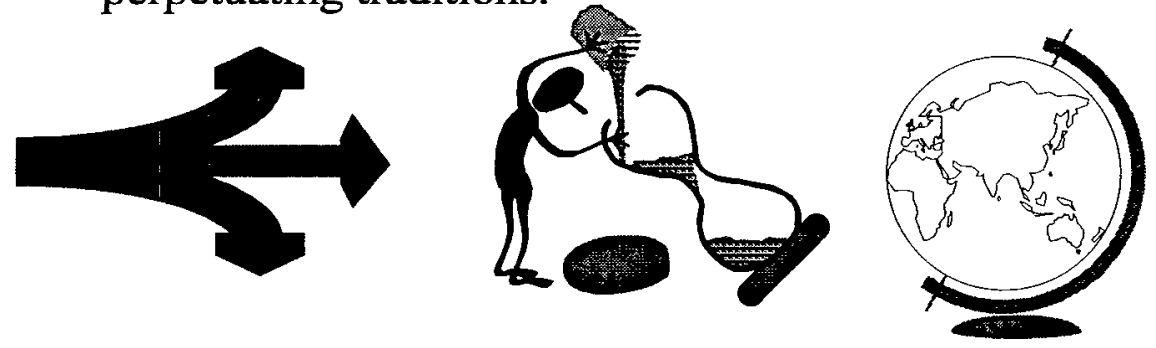

\section{Leith Anderson cont.}

Balanced with that, we must remember the lessons of the past (heresies, failures). There are absolute truths that supercede private preferences. Secular values must not be allowed to take root and grow in the church, or they will endanger the continuation of biblical standards of truth and practice.
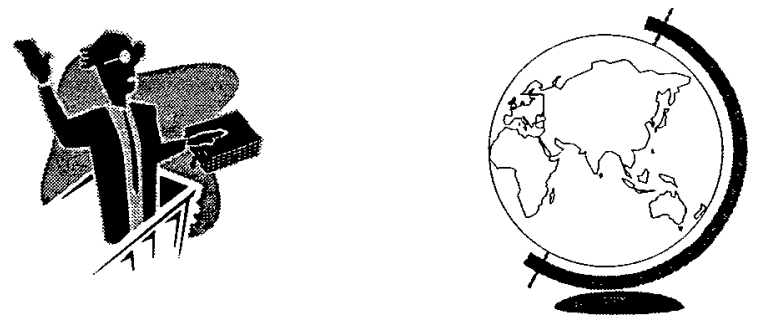


\section{Leith Anderson cont.}

There is a growing polarization among evangelicals. In one camp cluster the monasticsthose who stick to "truth and tradition." Yet they are isolated from society. In the other camp cluster post-Christian secularists, sociologically relevant but no longer truly Christian.
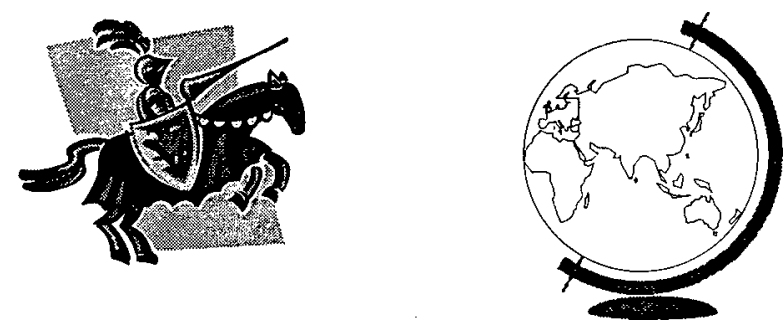

\section{Leith Anderson cont.}

A local church needs to learn the market, do a demographic study and mold their ministry to a target population. Decide on the nonnegotiables. They are directly from God; everything else is negotiable. Changes must fit both the purpose and the market.
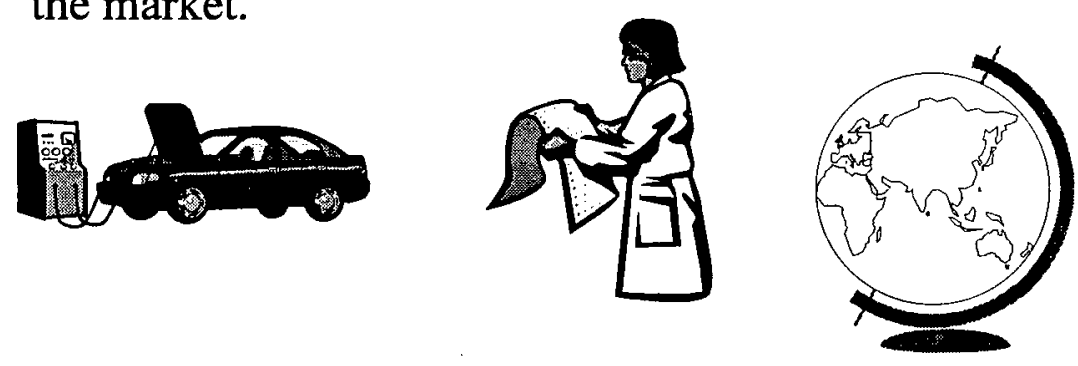


\section{Leith Anderson cont.}

Successful traditional churches will need to incorporate many contemporary elements, including services to consumers and meeting modern needs. They will need to do the traditional with a high level of excellence.
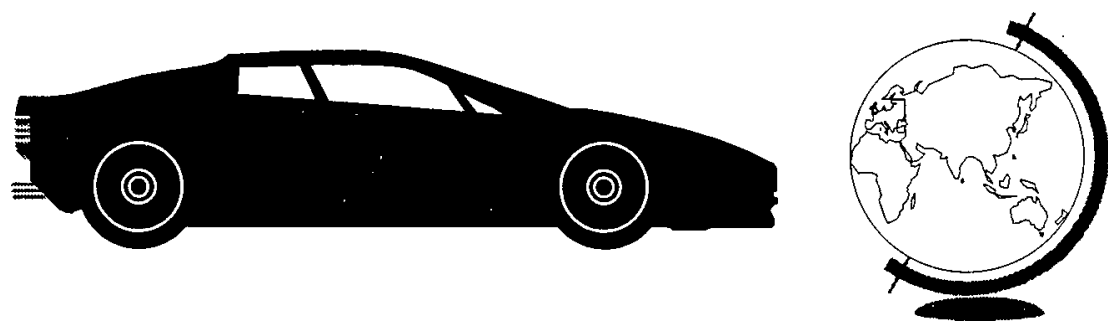

\section{Leith Anderson cont.}

To many older Christians "contemporary" means new, and they do not like it. To many younger Christians "contemporary" means new, and they do like it.

$\checkmark$ Contemporary, however, is merely a contrast to traditional. It means that it originated during the present generation rather than inherited from a previous generation. It is not better or worse; it is just later.

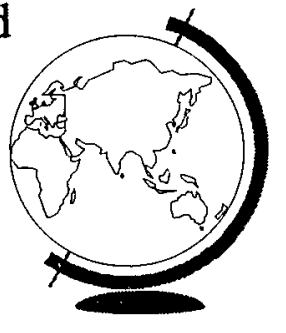




\section{Leith Anderson cont.}

The essential exercise for every church leader is to first understand the culture and then translate the meaning of the message into that culture.
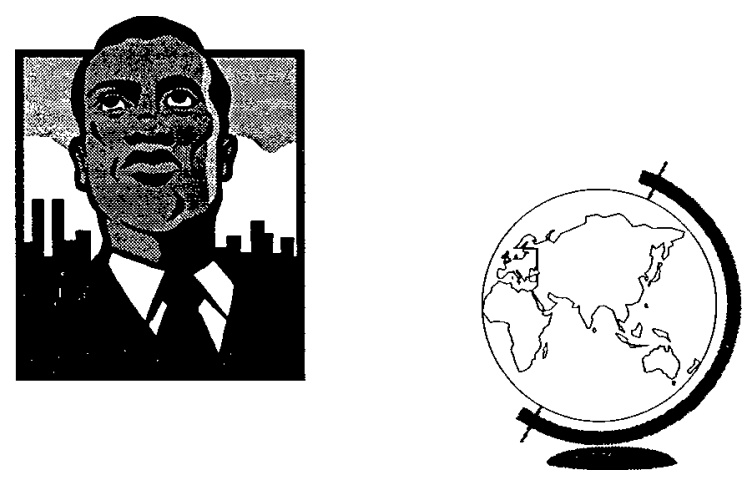

\section{Leith Anderson cont.}

5 Contemporary churches are those that relate to people in terms of today's culture rather than in terms of yesterday's traditions. Neither today's culture nor yesterday's traditions are necessarily right or wrong.
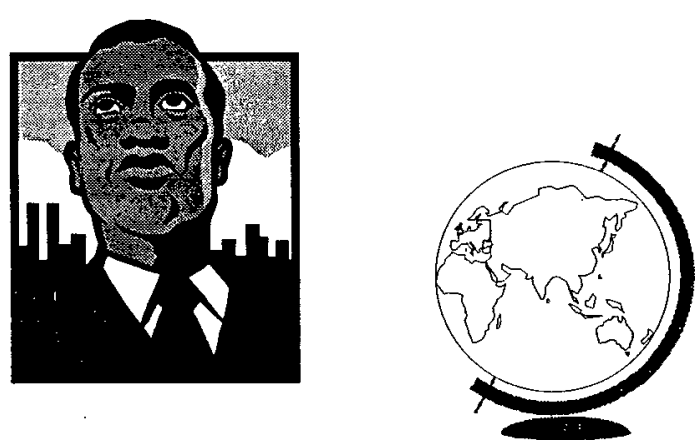


\section{Leith Anderson cont.}

Yesterday's style (sermon) was oratorical, formal, loud, polished, intense, used significant historical illustrations, and told people what to do. Today's style is much more conversational, much like the monologue of Johnny Carson or Jay Leno on the Tonight Show.
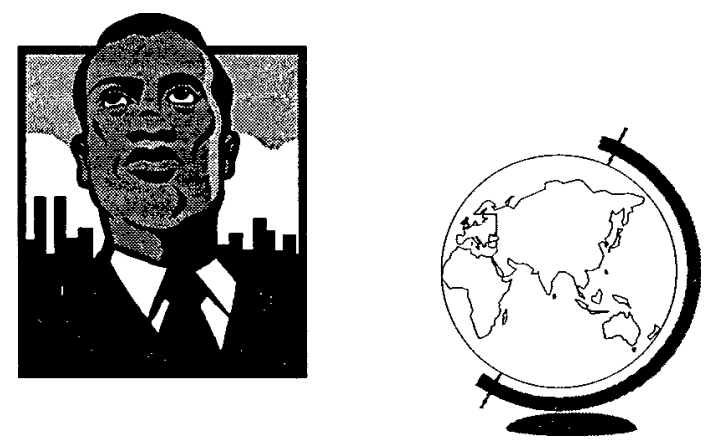

\section{George Barna}

Describe his illustration "The Frog in the Kettle."
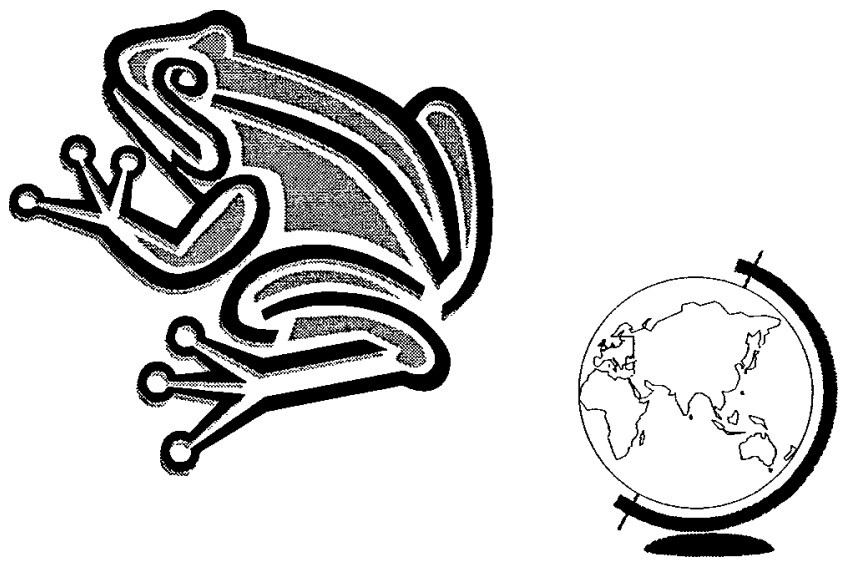


\section{George Barna}

The Christian community, in the midst of a whirlpool of change and a hostile societal environment, is losing the battle. Charged by Christ Himself to be agents to change the world rather than agents changed by the world, we have been mesmerized by the lures of modern culture. Rather than prepare for the coming battles, we revel in past victories, focusing on what can never be changed or relived, at the expense of tomorrow's opportunities. Change is now a constant in America.

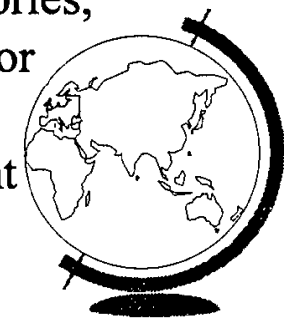

\section{George Barna cont.}

The old approaches and traditional strategies for sharing our faith will no longer work in the ' 90 s. We have to be clever enough to analyze our environment and provide creative responses to the challenges we face.
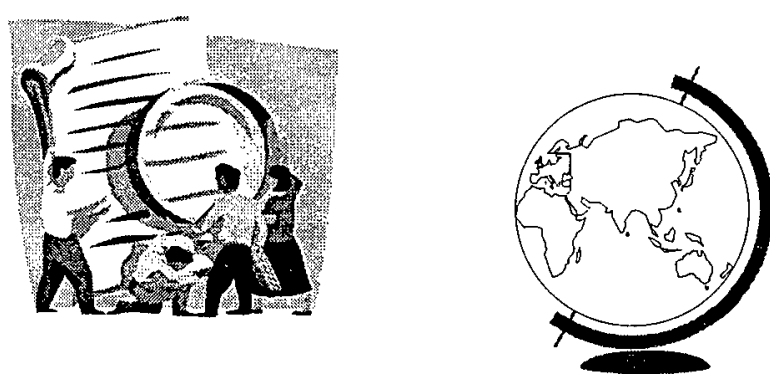


\section{George Barna cont.}

Typically, we have been five to ten years behind society, responding to changing conditions long after transitions have begun. And now we have run out of time. If we want the Christian faith to remain a vibrant alternative to the world system, we must stop reacting and start anticipating.
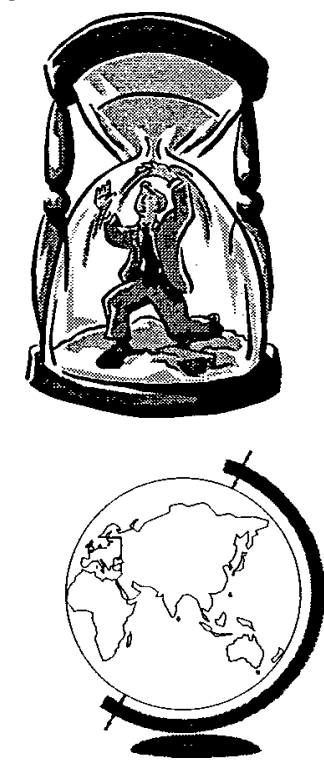

\section{George Barna cont.}

We must keep in mind Paul's suggestion that we must be sensitive to our culture, adapting our approaches without compromising our message. America's superficial spirituality demands that we rededicate ourselves to proclaiming the gospel in new ways that are relevant to people's lives.

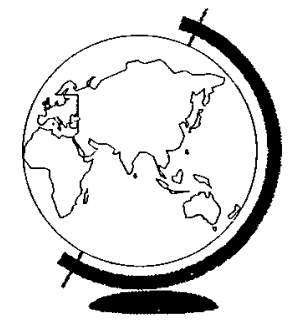




\section{George Barna cont.}

$\checkmark$ It will be increasingly difficult to convince the unchurched that our faith is pertinent to the twenty-first century if the tools of our trade are from the last century.
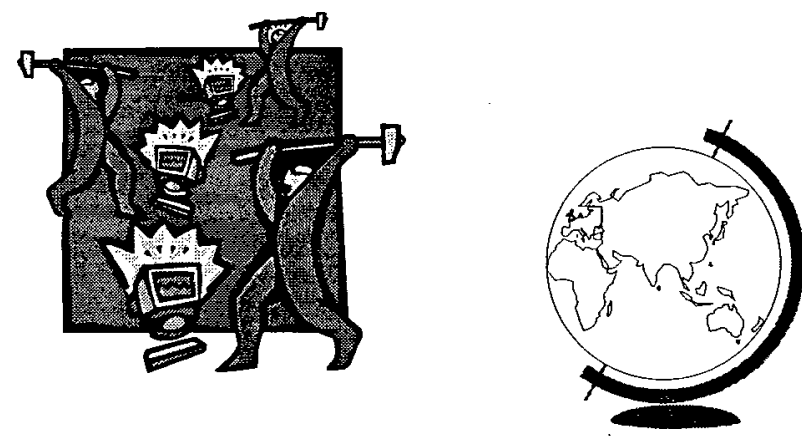

\section{George Barna cont.}

Churches must base their ministry upon the felt needs of the audience. Yet one of the glaring weaknesses of the Church has been in the area of discipling and accountability. We will be tempted to downplay the importance of commitment and obedience. We will be tempted to soften the truth so that a hardened generation will give us a fair hearing. There is a fine line between clever marketing and compromised spirituality.



\section{George Barna cont.}

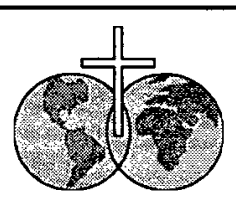

Does this mean we should not attempt to repackage the gospel in ways that may be more attractive to nonbelievers? No? We must do so if we hope to get our message to emerge from the flood of commercial messages that are directed at us each day. Our goal, however, must be to describe the faith in ways which are clearly relevant to today's circumstances and tensions, but without minimizing the hard truths that Jesus taught and demands of us. In a society that does not recognize absolutes, we must make absolutes seem not only relevant but natural and appealing.

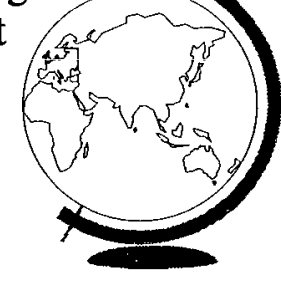

\section{George Barna cont.}

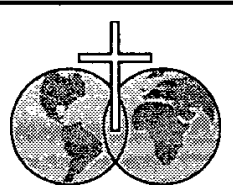

The best way to get the unchurched or nonbelievers to consider the church valid and worthwhile is by making ourselves relevant to their lives. We must understand and respond to their most pressing felt needs.

Most of all, we must show nonbelievers what it looks like to be at peace with ourselves, and to truly love other people.

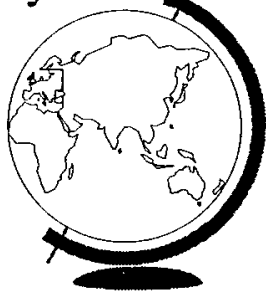




\section{George Barna cont.}

Survey data shows that most Americans believe that you cannot tell a born-again Christian from nonbelievers because there is no difference in the way they live. The only distinction, people say, is that Christians are more religious, more fanatical or more close-minded.

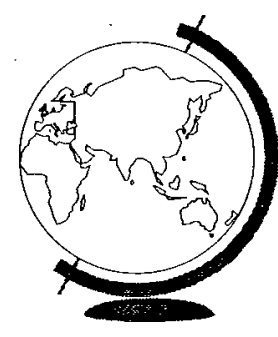

\section{William Easum}

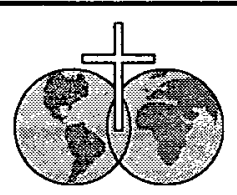

Describe the parable of the lady who owned the finest winery in all the land.

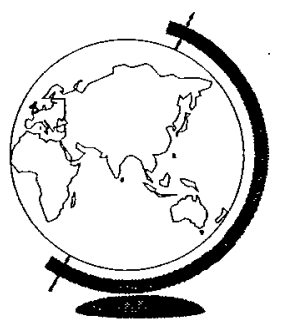




\section{William Easum}

The wineskin (see Matt. 9:17ff) is the church.

For two centuries North American congregations swiftly and efficiently spread the good news across this vast continent offering the grace of God to every part of North America. Today, many of these congregations are becoming irrelevant to a hurting unchurched world and are unable to offer new wine to the new generation.
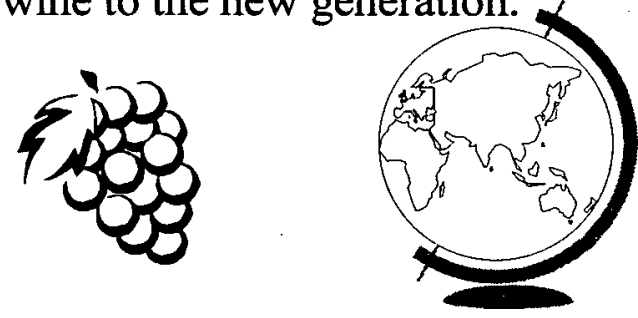

\section{William Easum}

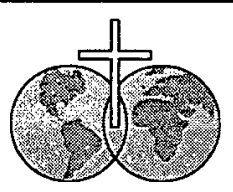

This parable announces a warning to churches that look to the past and ignore the transitional signs all around them. God is calling us to find new ways to apply the good news to a new emerging world. Our churches often fail to quench the thirst of a spiritually dehydrated world. Churches with a slow pace of change are no longer adequate in a fast-changing world.

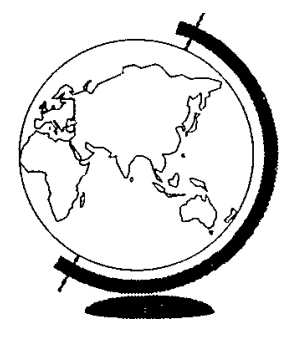




\section{William Easum}

Ministries that worked in the industrial society no longer meet the spiritual needs of people in an informational society. In an age of computers, we cannot express truth in the language of a chariot age. The time has come for new wineskins.
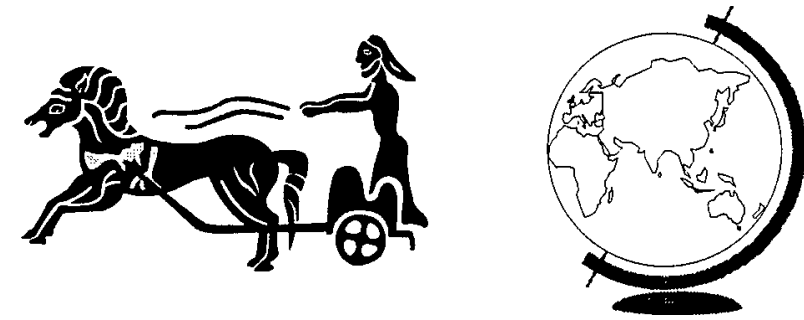

\section{William Easum cont.}

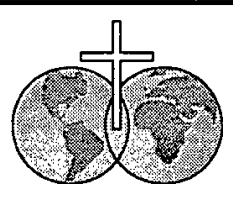

Easum does not want to change the substance of the gospel; merely its packaging. A few adjustments will not suffice. If we continue with our irrelevant packaging, the church will, in time, grow extinct.

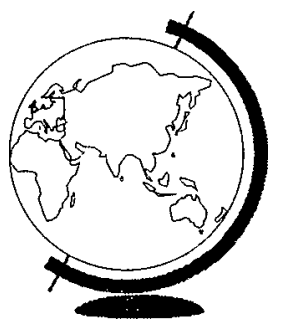




\section{William Easum cont.}

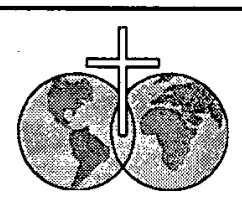

We must stop refusing to change our methods and structures, start ministering to people where they are in ways they can understand. The fastest way to fail is to continually improve on yesterday's successes.

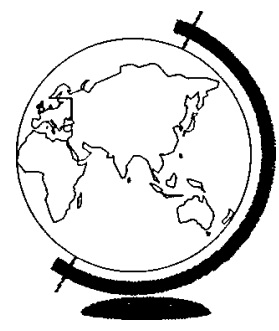

\section{William Easum cont.}

Small-group ministries are replacing programs. Congregations who use them will healthy, others will die out. This transition from program-based to small-group based ministry is the most fundamental paradigm shift in the history of North American Christianity.

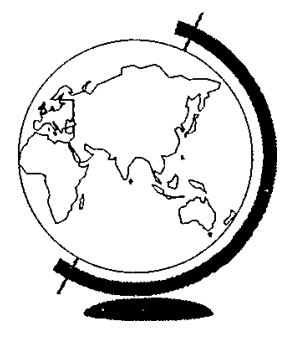




\section{William Easum cont.}

Small groups perform almost all of the traditional roles played by the pastor in the program-based model: counseling, evangelism, and new member assimilation.

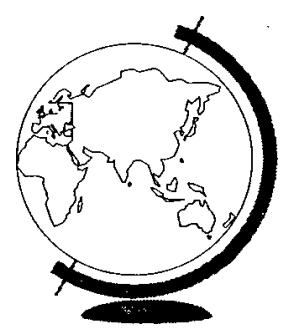

\section{William Easum cont.}

Effective worship is culturally relevant, it grows out of the culture of the area. The style and form is comfortable to those attending worship from the non-Christian world. The message remains the same, but the packaging is culturally relevant.

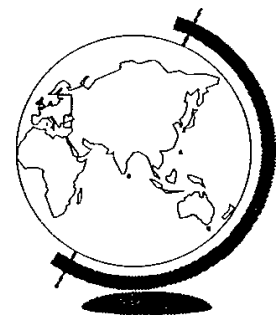




\section{William Easum cont.

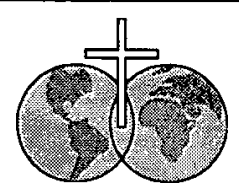

Music is the major vehicle for celebration and communication; it is the vehicle through which most unchurched people experience worship. The type of music that reaches people comes out of their culture. Soft rock is the music of the majority of unchurched people in America. Only four percent of the records sold in the U.S. are classical. It is the ritual of our time, the vehicle or conduit through which the message is conveyed. It is not unusual for music to comprise $40 \%$ of worship in culturally-relevant churches.

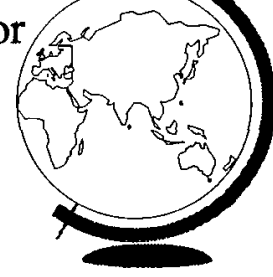

\section{William Easum cont.}

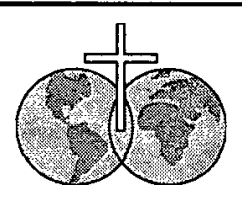

Spiritual giants such as Martin Luther and Charles Wesley showed us the importance of culturally relevant music. They met the needs of the culture of their day by taking the tunes out of bars, putting words to them, and using the songs in worship. They accommodated the needs of people in order to reach them with the message that would eventually change their lives. They did not conform the message, just the package.

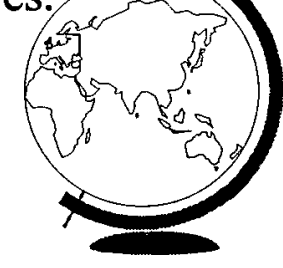




\section{William Easum cont.}

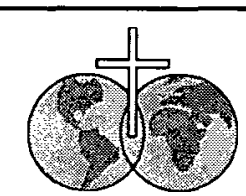

Hymnals are often discarded or supplemented with praise choruses that reflect contemporary tastes in music. The words to the songs are displayed on a large, elevated screen. People look up and around instead of burying their faces in a hymnal or looking down at their feet.

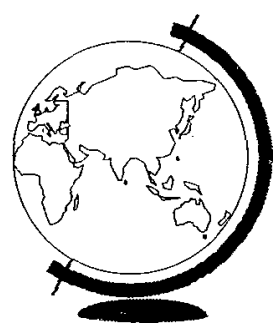

\section{William Easum cont.}

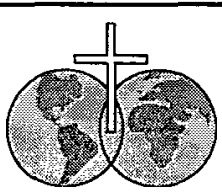

One study of Southern Baptist churches revealed that the quality of the contemporary music is one of the strongest factors in church growth, regardless of size.

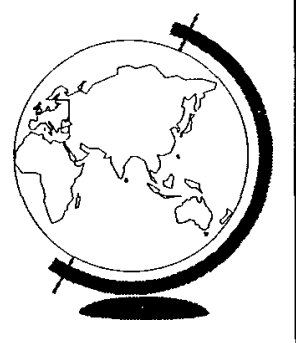




\section{William Easum cont.}

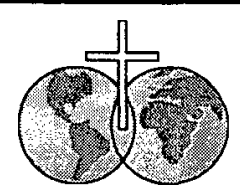

Changing music habits of declining or stagnant congregations is proving to be a major source of conflict. Two styles of worship are needed in churches that have reached their plateaus or are declining. Aged congregations will not give up their style of worship, younger generations do not enjoy worship in the culture of the older generation.

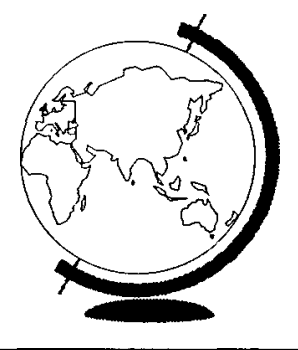

\section{William Easum cont.}

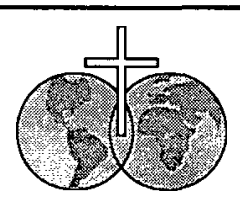

Entertainment is an integral part of contemporary evangelism. Music and drama are a major form of reaching out to the unchurched. Effective preaching makes a passionate appeal to the emotions more than fact, painting a visual picture of the subject.

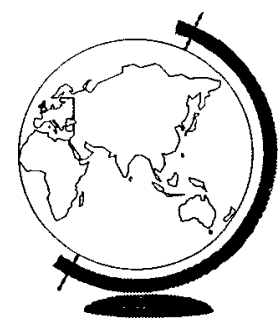




\section{William Easum cont.}

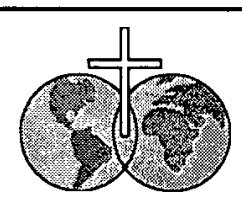

Weekday ministries overshadow the importance of Sunday. In fact, more people participate during the week than on Sunday. The social needs of Christians are being fulfilled within the Christian community. Single adults will be the largest weekday mission field in the twenty-first century.

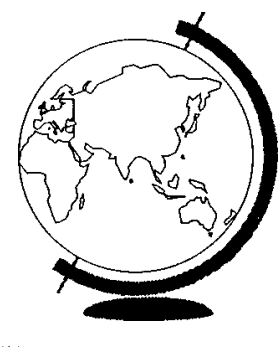

\section{William Easum cont.}

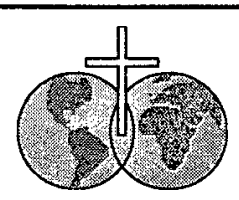

Weekday Bible studies and retreats are reducing the prominence of Sunday schools. Between 1970 and 1990, Sunday school participation in mainline denominations declined by $55 \%$. People today demand a seven-day-a-week community of faith. In time Sunday school may disappear.

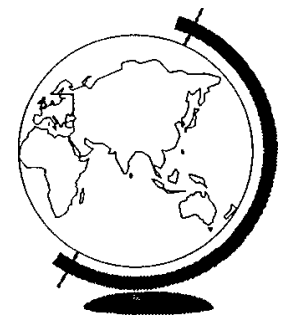




\section{William Easum cont.}

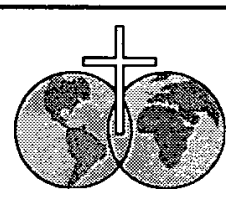

In short, the critical difference between healthy, growing congregations and other churches is not some secret formula for success. Their distinguishing feature is that they do the common, mundane, boring tasks of ministry uncommonly well. They do so regardless of their size, socioeconomic makeup, location, or environmental changes.

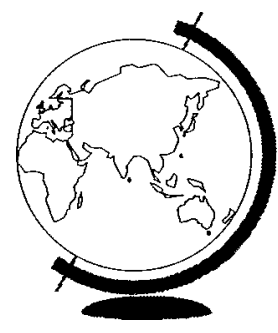

\section{William Easum cont.}

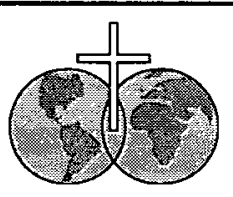

This passion for excellence starts with the role modeling of pastors. It is the basic ingredient to their vision.

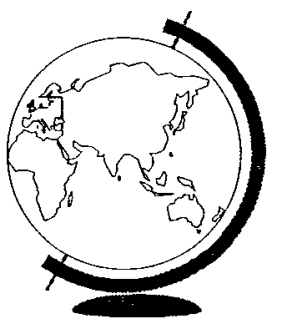




\section{William Easum cont.}

$\$$ We must study sociology more than theology. We must learn how people think and feel and how systems operate.

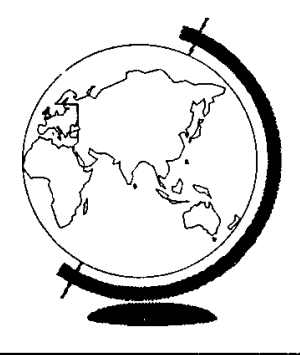

\section{William Easum cont.}

In his book "Sacred Cows Make Gourmet Burgers," Easum lists several characteristics of the sacred cow (immune from criticism) of control:

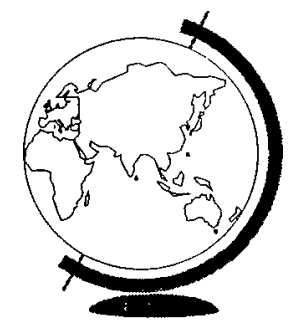




\section{William Easum's "Sacred Cow"}

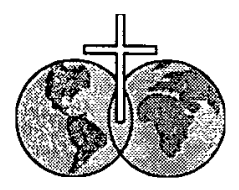

1. "We've never done it that way before."

2. "We tried that before and it didn't work."

3. "No one does THAT in this church."

4. "We do not do things that way."

5. "It's too radical a change for us."

6. "If only it were that easy."

7. "When you've been around longer, you'll understand why it cannot be done."

8. "How dare you criticize what we're doing."

9. "We've been running this church since long before you were born."

\section{William Easum's- "Sacred Cow"}

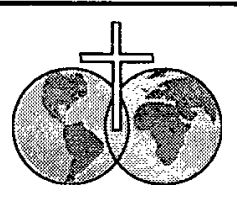

10. "Who gave you permission to change the rules?"

11. "What you're suggesting is against our policies."

12. "Our church law will not let us do that."

13. "Will not that open us up to liability?"

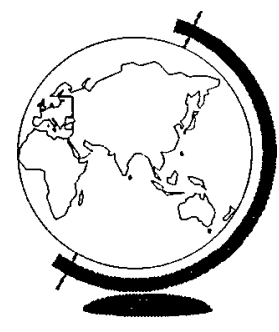




\section{William Easum's- "Sacred Cow"}
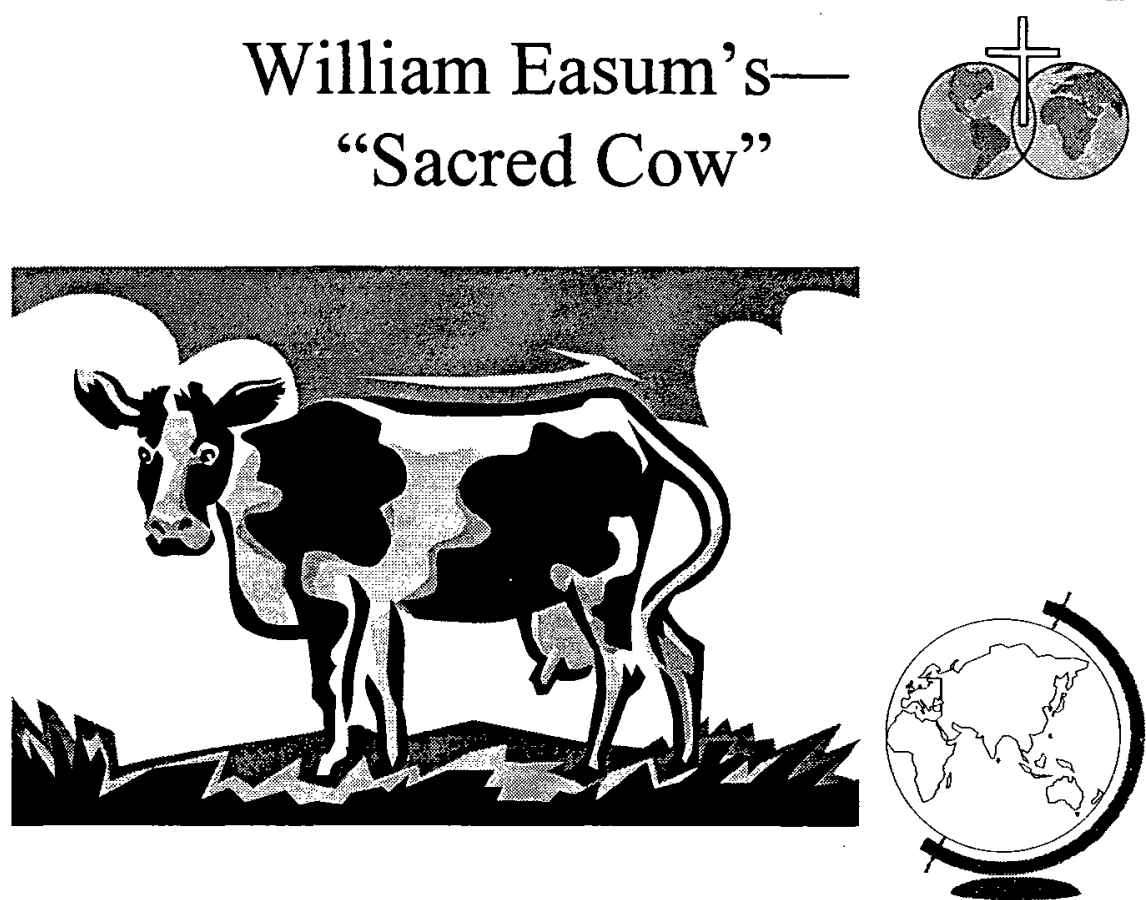

\section{William Easum cont.}

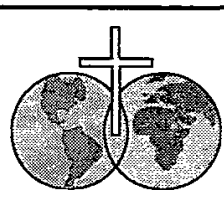

He describes a church that had a yo-yo worship attendance. The membership's average age was sixty, the average age in the community was thirty-five. He suggests the solution is to add a second worship service designed to reach unchurched people between thirty and forty years of age.

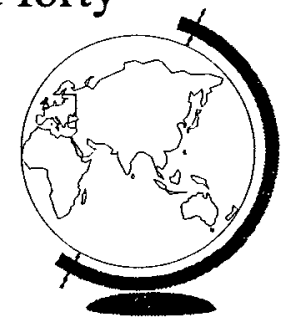




\section{William Easum cont.}

- Yes, "control" is the Sacred Cow of established churches, and it needs to be ground into gourmet hamburger.

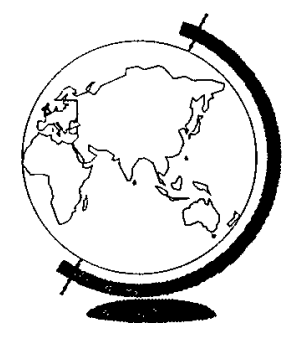

\section{William Easum cont.}

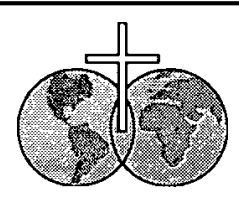

Instead of encouraging churches to gradually change an existing service, he encourages them to begin an alternate service designed for people born after World War Two. Thus, no changes have to be made in the existing service, producing a "win-win" situation.

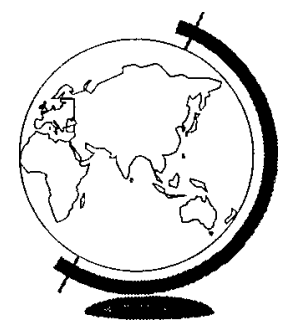




\section{William Easum cont.}

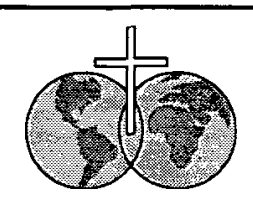

- People born after 1950 are creating a new way of organizing through their emphasis on relationships and computers. Churches that want to reach them must design organizations that emphasize relationships and networks instead of a chain of command.

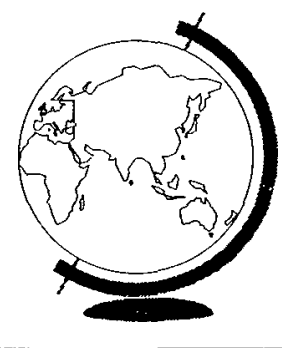

\section{William Easum cont.}

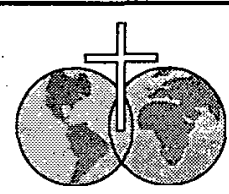

- The more intent a church or denomination is on reaching the unchurched in the twenty-first century the more it will abandon bureaucracy in search of a new method or organizing for ministry.

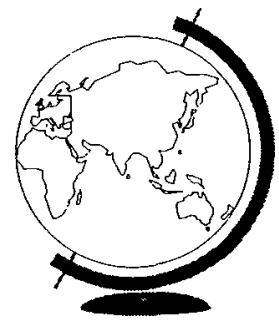




\section{Our Marching Orders...}

$\rightarrow$ Go

Everywhere

Invite everybody
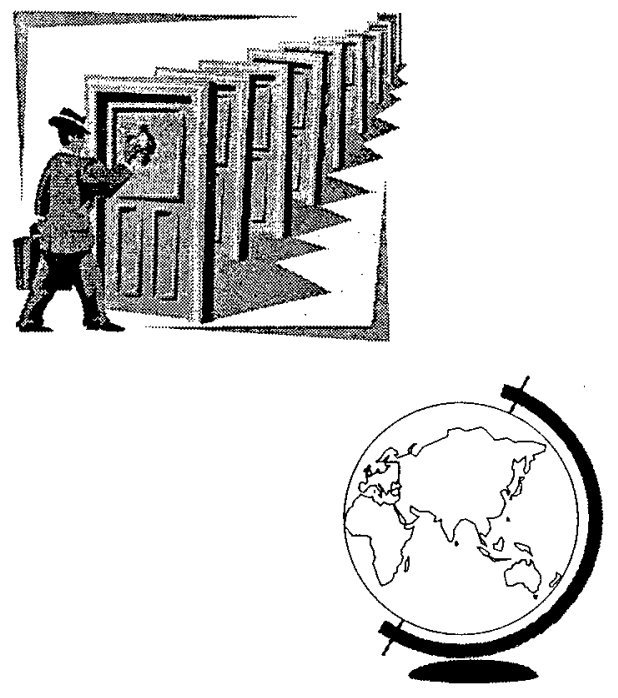

Acts 15:15-18 (NASB) ${ }^{15}$ "With this the words of the Prophets agree, just as it is written, ${ }^{16}$ After these things I will return, And I will rebuild the tabernacle of David which has fallen, And I will rebuild its ruins, And I will restore it, ${ }^{17}$ So that the rest of mankind may seek the Lord, And all the Gentiles who are called by my name,' ${ }^{18}$ Says the Lord, who makes these things known from long ago.
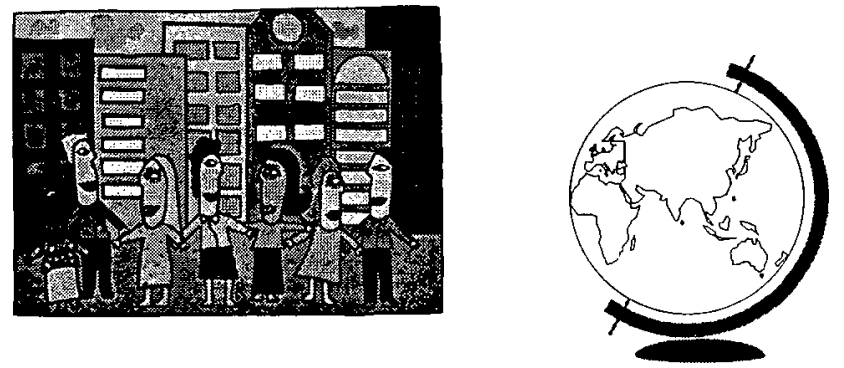
Isa. 56:7 (NASB) ${ }^{7}$ Even those I will bring to My holy mountain and make them joyful in My house of prayer. Their burnt offerings and their sacrifices will be acceptable on My altar; for My house will be called a house of prayer for all the peoples."
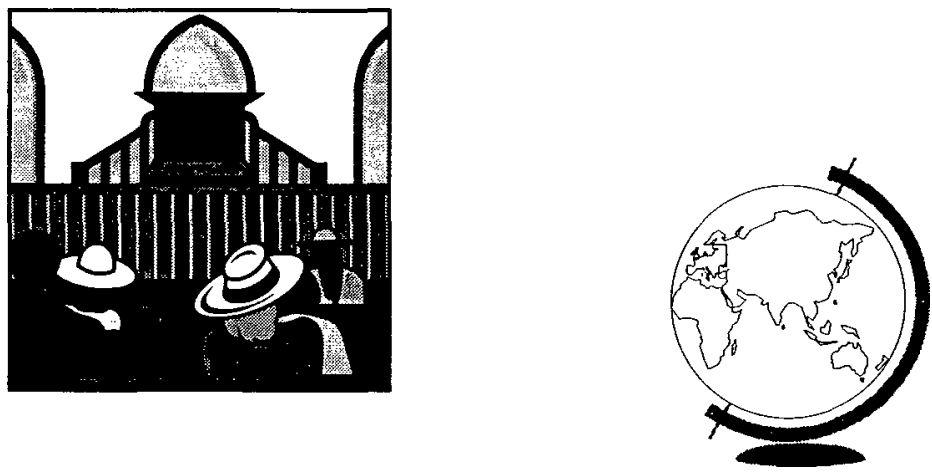

Matt. 24:14 (NASB) ${ }^{14 "}$ This gospel of the kingdom shall be preached in the whole world as a testimony to all the nations, and then the end will come.
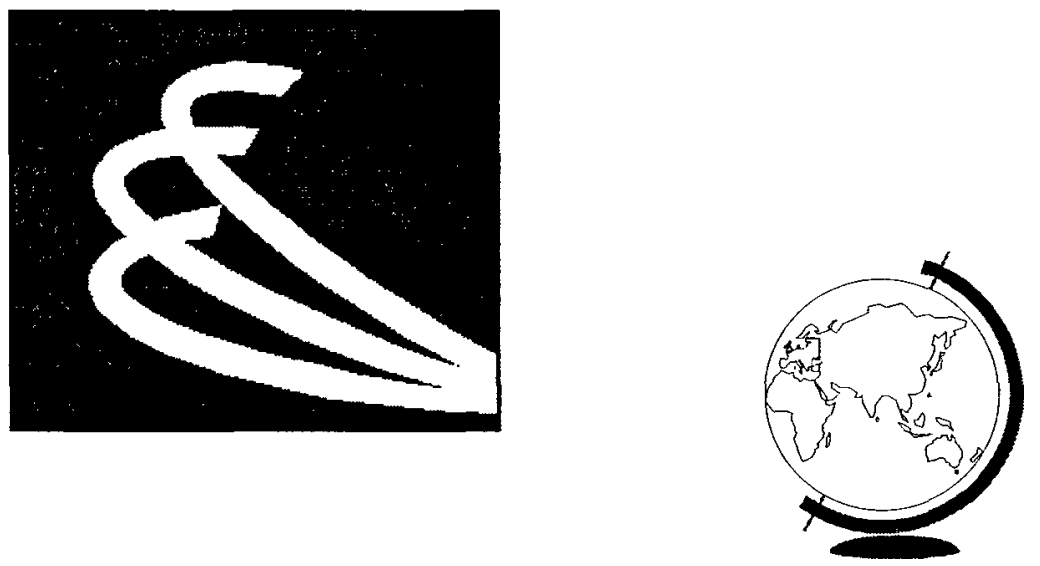
Matt. 28:19 (NASB) ${ }^{19 "}$ "Go therefore and make disciples of all the nations, baptizing them in the name of the Father and the Son and the Holy Spirit,
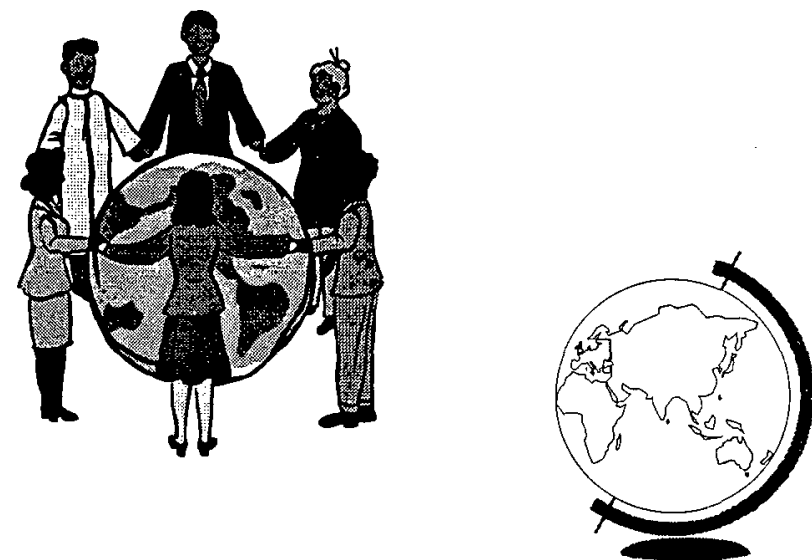

Mark 16:15 (NASB) ${ }^{15}$ And He said to them, "Go into all the world and preach the gospel to all creation.
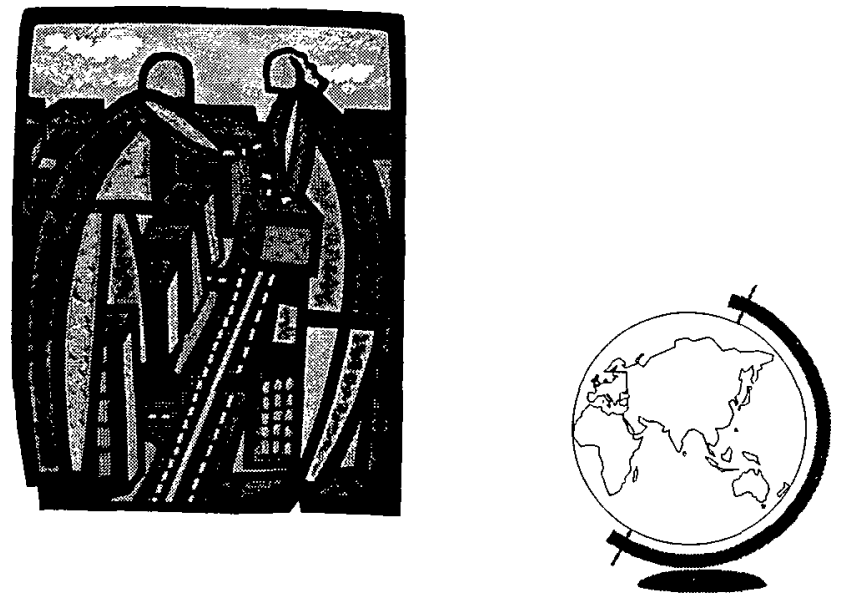
Acts 1:8 (NASB) ${ }^{8}$ but you will receive power when the Holy Spirit has come upon you; and you shall be My witnesses both in Jerusalem, and in all Judea and Samaria, and even to the remotest part of the earth."
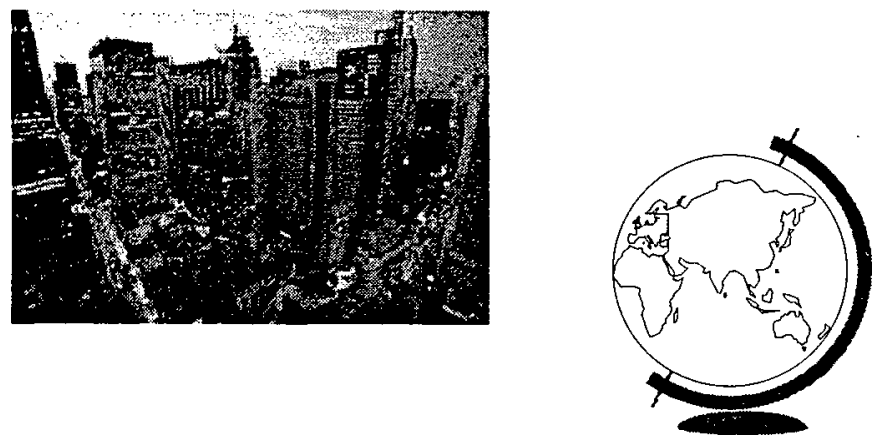

Acts 2:47 (NASB) ${ }^{47}$ praising God and having favor with all the people. And the Lord was adding to their number day by day those who were being saved.
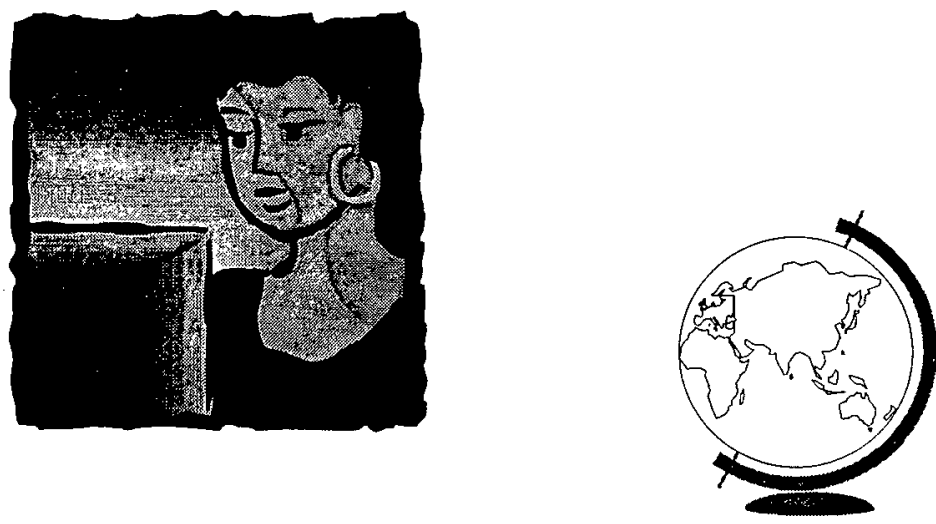
John 10:16 (NASB) ${ }^{16 " I ~ h a v e ~ o t h e r ~ s h e e p, ~ w h i c h ~ a r e ~}$ not of this fold; I must bring them also, and they will hear My voice; and they will become one flock with one shepherd.
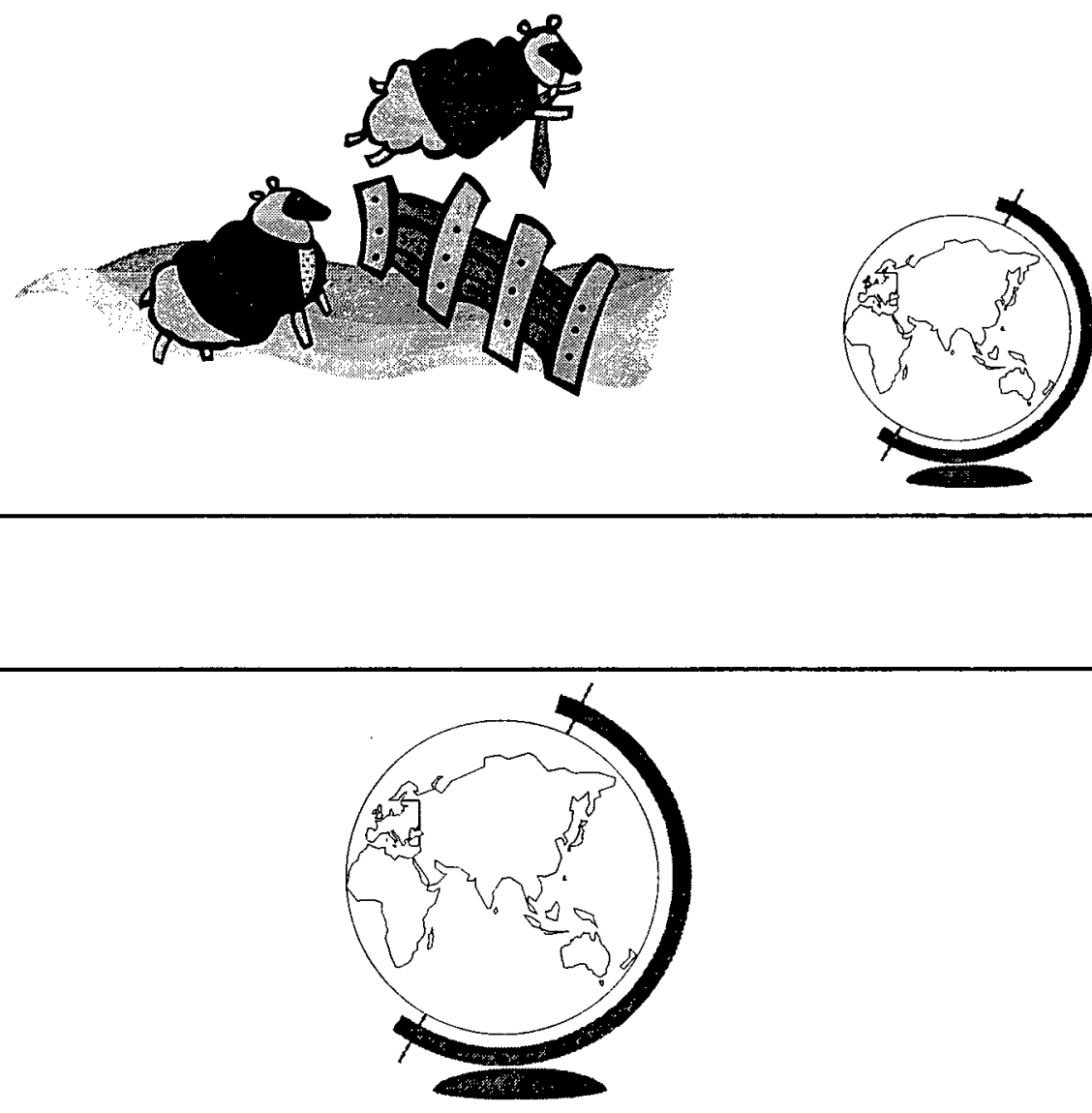

The Rest of Mankind

Reaching the $21^{\text {st }}$ century secular mind 
BIBLIOGRAPHY 


\section{BIBLIOGRAPHY}

Adams, Roy. "Come, Holy Spirit, Renew the Whole Creation-Report from the Seventh Assembly of the World Council of Churches, Canberra, Australia, 1991." Adventist Review, 11 April 1991, 8-10.

Allaback, Fred. "The Celebration Church." Liberty Review, Spring 1990, 22-25.

Allen, Martha Sawyer, and Graydon Royce. "A Rock-and-Bill Night at the Dome." Star Tribune, 23 June 1993, A1.

Allen, Ronald B., and Gordon Borror. Worship: Rediscovering the Missing Jewel. Portland, OR: Multnomah Press, 1982.

American Heritage Dictionary of the English Language. $3 d$ ed. 1992. S.v. "Secularism."

Anderson, Leith. A Church for the $21^{\text {st }}$ Century. Minneapolis: Bethany House, 1992. 1990 .

- Dying for Change. Minneapolis: Bethany House Pub.,

Anderson, Lynn. Navigating the Winds of Change. West Monroe: Howard Publishing Co., 1994.

Anderson, Roy Allen. Editorial. Ministry, September 1932,

19. Quoted in John W. Fowler, Evangelism 2000. Boise: Pacific Press, 1994.

Anderson, R. A. "Effective Worship." Ministry, September 1964,48 .

46.

. "The Supremacy of Worship." Ministry, July 1957,

. "True Worship." Ministry, June 1951, 11-13. 
[Anonymous], Leona and Eugene. "To Dear Friends at Prophecy Countdown." In Celebration or Abomination, ed. John Osborne, vi. Mt. Dora, FL: Prophecy Countdown, 1990.

Appleby, David P. History of Church Music. Chicago: Moody Press, 1965.

Arakaki, Lyle M. "Functioning as the Family of God." Ministry, February 1998, 16-17.

Bailey, Robert $\mathbf{w}$. New Ways in Christian Music. Nashville: Broadman, 1981.

Baker, Delbert W., ed. Make Us one: Celebrating Spiritual Unity in the Midst of Cultural Diversity. Boise, ID: Pacific Press, 1995.

Baker, Paul. Contemporary Christian Music: Where It Came From, what It Is, Where It's Going. Westchester, IL: Crossway Books, 1985.

- Why Should the Devil Have All the Good Music? Waco, TX: Word Books, 1979 .

Baldwin, Jennifer. "Wahroonga Launches Worship Initiative." South Pacific Division Record, 25 May 1991, 13.

Baptiste, Harold W. "Back to the Business of the Church." Adventist Review, 4 March 1993, 5.

Barna, George. The Frog in the Kettle: What Christians Need to know about Life in the Year 2000. Ventura: Regal Books, 1990 .

- The Power of Vision: How You Can Capture and Apply God's Vision for Your Ministry. Ventura, CA: Regal Books, 1992 .

- Turn-Around Churches: How to Overcome Barriers to Growth and Bring New Life to an Established Church. Ventura: Regal Books, 1993.

- User Friendly Churches: What Christians Need to Know About the Churches People Love to Go To. Ventura: Regal Books, 1991.

- What Americans Believe: An Annual Survey of Values and Religious Views in the United States. Ventura, CA: Regal Books, 1991. 
Barth, Karl. Worship: Its Theology and Practice. London: Lutterworth, 1965.

Beach, Bert B. "Adventism and Secularization." Ministry, April 1996, 22-25.

Beckham, William A. The Second Reformation: Reshaping the Church for the Twenty-first Century. Houston, TX: Touch Publications, 1995.

Berger, Peter I. The Sacred Canopy: The Social Reality of Religion. Harmondsworth: Penguin Books, 1973.

Bietz, Gordon. "Whatever Happened to Reverence?" Adventist Review, 8 November 1990, 8, 9.

Birch, Alf. "What Is Worship?" South Pacific Division Record, 1 June 1991, 4-7.

Bird, Warren. "The Great Smal1-Group Takeover." Christianity Today, 7 February 1994, 25-29.

Blake, Christopher. "The Youth Challenge: Why Revival Isn't Enough-2." Adventist Review, 16 August 1990, 8-10.

Boze, Michael, ed. "Celebrating Community." Willow Creek 2 (November/December 1990): 12-39.

Brady, Diane. "Saving the Boomers: Churches Shun Tradition to Attract Young Adults." Maclean's, 3 June 1991, 5051.

Brewer, W. Eugene. "Must Great Minds Worship Alike?" Adventist Review, 30 October 1997, 14-17.

Brown, Gina Spivey, and Loretta Parker Spivey. "A Few Words About Praise." Adventist Review, November 1997, 27.

Brown, Paul B. In and For the World: Bringing the Contemporary into Christian Worship. Minneapolis: Fortress Press, 1992.

Bruinsma, Reinder. "Contextualizing the Gospel--Option or Imperative?" Ministry, December 1997, 14-16.

Bryan, Alex. "The Local Church Is the Church. Period." Adventist Review, 19 March 1998, 8-10.

Campolo, Anthony. A Reasonable Faith: Responding to Secularism. Waco: Word Books, 1993. 
- "The Spirit Hasn't Left Mainline." Christianity Today, 11 August 1997, 14.

Case, Steve. "Music to His Ears." Adventist Review, 30 October 1997, 59-62.

"Celebration Church Tractbook." Manuscript. Adventist Heritage Center, James White Library, Andrews University, Berrien Springs, MI.

Celente, Gerald. Trend Tracking. New York: John Wiley \& Sons, 1990.

Chandler, Russell, ed. Racing Toward 2001: The Forces Shaping America's Religious Euture. San Francisco: Harper \& Row, 1992.

Church Ministries Department. Creative Sabbath Morning Alternatives: Revitalizing Sabbath School and Church. Westlake, CA: Pacific Union Conference of Seventh-day Adventists, 1991.

Clapp, Rodney. "The Sin of Winnie-the-Pooh." Christianity Today, 9 November 1992, 29-32.

Colson, Charles. "Welcome to McChurch: Consumerism and Religion." Christianity Today, 23 November 1992, 28-32.

Comstock, Darryl. "Selling Change." Ministry, October 1991, $30,31,39$.

- Selling the Celebration Church: The Holy spirit, Eorms of Worship, and Church Unity. Adventist Heritage Center, Andrews University, Berrien Springs, MI.

Cook, Jerry, and Stanley C. Baldwin. Love, Acceptance \& Eorgiveness: Equipping the Church to Be Truly Christian in a Non-Christian World. Ventura, CA: Regal Books, 1979 .

"Covering Religion: Interview with Television Journalist Walter Cronkite." The Christian Century, 14 December $1994,1200-1202$.

Cox, Kenneth 0 . "Evangelistic Problems and Suggestions." In Meeting the Secular Mind: Some Adventist Perspectives, ed. Humberto M. Rasi and Fritz Guy, 80. Berrien Springs, MI: Andrews University Press, 1985. 
Crews, Joe. "Consecration or Desecration?" Current Questions, January 1991, 3-5, 16.

- "Consecration or Desecration?" Inside Report 9 (January 1991): 4.

Cress, James A. "Worship Is a Verb." Ministry, June 1995, 29-30.

Crichton, J. D., ed. The Liturgy and the Future. Techny, IL: Divine Word Publications, 1966.

Daily, Steve. "Church Growth Bloweth Where It Listeth." Spectrum 19 (February 1989): 2-4.

. "Old Torch, New Fire." Adventist Today, May/June $1995,11,12$.

Day, Dan. A Guide to Marketing Adventism. Boise: Pacific Press, 1990.

Dawson, John. Taking Our Cities for God. Lake Mary, FL: Creation House, 198

Dederen, Raoul. "Charismatics and Catholics." Ministry, May 1976, 17-19.

- "Crisis and Promise in the Consultation on Church Union." These Times 148 (January 1972): 21-24.

- "Faith and Order Commission." Review and Herald, 2 December 1971, 4-6.

1978, 24B-F.

- "The Present State of Ecumenism." Ministry,

September 1975, 12-14.

de Ojeda, Anita J. Strawn. "Sing the Song of Gladness." Ministry, September 1996, 5, 6, 29.

"Devotion or Deception? Revival and Reformation."

Manuscript. Adventist Heritage Center, James White

Library, Andrews University, Berrien Springs, MI.

Dobson, Ed. Starting a Seeker Sensitive Service: How Traditional Churches Can Reach the Unchurched. Grand Rapids: Zondervan, 1993. 
Dolan, Barbara. "Full House at Willow Creek; a Multimedia Appeal to the 'Unchurched Harrys'." Time, 6 March 1989, 60 .

Dossman, Craig A. "Don't Forget the Bridge." Ministry, October 1991, 24-26.

Doukhan, Lillianne. "Historical Perspectives on Change in Worship Music." Ministry, September 1996, 7-9.

Duerksen, Richard. "Abrazando Mucho." Adventist Review, 30 October 1997, 6-7.

. "Let's Warm Up Worship!" Columbia Union Visitor, 15 February 1992, 2.

Dudley, Roger I. Valuegenesis: Faith in the Balance. Riverside, CA: La Sierra University Press, 1992.

Dybdahl, Jon. "Cross-Cultural Adaptation." Ministry, November 1992, 14-17.

Dyrness, William A. How Does America Hear the Gospel? Grand Rapids, MI: Eerdmans, 1989.

Easum, William. Dancing With Dinosaurs: Ministry in a Hostile and Hurting World. Nashville: Abingdon Press, 1993. 1991 .

- How to Reach Baby Boomers. Nashville: Abingdon,

- Sacred Cows Make Gourmet Burgers: Ministry Anytime, Anywhere, By Anyone. Nashville: Abingdon Press, 1995.

Edwards, Rex D. "Threats to Worship." Ministry, October $1991,5$.

Ellsworth, Donald P. Christian Music in Contemporary Witness. Grand Rapids: Baker, 1979.

Encyclopedia Britannica. 1998 ed. S.v. "Humanism."

Engel, James F. Contemporary Christian Communications, Its Theory and Practice. Nashville: Thomas Nelson, 1979.

Eva, Will. "Worship and Music: Natural But Uneasy Mates." Ministry, September 1996, 4, 28. 
Fagal, William. "The War Over Worship." Adventists Affirm, Fall 1991, 3, 4.

Ferrell, Vance. "Counsels on the Celebration Church." Pilgrim's Rest Tract, PG 211-212, n.d., 1-8, newsletter.

- "The Fastest Growing Movement in American Adventism Today-Multiplying the Celebration Churches." Pilgrim's Rest Tract, WM 270-274, n.d., 1-20, newsletter.

- "Inroads of the Celebration Church-April 1990." Pilgrim's Rest Tract, WM 277-278, n.d., 1-12, newsletter.

- "Multiplying the Celebration Church." Pilgrim's Rest Tract, WM 309-312, n.d., 1-12, newsletter.

- "North American Division: Getting Rid of the Standards." Pilgrim's Rest Tract, WM 287, n.d., 4, newsletter.

- "Our Local Church Crisis-Local Conferences: Switching Over to Pentecostalism." Pilgrim's Rest Tract, WM 287, n.d., 1, newsletter.

- "The Plague of Pentecostalism Has Finally Arrived-The Celebration Church." Pilgrim's Rest Tract, WM 254, 21, 22, newsletter.

- "A Visit to a Celebration Church." Pilgrim's Rest Tract, WM 314, n.d., 1-4, newsletter.

Fenn, Richard K. Liturgies and Trials: The Secularization of Religious Lanquage. Oxford: Basil Blackwell, 1982.

Finley, Mark. "Target and Tactics." In Meeting the Secular Mind: Some Adventist Perspectives, ed. H. Rasi and Fritz Guy, 101-102. Berrien Springs, MI: Andrews University Press, 1985.

Folkenberg, Robert S. "Why Secularism Attracts Christians, Part 1." Adventist Review, July 1997, 29.

- "Why Secularism Attracts Christians, Part 2." Adventist Review, August 1997, 19.

Fowler, John M. "O Come, Let Us Worship!" Ministry, October 1991, 6-9. 
Fowler, John w. Evangelism 2000: Proclaiming Christ in the $21^{\text {st }}$ Century. Boise: Pacific Press, 1994.

Frame, Randy. "Principle or Pragmatism? Christian Activists Torn Between Compromise and Stance." Christianity Today, 13 November 1995, 70-72.

Frazier, Eric, "Baptists: A Denomination in Transition." Post and Courier, 20 April 1997, D9.

Frazier, Franklin. The Negro Church in America. New York: Schocken Books, 1964.

Fredericks, Richard. "To Celebrate or Not to Celebrate!" Ministry, August 1992, 7-10.

Galloway, Dale E. 20/20 Vision: How to Create a successful Church. Portland, OR: Scott Publishing Co., 1986.

Gang, Jeffrey. "Worship for Young Adults: A New Paradigm." M.Div. research paper, Seventh-day Adventist Theological Seminary, March 1995.

Gelder, Craig Van. "Defining the Center-Finding the Boundaries: The Challenge of Re-Visioning the Church in North America for the Twenty-First Century."

Missiology: An International Review (July 1994): 317337.

Gang, Jeffrey. "Worship for Young Adults: A New Paradigm." M.Div. research paper, Seventh-day Adventist Theological Seminary, March 1995.

George, Carl F. "Challenges Facing Adventists." Adventist Review, 5 January 1989, 17-19.

- Empty Pews, Empty Streets. Columbia, MD: Columbia Union Conference of Seventh-day Adventists, 1988.

- Prepare Your Church for the Future. Grand Rapids: Fleming Revell, 1992.

- "A Tilt Toward the Relational." Christianity Today 17 (January 1986): 22, 23-I.

Gill, Robin. The Social Context of Theology: A Methodological Enguiry. London: Mowbrays, 1975.

Giller, Eoin. "Church Alive." Syllabus prepared for 1990 World Ministers Council, Indianapolis, IN, 1 July 1990. 
- "Worship Renewal in the Seventh-day Adventist

Church." Ministry, October 1991, 16-19.

Gillespie, V. Bailey. "An Adapted Task Force Report on

Faith, Values, and Commitment." Adventist Review, 10 January 1991, 17, 18 .

- "Nurturing Our Next Generation." Adventist Review, 3 January 1991, 5-11.

- "Valuegenesis Report Offers Important

Information." Pacific Union Recorder, 3 December 1990, 10,11 .

Goode, Stephen. "Baby Busters Rediscover God." Insight on the News, 5 June 1995, 12-13.

Graybill, Ronald D. "Enthusiasm in Early Adventist Worship." Ministry, October 1991, 10-12.

Grolier Encyclopedia. 1998 ed. S.v. "Humanism."

Gustafson, Christine. "Robert Schuller's Crystal Empire." The Metropolital Journal, 15 July 1990, 9-11.

Gustafson, Gerrit. Advanced Worship Seminar Manual. Sylmar, $\mathrm{CA}$ : Worship Seminars International, 1991.

"Hackettstown Turns Church Upside Down for Sabbath School." Columbia Union Visitor, 15 March 1989, 5.

Hamel, Paul. The Christian and His Music. Washington, DC: Review \& Herald, 1973.

- Ellen White and Music: Background and Principles. Washington, DC: Review \& Herald, 1976.

Hatch, Nathan 0 . The Democratization of American Christianity. New Haven, CT: Yale University Press, . 1989 .

Hauerwas, Stanley. After Christendom? How the Church Is to Behave if Freedom, Justice, and a Christian Nation Are Bad Ideas. Nashville: Abingdon Press, 1991.

Hauerwas, Stanley, and William H. Willimon. Resident Aliens: Life in the Christian Colony. Nashville: Abingdon Press, 1989. 
Heise, Lyell V. "Music and Worship." Ministry, October 1991, 20-24.

"The Hemispheric Nature of the Brain." Education Town Hall Meeting October 26, 1995, at the Florida Conference of Seventh-day Adventists. In my possession.

Herber, A.G. Lituray and Society: The Function of the Church in the Modern World. London: Faber, 1961.

Hofstadter, Richard. Anti-Intellectualism in American Life. New York: Vintage, 1963.

Holmes, C. Raymond. "Authentic Adventist Worship." Ministry, October 1991, 13-16.

- Sing a New Song. Berrien Springs, MI: Andrews University Press, 1984.

Horn, Henry E. Worship in Crisis. Philadelphia: Fortress Press, 1972 .

Horton, Michael Scott. Made in America: The Shaping of Modern Evangelicalism. Grand Rapids, MI: Baker, 1991.

Howard, Thomas. Evangelical Is Not Enough. Nashville: Nelson, 1984.

Hunter, George G., III. Church for the Unchurched. Nashville: Abingdon Press, 1996.

- How to Reach Secular People. Nashville: Abingdon Press, 1992.

Hunter, James D. American Evangelicalism: Conservative Religion and the Quandary of Modernity. New Brunswick: Rutgers University Press, 1983.

Hybels, Bill. Christians in the Marketplace. Wheaton, IL: Victor Books, 1982.

- Honest to God? Becoming an Authentic Christian. Grand Rapids, MI: Zondervan, 1990.

- Seven Wonders of the Spiritual World. Dallas, TX. Word Books, 1988.

- Too Busy Not to Pray. Downers Grove, IL: Intervarsity Press, 1989. 
Hybels, Bill, Stuart Briscoe, and Haddon Robinson. Mastering Contemporary Preaching. Portland, OR: Multnomah Press, 1989 .

Hybels, Lynn, and Bill Hybels. Rediscovering Church. Grand Rapids: Zondervan Press, 1995.

Johnson, Noelene. "God's Pictures." Adventist Review, November 1997, 8-10.

Johnson, William G. "Awash in a Sea of Relativism." Adventist Review, August 1997, 5.

- The Fragmenting of Adventism. Boise, ID: Pacific Press, 1995.

- "When the Family Splits." Adventist Review, November 1997, 16-19.

. "When We All Get Together." Adventist Review, 30 October 1997, 12.

Jones, Landon. Great Expectations: America and the Baby Boom Generation. New York: Ballantine Books, 1986.

Juberg, Morton. "Worship Conference Features New Ideas." Adventist Review, 20 June 1991, 21-22.

Kaiser, Christopher. Creation and the History of Science. Grand Rapids: Eerdmans, 1991.

Kendrick, Graham. Learning to Worship as a Way of Life. Minneapolis: Bethany House, 1984.

Kerr, Ruthie. "Living to Worship in Atlanta." Adventist Review, 20 February 1997, 13.

Ketting, Ginger. "Crossways." Adventist Review, 20 February $1997,8-10$.

Klaas, Alan C. In Search of the Unchurched. Why Don't People Join Your Congregation. Bethesda, MD: Alban Institute, 1996.

Kraft, Charles H. Communication Theory for Christian Witness. Maryknoll, NY: Orbis Books, 1991.

Krause, Gary. "In Spirit and Truth." Adventist Review, 30 October 1997, 74-75. 
Kuzma, Kay. "Worship--A Celebration of Love for Children." Adventist Review, 17 March 1983, 9-10.

Larson, Bob. Rock. Wheaton, IL: Tyndale House, 1980. - Rock and the Church. Carol Stream, IL: Creation House, 1971.

LaRue, John C. "The Contemporizing of Worship Music." Computing Today, July/August 1997, 72.

Lawhead, Steve. Rock Reconsidered. Downers Grove, IL: InterVarsity Press, 1981.

Lewis, C.S. Mere Christianity. New York: Macmillan Press, 1960 .

Liesch, Barry Wayne. People in the Presence of God: Models and Directions for Worship. Grand Rapids, MI: Zondervan, 1988 .

Light, Paul C. The Baby Boomers. New York: W. W. Norton \& Co., 1988.

MacArthur, John. "Gimmi That Showtime Religion." Masterpiece (September/October 1990): 2-3.

Mann, Rick. "The Passion and the Power." Adventist Review, 30 October 1997, 4-5.

Manners, Bruce. "Battling the Worship Committee." Ministry, October 1996, 10-12.

Marsden, George M. Fundamentalism and American Culture: The Shaping of Twentieth-Century Evangelicalism: 1870-1925. New York: Oxford University Press, 1980.

Marshall, Rome P., and Michael J. Taylor. Liturgy and Christian Unity. Englewood Cliffs, NJ: Prentice Hall, 1965 .

Martin, Carlos G. "Evangelism in a Non-Christian Culture." Ministry, February 1997, 24-26.

Martin, Dale, and Richard O'Ffill. "Set Free to Worship." Adventist Review, 30 October 1997, 67-71

Martin, David A. A General Theory of Secularization. New York: Harper \& Row, 1978. 
Matthews, Daniel G. "Going Where the People Are: Isn't It Time We Embraced a Broader Ministry Focus?" Adventist Review, 19 August 1999, 8.

. "Reaching the General Television Audience." In Meeting the Secular Mind: Some Adventist Perspectives, ed. Humberto M. Rasi and Fritz Guy, 158. Berrien Springs, MI: Andrews University Press, 1985.

Maudlin, Michael G. "Selling Out the House of God? Bill Hybels Answers Critics of the Seeker-church Movement." Christianity Today, 18 July 1994, 20-25.

Maxwell, C. Mervyn. "Baby Boomers, Celebration Churches, and Moral Leadership." Adventists Affirm 5 (Fall 1991): 535 .

- "Baby Boomers, Celebration Churches, and Moral Leadership." In Pilgrim's Rest Tract, ed. Vance Ferrell, nos. WM 423-424, n.d. 1-8, newsletter.

McClure, A.C. "Remembering the Mission." Adventist Review, 5 March 1992, 5. Quoted in John W. Fowler, Evangelism 2000. Boise: Pacific Press, 1994.

McFague, Sallie. Metaphorical Theology: Models of God in Religious Language. Philadelphia: Fortress Press, 1982.

McFarlane, D. W. "Three Things to Think About." Adventist Review, 11 July 1996, 14-17.

McGrath, Alister. "Why Evangelicalism Is the Future of Protestantism." Christianity Today, 19 June 1995, 1823.

McIntosh, Gary L. "Ten Common Riptides." McIntosh Church Growth Network, July 1995.

McNeil, Page. "We Have a Reason to Celebrate. What About Celebration Churches?" Insight, 23 November 1991, 4-5.

Medley, Carlos. "NAD President Calls for New Growth Strategies." Adventist Review, November 1997, 20.

Mfune, Saustin Sampson. "More than Half a Brain." Ministry, October 1991, 28-30. 
Miller, Steve. The Contemporary Christian Music Debate: Compromise or Agent of Renewal? Wheaton, IL: Tyndale House Pub., 1993.

Moberg, David 0 . The Church as a Social Institution: The Sociology of American Religion. $2^{\text {nd }}$ ed. Grand Rapids, MI: Baker, 1984 .

Moore, A. Leroy Adventism in Conflict: Resolving the Issues That Divide Us. Hagerstown, MD: Review \& Herald, 1995.

Moyer, Bruce Campbell. "Surrounded? Thank God! The Urban Paradox." Adventist Review, 5 June 1998, 12-15.

Murren, Doug. The Baby Boomerang: Catching Baby Boomers as They Return to Church. Ventura: Regal Books, 1990.

- Leadershift: How to Lead Your Church into the $21^{\text {st }}$ Century by Managing Change. Ventura: Regal Books, 1994.

Naisbitt, John. Megatrends: Ten New Directions for Transforming Our Lives. New York: Warner Books, 1982.

Naisbitt, John, and Patricia Aburdene. Megatrends 2000: Ten New Directions for the 1990s. New York: William Morrow and Co., 1990.

Nash, Andy. "On Willow Creek." Adventist Review, 18 December $1997,6$.

- "Riding the Grace Wave." Adventist Review, 30 October 1997, 8-9.

Nash, Michelle. "I'm Not Going to Have Worship Anymore." Adventist Review, 30 October 1997, 22-23.

Newbigin, Lesslie. The Gospel in a Pluralist Society. Grand Rapids: Eerdmans Press, 1990.

Newman, J. David. "The Cross, the Center of Worship." Ministry, October 1991, 4. 1993, 55.

- "Reaching the Secular Mind." Ministry, November

Niebouhr, Ralph. Where Do We Go from Here? Houston, TX: Touch Publications, 1990.

Niebuhr, H. Richard. The Social Sources of

Denominationalism. New York: World Publishing, 1929. 
Norton, Ricardo. Class notes for CHMN664, Training and Motivation of Laity in Ministry. Takoma Park, MD, March 1996.

O'Conner, Bill. "Ten Reasons We Need Those Great Hymns." Ministry, September 1996, 21-22.

O'Dea, Thomas F. Sociology \& the Study of Religion: Theory, Research, Interpretation. New York: Basic Books, 1970.

O'Dea, Thomas F., and Janet O'Dea Aviad. The Sociology of Religion. $2^{\text {nd }}$ ed. Englewood Cliffs, NJ: Prentice Hall, 1983.

Oosterwal, Gottfried. "The Process of Secularization." In Meeting the Secular Mind: Some Adventist Perspectives, ed. Humberto Rasi and Fritz Guy, 45-49. Berrien Springs, MI: Andrews University Press, 1985.

Ostling, Richard N. "The Church Search." Time, 5 April 1993, 44-49.

- "Superchurches and How They Grew: American Protestants Are Turning to One-stop Shopping." Time, 5 August 1991, 62-63.

Panikkar, Raimundo. Worship and Secular Man. New York: Orbis Books, 1973.

Patterson, Gary. "Is Our Upbringing Defining Us?" Adventist Review, 19 September 1996, 24-27. 15 . - "Mission as Worship." Ministry, October 1996, 13- "Possibilities for Creative Preaching and Worship in the Seventh-day Adventist Church." D.Min. project, Divinity School of Vanderbilt University, May 1979.

Patterson, Robert $\mathrm{w}$. "Can Mainline Denominations Make a Comeback?" Christianity Today, 23 October 1995, 70.

Paulien, Jon. "The Gospel in a Secular World." In Meeting the Secular Mind: Some Adventist Perspectives, ed. Humberto Rasi and Fritz Guy, 27. Berrien Springs, MI: Andrews University Press, 1985.

- "Lions and Tigers and Bears." Adventist Review, 15 January 1998, 8-12. 
- Present Truth in the Real World. Boise: Pacific Press, 1993.

Pawluk, Carol. "Paradigms of Worship." Adventist Review, 30 October 1997, 19-21.

Pearson, Michael. Millennial Dreams and Moral Dilemmas: Seventh-day Adventism and Contemporary Ethics. Cambridge, NY: Cambridge University Press, 1990.

Pease, Norval F. And Worship Him. Nashville: Southern Pub. Assn., 1967.

Phillips, Timothy R., and Dennis L. Okholm, eds. Christian Apologetics in the Postmodern World. Downers Grove: Intervarsity Press, 1995.

Pooler, Terry G. Class notes for "Worship and Church Music." D.Min. intensive course, Forest Lake Academy Church, March 1997.

- "Toward a Ministry of Inclusiveness as a Power for Transforming a Church: A Case Study." D.Min. project, Andover Newton Theological School.

Power, David N. Worship, Culture and Theology. Washington, DC: Pastoral Press, 1990.

Preast, Ronald L. "Targeting Your Audience." Ministry, December 1995, 28-30.

Pritchard, G.A. Willow Creek Seeker Services: Evaluating a New Way of Doing Church. Grand Rapids: Baker Books, 1996.

Rasi, Humberto M., and Fritz Guy, eds. Meeting the Secular Mind: Some Adventist Perspectives. Berrien Springs: Andrews University Press, 1985.

Reardon, Bernard. Religion in the Age of Romanticism. Cambridge, England: Cambridge University Press, 1985.

Rock, Calvin. "Tolerating Celebration." Adventist Review, 10 June 1993, 11.

Ross, Terry S. "Devotion or Deception? Revival and Reformation." Adventist Heritage Center, James White Library, Andrews University, Berrien Springs, MI. 
- "Take a Bow (Applause)." Adventist Heritage Center, James White Library, Andrews University, Berrien Springs, MI.

Russell, Gary E. "Baby Boomers and the Adventist Church." Ministry, July 1992, 14-16.

Sahlin, Monte. Sharing Our Faith with Friends without Losing Either. Hagerstown, MD: Review \& Herald, 1990.

Sahlin, Monte, Carole Luke Kilcher, and Paul Richardson. "What Does the Public Think of Us?" Adventist Review, February 1995, 18-20.

Schaeffer, Francis. The New Spirituality. Downers Grove, IL: InterVarsity Press, 1972.

Schaller, Lyle. It's a Different World. Nashville: Abingdon, 1987.

Schwisow, Ed. "Time to Celebrate a Truce." North Pacific Union Gleaner, 19 August 1991, 2.

Shames, Laurence. The Hunger for More. New York: Times Books, 1989.

Sidey, Kenneth H. "Boomer Boom and Bust: Baby Boom Generation and Religion." Christianity Today, 16 August 1993, 14-15.

Snyder, Dave. A Fresh Breeze Blowing. Portland, OR: Milwaukie Seventh-day Adventist Church, n.d.

Snyder, Howard. Liberating the Church. Downers Grove: Intervarsity Press, 1983.

Snyder, Howard A., and Daniel V. Runyon. Foresight: Ten Major Trends That Will Dramatically Affect the Future of Christians and the Church. Nashville: Nelson Pub., 1986 .

Snyder, Ross. Contemporary Celebration. Nashville: Abingdon Press, 1971.

Solorzano, Lucia. "Helping Kids Learn-Their Own Way. Understanding Different Ways of Learning." U.S. News \& World Report, 31 August 1987, 62. 
Standish, Colin D., and Russell R. Standish. Deceptions of the New Theology. Rapidan, VA: Hartland Publishing, 1989 .

- Keepers of the Faith. Rapidan, VA: Hartland Publishing, 1988 .

Stark, Rodney, and William Simps Bainbridge. The Future of Religion: Secularization, Revival, and Cult Formation. Berkeley, CA: University of California Press, 1985.

Steinke, Peter L. How Your Church Family Works: Understanding Congregations as Emotional Systems. Bethesda, MD: Alban Institute, 1993.

Stenbakken, Erik. "It's Quiet Out Here." Adventist Review, 30 October 1997, 2-3.

Stevenson, Howard. "Architect of Worship: How to Design a Service of Structure, Openness, and Beauty." Leadership, Winter 1996, 103-106.

Stewart, Thomas A. "Turning Around the Lord's Business; Mainline Churches are Losing Members, but Smart Pastors Know How to Call Home the Wondering Lambs." Fortune, 25 September 1989, 116-120.

Strobel, Lee. Inside the Mind of Unchurched Harry \& Mary. Grand Rapids: Zondervan, 1993.

Strunk, Gary D. "Reaching the Secular Mind Through Health Ministry." Ministry, November 1997, 20-21, 29.

Tapia, Andres. "Reaching the First Post-Christian Generation X." Christianity Today, 12 September 1994, 18-23.

Taylor, Greg. "Worship: The Heart of the Church." Ministry, October 1996, 6-8.

Tibbits, Dick. "The Crisis in the Congregation." Ministry, September 1996, 10-13.

Toffler, Alvin. Powershift: Knowledge, Wealth, and Violence at the Edge of the $21^{\text {st }}$ Century. New York: Bantam Books, 1990 .

- The Third Wave. New York: William Morrow, 1980.

Tomlinson, Michael. "Contemporary Christian Music Is Christian Music." Ministry, September 1996, 26-27. 
Towns, Elmer L. An Inside Look at 10 of Today's Most Innovative Churches. Ventura, CA: Regal Books, 1990.

Trueheart, Charles. "Welcome to the Next Church." The Atlantic Monthly Company, August 1996, 37-58.

Tyner, Stuart. "Live to Worship, Worship to Live." Adventist Review, 20 February 1997, 11-12.

"Wahroonga Launches Worship Initiative." South Pacific Division Record, 25 May 1991, 13.

Wall, James, M. "Spiritual Changes: Clinton's Bully Pulpit." The Christian Century, 5 January 1994, 3-4.

Warren, Rick. The Purpose Driven Church: Growth Without Compromising Your Message and Mission. Grand Rapids: Zondervan, 1995.

Webber, Martin. "Give Praise a Chance." Manuscript. Adventist Heritage Center, Andrews University, Berrien Springs, MI.

Webber, Robert. Worship Is a Verb: A Modern Class on Spiritual Renewal, Revised and Updated for the 1990's. Nashville: Abott Martyn, 1992.

Wells, David F. God in the Wasteland: The Reality of Truth in a World of Fading Dreams. Grand Rapids: Eerdmans, 1994 .

White, Ellen G. The Acts of the Apostles. Mountain View, CA: Pacific Press, 1911.

- Christian Service. Hagerstown, MD: Review and Herald, 1925.

- "Christ's Commission." Second Advent Review and Sabbath Herald, 10 June 1880, par. 5.

- Counsels on Health. Mountain View, CA: Pacific Press, 1923.

- Counsels on Sabbath School Work. Washington, DC: Review and Herald, 1938.

- The Desire of Ages. Mountain View, CA: Pacific Press, 1898 . 

1946 .

- Evangelism. Washington, DC: Review and Herald,

- The Ministry of Healing. Mountain View, CA:

Pacific Press, 1905.

- Our High Calling. Washington, DC: Review and Herald, 1961.

- Patriarchs and Prophets. Washington, DC: Review and Herald, 1890.

- Prophets and Kings. Mountain View, CA: Pacific Press, 1917.

- The Publishing Ministry. Hagerstown, MD: Review and Herald, 1983.

- Selected Messages. Vol. 1. Washington, DC: Review and Herald, 1958.

- Sons and Daughters of God. Washington, DC: Review and Herald, 1955.

- Testimonies for the Church. 9 vols. Mountain View, CA: Pacific Press, 1948.

- This Day With God. Washington, DC: Review and Herald, 1979.

- The Upward Look. Washington, DC: Review and Herald, 1982 .

White, James F. A Brief History of Christian Worship. Nashville: Abingdon Press, 1993.

Widmer, Myron. "Adventist Worship--Celebration-Style." Adventist Review, 1 November 1990, 12-16.

Wilson, Bryan R. Religion in Secular Society. Baltimore: Penguin Books, 1969.

Wood, Ralph. "The Fallacy of 'Getting Something out of Worship." Ministry, February 1998, 5-7. 